\title{
FATORES QUE INFLUENCIAM NA COLETA DE PÓLEN POR Apis mellifera L. E ANÁLISES FÍSICO-QUÍMICAS DO PÓLEN COLETADO
}

\section{VANDERLEI DONISETI ACASSIO DOS REIS}

Engenheiro Agrônomo

Orientador: Prof. Dr. LUÍS CARLOS MARCHINI

Dissettação apresentada à Escola Superior de Agricultura "Luiz de Queiroz", Universidade de São Paulo, para obtenção do título de Mestre em Ciências, Área de Concentração: Entomologia.

P I R A C I C A B A

Estado de São Paulo - Brasil

Dezembro - 2000 
Dados Internacionais de Catalogaçāo na Publicação (CIP)

DIVISÃO DE BIBLIOTECA E DOCUMENTAÇÃO - Campus "Luiz de Oueiroz"/USP

\section{Reis, Vanderlei Doniseti Acassio dos}

Fatores que influenciam na coleta de pólen por Apis mellifera L. e análises fisicoquímicas do pólen coletado / Vanderlei Doniseti Acassio dos Reis. - - Piracicaba, 2000.

$76 \mathrm{p}$.

Dissertação (mestrado) - - Escola Superior de Agricultura Luiz de Queiroz, 2000: Bibliografia.

1. Abelha-africanizada 2. Análise fisico-química 3. Biologia animal 4. Coleta de polén 5. Comportamento animal 6 . Inseto útil 7. População animal I. Título

CDD 638.12

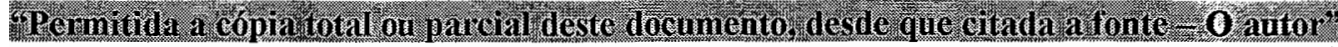


De tanto ver crescer as injustiças

De tanto ver triunfar as nulidades

De tanto ver agigantarem-se os poderes nas mãos dos maus

O Homem chega

A desanimar-se da virtude

A rir-se da honra

A ter vergonha de ser honesto.

Ruy Barbosa. 


\section{AGRADECIMENTOS}

A Deus por estar sempre ao meu lado e iluminar meu caminho.

A Luiz Vicente de Souza Queiroz cujo sonho de outrora tornou-se uma Gloriosa Realidade e a todos que mantêm esse Ideal Vivo.

Ao Prof. Dr. Luís Carlos Marchini, pelas oportunidades oferecidas e ensinamentos transmitidos no decorrer dos Cursos de Graduação e Pós-Graduação.

A todos os Professores e demais Funcionários da ESALQ/USP que muito contribuíram para a minha formação profissional e pessoal, destacando-se os Professores e Funcionários do Curso de Pós-Graduação em Entomologia da ESALQ/USP. Agradecimentos especiais aos Profs. Dr Evôneo Berti Filho, pela correção do summary, e Dr. Gilberto Casadei de Baptista e a equipe do "Laboratório de Toxicologia" (aos Técnicos de Laboratório: Carlos E. Longatti ("Carlão") e Luís R. Sesso; aos Engenheiros Agrônomos: Eduardo Sgarbiero e Luiz P. Trevisan; ao Engenheiro Químico: Oscar Bahia Filho) pelos auxílios prestados nas análises de lipídios do pólen.

Ao Professor Jorge Horii do Departamento de Agroindústria, Alimentos e Nutrição da ESALQ/USP e a equipe do "Laboratório de Açúcar e Álcool" (aos Técnicos de Laboratório: Sylvino L. Torrezan e Rosemary L. da Silva; aos Engenheiros Agrônomos: Antonio S. Baptista, André E. S. Belluco e Solange A. G. Groppo; à Engenheira de Alimentos: Mariana de Paula Eduardo) pelos auxílios prestados nas análises de açúcares do pólen.

Ao Técnico de Laboratório Luís Lucatti ("Cometa") do Setor de Bioquímica do Departamento de Ciências Biológicas da ESALQ/USP, pelos auxílios prestados nas 
análises de açúcares do pólen, no esclarecimento de diversas dúvidas que surgiram ao longo das análises físico-químicas realizadas e acima de tudo por sua grande boa vontade.

Aos Professores do Departamento de Ciências Exatas da ESALQ/USP: Profa. Dr. Maria Cristina Stolf Nogueira e Dr. José Eduardo Corrente e a Doutoranda Denise Garcia de Santana pelos auxílios prestados nas escolhas dos delineamentos experimentais mais adequados e nas análises estatísticas dos resultados.

À Fundação de Amparo à Pesquisa do Estado de São Paulo - FAPESP (Processo: 1998/05017-7), pela concessão da bolsa de estudos para a execução deste trabalho.

Aos meus pais (Benedito e Vera), a minha irmã (Valéria), ao meu avô materno (Benedito - in memoriam) e a minha tia Zeneide pelo exemplo de vida e honestidade. Por estarem sempre ao meu lado em todos os momentos da minha vida e principalmente pelo amor incondicional destes em relação a mim.

Aos amigos Esveraldo, Fritz, Ismael e Olímpio e também as demais pessoas que me incentivaram para que continuasse com a minha formação acadêmica ao longo de todos esses anos.

Aos colegas do Curso de Pós-Graduação em Entomologia pela amizade e companheirismo.

À Dra. Augusta Carolina de C. C. Moreti, do Instituto de Zootecnia (Nova Odessa, São Paulo) pelo apoio e colaboração ao longo de todos esses anos. 
Aos Amigos do Laboratório de "Insetos Úteis" pelo agradável convívio nesses anos, em especial aos casais Sérgio e Andreia Rodrigues; Nilton e Marta Bellizzi; Carlos Alfredo L. de Carvalho; Fábio L. Simões; Geni da Silva Sodré; Gleuber M. Teixeira; Miguel A. R. Diaz-Villalba; Odinete Murari; Patrícia C. F. de Oliveira e Sônia S. Komatsu. Aos Técnicos de Apicultuira: Leonardo L. Baumgratz e Vítor C. da Silva pelos auxílios prestados e pela troca de informações a respeito de como devem ser executados os trabalhos com abelhas, em especial ao primeiro.

Às bibliotecárias da Prefeitura do Campus de Piracicaba da ESALQ/USP pela correção das referências bibliográficas, em particular à Eliana Maria Garcia.

A todos aqueles que direta ou indiretamente colaboraram para a execução deste trabalho. 


\section{SUMÁRIO}

Página

RESUMO

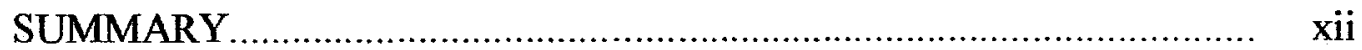

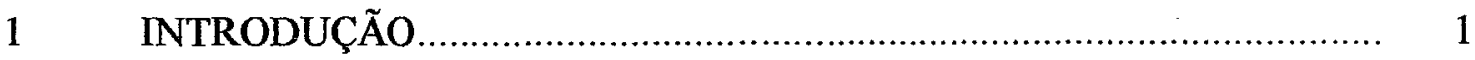

2 REVISÃO DE LITERATURA ............................................................. 3

2.1 Origem das abelhas africanizadas.......................................................... 3

$2.2 \quad$ Origem das castas......................................................................... 4

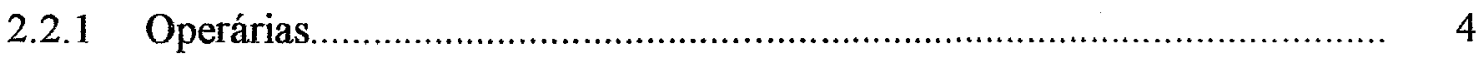

2.2.2 Rainhas

2.2.3 Zangões.................................................................................

$2.3 \quad$ Hábito alimentar das abelhas.................................................................. 7

$2.4 \quad$ Valor nutritivo do pólen para $A$. mellifera …........................................... 9

$2.5 \quad$ Plantas fontes de pólen.................................................................. 12

2.6 Fatores que influenciam na quantidade de pólen coletado por $A$. mellifera 13

2.7 Composição do pólen......................................................................... 17

2.8 Necessidades de pólen por A. mellifera ..................................................... 20

2.9 Coletores de pólen........................................................................ 22

3 MATERIAL E MÉTODOS .............................................................. 25

3.1 Áreas com posturas, crias, pólen e mel em colméias................................ 26

3.2 Eficiência do coletor de pólen de alvado ............................................... 26

3.3 Atividade de coleta de pólen................................................................. 26

3.4 Influência do estado da colméia na atividade de coleta de pólen............... 27

3.5 Média semanal de pólen coletado por A. mellifera .................................... 27

3.6 Pólen coletado para as análises físico-químicas....................................... 27

$3.7 \quad$ Análises fisico-químicas do pólen.......................................................... 28

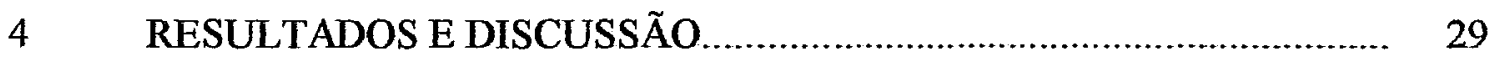




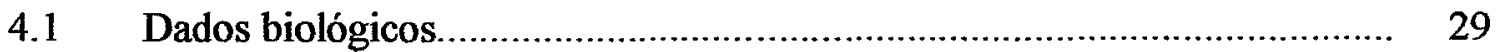

4.1.1 Áreas com ovos de A. mellifera ............................................................... 29

4.1.2 Áreas com crias desoperculadas que darão origem as operárias de $A$. 31 mellifera.

4.1.3 Áreas com crias operculadas que darão origem as operárias de $A .32$ mellifera.

4.1.4 Áreas com óvulos de $A$. mellifera .............................................................. 33

4.1.5 Áreas com crias desoperculadas que darão origem aos zangões de $A$. 34 mellifera..

4.1.6 Áreas com crias operculadas que darão origem aos zangões de $A .35$ mellifera.

4.1.7 Áreas com pólen em colméias de A. mellifera …….................................. 36

4.1.8 Áreas com mel de A. mellifera em colméias.............................................. 37

4.2 Análises fisico-químicas............................................................... 38

4.2.1 Porcentagens (\%) de proteína em amostras do pólen coletado por $A$. 38 mellifera..

4.2.2 Porcentagens (\%) de cinzas em amostras do pólen coletado por $A . \quad 40$ mellifera.

4.2.3 Porcentagens (\%) de umidade em amostras do pólen coletado por A. 41 mellifera.

4.2.4 Porcentagens (\%) de resíduo seco em amostras do pólen coletado por $A . \quad 42$ mellifera.

4.2.5 Porcentagens (\%) de lipídios em amostras do pólen coletado por $A .43$ mellifera.

4.2.6 Determinação eletrométrica do $\mathrm{pH}$ em amostras do pólen coletado por $A$. 45 mellifera...

4.2.7 Acidez titulável em amostras do pólen coletado por $A$. 46 mellifera. 
4.2.8 Porcentagens (\%) de açúcares totais em amostras do pólen coletado por A. mellifera.

4.3 Correlações entre os dados biológicos e as análises físico-químicas 48

4.4 Eficiência (\%) do coletor de pólen (chapa com perfurações de 4,00 mm).. 49

4.5 Granulometria (malhas de 0,$106 ; 0,300 ; 0,500 ; 1,00$ e $2,00 \mathrm{~mm} / \mu \mathrm{m}$ ) do 50 pólen coletado por $A$. mellifera.

4.6 A. mellifera transportando grãos de pólen às 8:00h, 11:00h e 16:00h, 52 com ou sem coletores permanentemente instalados.

4.7 Pólen coletado (g) por A. mellifera em colméias com ou sem rainhas e 54 com coletores permanentemente instalados.

4.8 Quantidades (g) de pólen coletado em colméias de A. mellifera com 56 coletores de pólen permanentemente instalados durante 3 meses.

4.9.1 Áreas $\left(\mathrm{cm}^{2}\right)$ com ovos em colméias de $A$. mellifera com coletores de 57 pólen permanentemente instalados durante 3 meses.

4.9.2 Áreas $\left(\mathrm{cm}^{2}\right)$ com crias desoperculadas que darão origem as operárias de 58 em colméias $A$. mellifera com coletores de pólen permanentemente instalados durante 3 meses.

4.9.3 Áreas $\left(\mathrm{cm}^{2}\right)$ com crias operculadas que darão origem as operárias em 59 colméias de $A$. mellifera com coletores de pólen permanentemente instalados durante 3 meses.

4.9.4 Áreas $\left(\mathrm{cm}^{2}\right)$ com pólen em colméias de $A$. mellifera com coletores de 60 pólen permanentemente instalados durante 3 meses.

4.9.5 Áreas $\left(\mathrm{cm}^{2}\right)$ com mel em colméias de $A$. mellifera com coletores de pólen 61 permanentemente instalados durante 3 meses. 


\title{
FATORES QUE INFLUENCIAM NA COLETA DE PÓLEN POR Apis mellifera L. E ANÁlises FÍSICO-QUíMICAS do PÓLEN COLETADO
}

\author{
Autor: Vanderlei Doniseti Acassio Dos Reis \\ Orientador: Prof. Dr. Luís Carlos Marchini
}

\section{RESUMO}

Foram utilizadas colméias de abelhas africanizadas com coletores de pólen de alvado (frontais) com orifícios de 4,00 $\mathrm{mm}$ de diâmetro. Avaliou-se a eficiência do coletor, a composição química do pólen e o efeito da permanência ou não do coletor no desenvolvimento biológico da abelha. Para as áreas de crias e alimentos, em colméias com coletores permanentemente instalados, ocorreram variações estatisticamente significativas para as áreas de ovos e pólen, não ocorreram variações estatisticamente significativas para as áreas de crias desoperculadas e operculadas que darão origem as operárias e mel, já as áreas de óvulos e crias que darão origem a zangões não foram analisadas devido à sua sazonalidade. As atividades de coleta de pólen às 11:00 e 8:00h (média de 4,16 e 3,64 abelhas transportando pólen, respectivamente) foram estatisticamente semelhantes e superiores ao valor observado às 16:00h (média de 1,36 abelhas transportando pólen). A eficiência média dos coletores de pólen foi $68,23 \% \mathrm{e}$ decrescente com o passar do tempo, sendo $82,5 \%$ na primeira observação e 59,0 \% na última. Para as análises físico-químicas foram obtidos as seguintes médias: $21,38 \%$ de proteínas; $2,87 \%$ de cinzas; $23,65 \%$ de umidade; $76,35 \%$ de resíduo seco; $3,57 \%$ de 
lipídios; $28,44 \%$ de açúcares totais; $20,66 \mathrm{mEq} / \mathrm{kg}$ de pólen de acidez titulável e pH igual a 5,08 . 
FACTORS AFFETING POLLEN COLLECTION BY Apis mellifera L. (HYMENOPTERA: APIDAE) AND PHYSICOCHEMICAL ANALYSIS OF THE COLLECTED POLLEN.

Author: Vanderlei Doniseti Acassio Dos Reis Adviser: Prof. Dr. Luís Carlos Marchini

\section{SUMMARY}

Hives of Africanized honeybees with pollen traps of $4.00 \mathrm{~mm}$ frontal holes were used in this research to evaluated trap efficiency, pollen composition and effect of the permanence or temporary trap in the biological development of the honeybee. Concerning hives with permanent traps one observed statistically significant variations in the areas of eggs and pollen, but not statistically significant ones in the areas of unsealed offsprings and sealed offsprings (workers and honey). Areas of ova which give rise to drones were not analysed due to their seasonability. The pollen collecting activities at $8 \mathrm{a} . \mathrm{m}$. and $11 \mathrm{a.m}$. (average of 3.64 and 4.16 bees transporting pollen, respectively) were statistically similar and higler than the value observed at 4 p.m. (average of 1.36 bees transporting pollen). The mean efficiency of the pollen traps was $68.23 \%$, decreasing with the time being, $82.5 \%$ in the first observation and $59.0 \%$ in the last one. As to the physicochemical analysis the following mean values were obtained: $21.38 \%$ of proteins; $2.87 \%$ of ashes; $23.65 \%$ of humidity; $76.35 \%$ of dry residues; 
$3.57 \%$ of fat; $28.44 \%$ of total sugars; $20.66 \%$ of $\mathrm{mEq} / \mathrm{kg}$ of titratable acidity and $\mathrm{pH}$ of 5.08 . 


\section{INTRODUÇÃO}

O pólen é encontrado na forma de grãos microscópicos contidos nas anteras dos estames florais, são coletados e agrupados para serem transportados pelas abelhas para a colméia em suas corbículas. Além de sua vital intervenção no processo de fecundação das flores e na alimentação das abelhas, tem múltiplas aplicações: cosmética, alimentação humana e de animais domésticos, farmacologia (no estudo e no tratamento de pessoas alérgicas), monitoramento de poluição ambiental, programas de melhoramento de plantas, entre outras (Crane, 1990; Ochoa, 1980).

A composição do pólen varia de acordo com a origem botânica. $\mathrm{O}$ pólen supre as abelhas com aminoácidos e vitaminas essenciais para o seu desenvolvimento; para operárias, este inclui o pleno desenvolvimento de suas glândulas hipofaringeanas e de veneno (Crane, 1990).

As abelhas agrupam o pólen em bolotas, levam para as colméias e armazenam em alvéolos separadamente do mel, utilizando-o para a sua alimentação e a da cria. Por outro lado, coletando o néctar das flores, involuntariamente coletam, também, o pólen, sendo este regurgitado juntamente com o néctar nos alvéolos melíferos. Desta maneira o pólen aparecerá no mel, constituindo-se um importante indicador da sua origem botânica e geográfica (Barth, 1989).

Todas as espécies de Apis coletam néctar e pólen além das necessidades imediatas da colméia. O pólen não consumido é armazenado o que lhes permite sobreviver no período de escassez (Free, 1967).

Tendo em vista a crescente importância da apicultura como atividade econômica fornecedora de alimentos (produzindo mel, geléia real e pólen para o consumo humano) 
e a abelha ( $A$. mellifera) o principal agente polinizador de várias culturas de importância agrícola, torna-se imperioso e fundamental ter conhecimentos aprofundados referentes ao manejo de colméias, que influem tanto na produção desses produtos apicolas, como na produção agrícola.

O principal motivo pelo qual as abelhas têm recebido tanta atenção é sem dúvida alguma sua notável organização social e seu complexo comportamento. As atividades de muitos indivíduos dentro da colônia de Apis estão controladas e coordenadas de tal forma que o funcionamento da colônia como um todo se adapta a seu ambiente em mudança permanente (Free, 1980).

A presença ou ausência de cria jovem, a utilização constante ou não de coletores de pólen, a eficiência na coleta e a existência ou não de rainha na colméia são fatores que podem determinar a quantidade de pólen coletado pelas operárias. Portanto, a determinação destes parâmetros é de vital importância para o manejo adequado das colméias de abelhas africanizadas na coleta de pólen.

No presente trabalho foram estudados parâmetros considerados vitais ao manejo de colméias de abelhas africanizadas utilizadas na coleta de pólen: correlação do desenvolvimento populacional da colméia com a coleta de pólen; avaliação dos prováveis mecanismos de compensação usados pelas abelhas contra o anteparo do coletor de pólen; coleta de pólen em função da presença ou ausência da rainha; análises físico-químicas do pólen coletado; correlação da composição do pólen com o desenvolvimento biológico da colméia. 


\section{REVISÃo DE LITERATURA}

\subsection{Origem das abelhas africanizadas}

As abelhas Apis são originárias do Velho Mundo. Ocorrem principalmente nas faixas intertropicais, mas a $A$. mellifera avança bastante sobre as regiões temperadas. Algumas subespécies foram introduzidas no Brasil, provenientes da Europa e do continente africano. Atualmente, supõe-se que a maioria dos enxames naturais sejam formas híbridas - as chamadas abelhas africanizadas (Imperatriz-Fonseca et al., 1993). Já Akatsu \& Pegoraro (2000) afirmaram que devido aos cruzamentos múltiplos das rainhas com zangões, verifica-se variação morfológica (caracteres africanos e europeus) em indivíduos de uma mesma colônia.

A distribuição bem sucedida de $A$. mellifera deve-se muito à habilidade da colônia de se ajustar a mudanças sazonais e de exercer um controle considerável sobre seu meio físico interno. Durante os periodos de escassez, quando não há coleta, a colônia pode sobreviver com o alimento armazenado em seus favos. Sob tais condições há pouca cria e a colônia pode consistir somente de um agrupamento de rainha e operárias. Entretanto, com a chegada de uma estação mais favorável, mais prole é criada, o número de operárias aumenta, a criação de zangões começa, novas rainhas podem ser criadas e a colônia pode se reproduzir por enxameagem (Free, 1980).

Devido ao fato da abelha africanizada ter uma enxameação maior que as abelhas européias facilitou a sua propagação. 


\subsection{Origem das castas}

Como em outros himenópteros, a abelha melífera apresenta quatro estágios: ovo, larva, pupa e adulto; com o período de duração variável entre castas. Há também variações entre as subespécies de $A$. mellifera, espécies deste gênero e a dieta fornecida para cada uma delas (Crane, 1990).

O processo de crescimento e metamorfose nas abelhas envolve algumas das mais complexas interações em uma colônia de insetos sociais. As 3 castas das abelhas meliferas têm algumas demandas nutricionais diferentes e mecanismos para satisfazer seus requerimentos alimentares, como fazem os estágios larval e adulto dentro de cada uma das 3 castas. Entretanto os materiais que iniciam e mantêm a nutrição para as crias e abelhas adultas, quer operárias, rainhas, ou zangões, são os mesmos: néctar e pólen. Estes dois produtos florais fornecem toda a alimentação necessária para o crescimento larval, metamorfose, desenvolvimento e funções adultas. Basicamente, o néctar fornece

carboidratos na forma de açúcares, e o pólen fomece proteína, lipídios, vitaminas e minerais. A abelha melífera tem vários mecanismos evolutivos para o preparo do néctar e do pólen. Assim que o alimento é fornecido para cada um dos estágios e castas, são adequadamente adaptados para suas necessidades (Winston, 1987).

\subsubsection{Operárias}

O embrião desenvolve-se por meio da absorção do vitelo do ovo, o qual é uma fonte rica em proteínas. A larva que emerge do ovo é alimentada dentro do alvéolo pelas abelhas nutrizes (jovens operárias adultas). As operárias desenvolvem-se em células horizontais (alvéolos), a partir de óvulos que foram fecundados com espermatozóides armazenados na espermateca da rainha formando o ovo. A área de cria está localizada na parte mais central da colméia, onde ocorrem condições de maior proteção e regulação térmica em função do agrupamento de abelhas. A larva da operária apresenta um regime intensivo de alimentação proporcionando nos 5 dias após a sua eclosão um acréscimo de 
2.000 vezes ao seu peso inicial. Na primeira semana após a emergência do adulto o ganho de peso é máximo, especialmente devido a alimentação polínica fornecida (Winston, 1987).

As larvas são alimentadas freqüentemente pelas abelhas nutrizes com alimento de cria secretado pelas glândulas hipofaringeanas e mandibulares. $O$ alimento de cria apresenta elevada composição de proteínas, contém vitaminas e outros nutrientes que as larvas requerem. Os nutrientes no alimento de cria são derivados, na sua maior parte, do pólen consumido pelas abelhas nutrizes. Larvas de operárias são alimentadas no primeiro dia com "geléia de operária" a qual é relativamente pobre em açúcares. Depois, no segundo para o terceiro dia, as larvas têm o alimento mudado para "geléia de operária modificada", com algum mel e pólen. No terceiro e quarto dias foram encontrados alimentos contendo $47 \%$ de açúcar. A alimentação da larva é suspensa quando ela tem aproximadamente 5 dias de idade, $\mathrm{e}$ as operárias constroem uma capa de cera que vedará as células. Diferentemente da larva da rainha, a larva da operária é enclausurada sem qualquer alimento. As larvas totalmente crescidas secretam fibras de seda para formar seus casulos (Prost, 1981).

O metabolismo do alimento pelas larvas gera calor, mas durante o estágio pupal a manutenção do controle da temperatura em $35^{\circ} \mathrm{C}$ é inteiramente dependente do número de abelhas cobrindo o favo (Koeniger \& Veith, 1984).

Perto do momento da emergência da operária as estruturas anatômicas adultas são definidas e fixadas, entretanto o conteúdo protéico do adulto depende da disponibilidade de alimento fornecido na fase larval (Crailsheim, 1990). No entanto, segundo Winston (1987), o pleno desenvolvimento dos sistemas glandular e reprodutivo (atrofiado em relação ao da rainha) ocorre posteriormente, e depende de uma elevada entrada de proteína e outras substâncias alimentares não-energéticas, obtidas do pólen. $O$ mesmo procedimento ocorre para rainhas e zangões.

Durante os primeiros dias da vida adulta, uma operária necessita ingerir uma quantidade adequada de pólen de boa qualidade, objetivando que diferentes glândulas desenvolvam o seu pleno potencial para produção de secreções específicas. Operárias 
começam a ingerir pólen desde que emergem do alvéolo. O consumo de pólen pelas jovens operárias adultas eleva-se a um máximo ao redor do quinto dia, e decresce do oitavo ao décimo dia. $\mathrm{O}$ pólen é digerido por meio de enzimas produzidas no ventrículo. Até cerca de 5 dias de idade as glândulas hipofaringeanas na cabeça secretam alimento de cria, que continua até as glândulas começarem a degenerar próximo ao décimo dia (Winston, 1987).

Muitas atividades das operárias dentro da colméia ou ninho são sociais e dependentes do estágio de desenvolvimento de seus vários sistemas glandulares, da sua idade, e de fatores que dependem da condição e circunstâncias da sua colônia (Prost, 1981).

\subsubsection{Rainhas}

Rainhas, de forma semelhante às operárias, desenvolvem-se de ovos. Elas tornam-se rainhas como resultado da dieta diferenciada secretada e depositada nas células pelas abelhas nutrizes; estas abelhas ajustam o conteúdo de água do alimento para larvas diferentes, e assim regulam sua composição. Alimento larval de operária contem somente $12 \%$ de açúcar no primeiro dia, aumentando no segundo dia, ao passo que o alimento de uma larva de rainha contêm muito açúcar (34\%) durante o período de 1 a 4 dias (Shuel \& Dixon, 1959). Esta alta concentração de açúcar estimula a larva a ingerir mais do alimento, o qual é fornecido em excesso. A célula é então operculada com um suprimento de alimento no seu interior, e a larva continua alimentando-se. Dietz \& Lambremont (1970) encontraram que larvas, as quais originarão rainhas, consomem, durante o seu desenvolvimento, $25 \%$ mais alimento do que as larvas que darão origem às operárias. Órgãos sensoriais nas peças bucais da larva de rainha, contêm quimioreceptores que reagem somente a açúcares; não tem sido encontrada reação para qualquer outro componente do alimento larval. Traços de pólen também têm sido encontrados no alimento das larvas de rainhas (Ribbands, 1953; citado por Crane, 1990). 


\subsubsection{Zangões}

Zangões desenvolvem-se de óvulos postos pela rainha em células de zangão. Estas células são operculadas após 7 dias. As larvas crescem grandemente, e recebem muito mais alimento, do que larvas de operária, com valores de $384 \mathrm{mg}$ e $159 \mathrm{mg}$, respectivamente (Haydak, 1970).

O conhecimento a respeito do alimento fornecido para larvas de zangão é menor do que para operárias ou rainhas. A "geléia de zangão" fornecida para larvas do primeiro até o terceiro dia de idade é conhecida por diferir em vários aspectos da geléia das operárias ou da geléia real. Matsuka et al. (1973) demonstraram que "geléia modificada de zangão" fornecida do quinto ao sexto dias tinha a composição aproximada de 2 partes de geléia de zangão e 1 parte de mel com 15.000 carga de pólen por mg do alimento.

Segundo Haydak (1970) o conteúdo de açúcar no alimento larval seria de $75 \%$ e $24,9 \%$ nas idades de 1 a 2 dias e 3 a 5 dias, respectivamente.

A taxa de mortalidade é muito alta entre larvas de zangão, diferentemente do que ocorre com as larvas de operárias (Winston, 1987).

Szolderits \& Crailsheim (1993) verificaram em A. mellifera carnica que os zangões consomem pólen durante os seus 5 primeiros dias da fase adulta (sendo máxima a atividade proteolítica entre o terceiro e o quarto dia) e após iniciarem o vôo o consumo é insignificante. Comparando-os com as operárias no que se refere à atividade proteolítica, o consumo e a digestão do pólen pelos zangões é menor.

\subsection{Hábito alimentar das abelhas}

Naturalistas notaram que algumas espécies visitavam um ou poucos tipos de flores, enquanto outras obtinham alimentos em vários tipos (Imperatriz-Fonseca et al., 1993). As abelhas $A$. mellifera são classificadas, segundo Loew, como politróficas, ou seja, fazem uso de uma grande diversidade de flores, possuindo assim hábito alimentar 
generalista. Quanto a coleta de pólen, Grant (1950) classifica as abelhas como polilécticas, por utilizarem várias espécies vegetais como fonte de pólen e néctar.

Há muitos fatores que influenciam a coleta de alimento pelas abelhas sociais, como o comportamento das campeiras, as necessidades coloniais (tamanho das colônias), o sistema de comunicação, etc. A abundância relativa das espécies vegetais numa área e a discriminação dos caracteres florais (estrutura forma $_{2}$ cor e odor) influem na localização do alimento e, em alguns casos, na preferência alimentar (ImperatrizFonseca et al., 1993; Loken, 1981; Michener et al., 1978).

$\mathrm{Na}$ escolha estão relacionados a morfologia e o comportamento das abelhas. As estruturas de coleta e transporte de pólen e néctar diferem, principalmente, nos grandes grupos de abelhas. Todas as abelhas da família Apidae apresentam corbícula, não sendo "efetivas" nas rainhas e nos gêneros parasitas. É uma das estruturas mais versáteis para o transporte do pólen. A corbícula resultou de modificações na tíbia do terceiro par de pernas, que se tornou muito larga e ligeiramente côncava na face externa, com pêlos de comprimento e formas variáveis dispostos à sua margem. A tíbia adquiriu alguma semelhança com uma cesta, onde o pólen é armazenado em forma de bolotas. As Apidae também têm o hábito de acrescentar néctar ou mel ao pólen antes de acondicioná-lo na corbícula. Esse comportamento assegura a coleta e o transporte de diferentes tipos de carga de pólen (Thorp, 1979).

O pólen coletado pelas abelhas chega de espécies de plantas selecionadas por elas. Contém açúcar adicional derivado do mel ou néctar com o qual as abelhas umedecem o pólen quando embalam-no nas "cargas de pólen" em suas pernas posteriores (Crane, 1990).

Algumas abelhas obtêm fácil e rapidamente o alimento em flores com estruturas elaboradas, onde o pólen e o néctar são de difícil acesso. Outras são capazes de aprendizagem na manipulação das peças florais $\mathrm{e}$, gradualmente, tornam-se coletoras eficientes. Em todos esses aspectos as abelhas sociais da família Apidae se destacam (Imperatriz-Fonseca et al., 1993). 
A origem da planta pode, freqüentemente, ser identificada pela cor e forma do grão do pólen que variam em relação à espécie vegetal da qual procedem (Ochoa, 1980).

Quando as abelhas visitam muitas flores de uma espécie a cor da carga de pólen é uniforme. Ocasionalmente uma abelha coleta pólen em mais de uma espécie resultando assim em uma "cor mista" da bolota. Somente $0,1 \%$ de todo pólen coletado é misto. Dois tipos mistos de massa são encontrados: "M" e o "S". No tipo "M", grãos de duas ou mais espécies são misturados na corbícula, resultando em um grão uniforme, e algumas vezes até mesmo uma nova cor. No " $\mathrm{S}$ " ou segregado, bolotas de pólen apresentam cores diferentes, resultando em bolotas listradas (Schwan \& Martinovs, 1954; citados por Stanley \& Linskens, 1974).

\subsection{Valor nutritivo do pólen para $\boldsymbol{A}$. mellifera}

Duas linhas de pesquisa têm sido utilizadas para determinar o valor nutritivo do pólen. Na primeira os pesquisadores determinam os nutrientes essenciais para $A$. mellifera presentes no pólen sem levar em consideração a sua digestibilidade (Vivino \& Palmer, 1944). Na Segunda, além de determinarem a sua composição química, levam em consideração a digestibilidade de pólens de origens específicas utilizados na dieta de A. mellifera e avaliam diversas características do crescimento e desenvolvimento da abelha melifera (Haydak, 1970).

Todos os aminoácidos, lipídios, esteróis, minerais e vitaminas que a abelha melífera (A. mellifera L.) necessita para sobreviver são fornecidos pelo pólen da sua dieta (Dietz, 1975).

Para muitos insetos, e especialmente abelhas, o pólen é a principal fonte da alimentação não-líquida. Ele contém os nutrientes essenciais para produção da geléia real, a qual é o alimento da rainha e da forma jovem da operária, e é também a fonte fundamental de proteína e lipídios para as larvas de abelhas (Apis) e supõem-se de outras espécies e gêneros de Apidae. A soma de proteína e lipídios no néctar é insignificante, portanto, as operárias usam proteina diretamente do pólen. Dessa forma, o pólen é 
essencial para o crescimento normal e desenvolvimento individual das abelhas, bem como, na reprodução das colônias (Stanley \& Linskens, 1974).

Logo que o pólen tenha sido levado para a colméia pelas forrageiras, as operárias tratam-no para prevenir a germinação, dando origem ao processo digestivo, e preparando-o para longo período de armazenamento. Um ácido fitocidal é adicionado quando o pólen é colocado no favo, o qual previne a germinação e a atividade deletériça bacteriana. A natureza química desta substância ainda não é conhecida, mas ela aparenta ser produzida nas glândulas hipofaringeanas e/ou mandibulares e é relatado como 10 hidroxi 2 decenóico. Alguma digestão preliminar do pólen também tem lugar como um resultado das enzimas adicionadas pelas abelhas e possivelmente alguma ação bacteriana benéfica. Assim a sucrose é largamente invertida pela invertase adicionada pelas operárias, e o pólen armazenado tem um alto conteúdo de histamina e vitamina $\mathrm{K}$, indicativo da ação bacteriana. As enzimas adicionadas juntamente com o mel quando o pólen é depositado nas células previne o metabolismo anaeróbico e a fermentação, entretanto, quais são as enzimas que contribuem para a longevidade do armazenamento do pólen nas células ainda não são conhecidas. $O$ pólen que sofreu as modificações da armazenagem nos alvéolos é denominado como "pão-de-abelha", desde então está pronto para ser ingerido e digerido por elas (Crane, 1990).

Diferentemente do néctar, o pólen contém uma ampla variedade de nutrientes que suportam o crescimento e desenvolvimento nos organismos vivos. Muitos dos nutrientes que o pélen contêm, e especialmente determinados animoácidos, são essenciais para o desenvolvimento das abelhas melíferas, do ovo até o adulto maduro. As colônias normalmente não armazenam pólen muito além dos seus requerimentos, e a produção de pólen pelas plantas é importante para a atividade das abelhas durante toda a estação (Prost, 1981).

Segundo Schmidt (1985) o pólen contém fagoestimulantes, os quais não são limitados a uma única classe de compostos. 
As abelhas necessitam de pólen para o desenvolvimento de suas crias e quanto maior a disponibilidade de alimento, no caso pólen, mais rápido e eficiente é o período de incubação (Dell'Isola, 1945).

Para seu crescimento e desenvolvimento as abelhas precisam de uma alimentação adequada, com compostos essenciais que lhes proporcionem a estrutura corporal e a energia para o cumprimento de suas atividades. As fontes de onde as abelhas obtém energia, proteínas, vitaminas e minerais são encontradas no néctar, água, mel e pólen. Através desses produtos formam seus componentes dietéticos básicos, além das secreções das glândulas hipofaringeanas e mandibulares das operárias que nutrem as larvas (Haydak, 1970).

O valor protéico do pólen varia de 10 a $36 \%$ e segundo Herbert Jr. et al. (1977) os níveis ótimos para dietas fornecidas a $A$. mellifera produzindo crias estariam situados entre $23 \%$ a $30 \%$. O conteúdo de aminoácidos dependerá da origem botânica e nem todos os tipos de pólen apresentam igual valor nutricional, já que abelhas alimentadas com determinados tipos de pólen desenvolvem-se mais rapidamente que outras. O pólen contém todos os elementos minerais que a abelha utiliza na estruturação dos sistemas enzimáticos de seus processos vitais. Todos os requerimentos são satisfeitos à base do pólen, cujos níveis podem variar com as espécies botânicas (origem floral) e com as condições do solo que nutre as plantas (Kevan \& Baker, 1983; Loper \& Cohen, 1987).

O pólen também contém lipídios (aproximadamente de 1 a $20 \%$, mas usualmente não maior do que 5\%), os quais também são importantes para a nutrição da abelha. Esteróis estão presentes em menores, mas essenciais, quantidades. A maioria dos pólens contém menos do que $0,5 \%$ de esteróis, mas estes são exigidos para o metabolismo das abelhas, visto que, elas não podem sintetizar colesterol sem os precursores obtidos do pólen. Também contém açúcares, vitaminas e minerais, os quais são importantes para a nutrição da abelha. Há uma considerável variabilidade no valor nutritivo dos pólens de diferentes plantas, particularmente por causa das diferentes quantidades de proteína que possuem embora a importância de alguns componentes encontrados no pólen, ainda não são muito bem compreendidos (Winston, 1987). 
Cruz-Landim (1985) sugeriu que a parede da íntina é permeável às enzimas digestivas e aos produtos da digestão, e que somente cerca de $50 \%$ do pólen ingerido é digerido. No entanto, Schmidt \& Buchmann (1985) obtiveram $89 \%$ de digestibilidade aparente do pólen consumido por $A$. mellifera com coeficiente digestibilidade aparente do nitrogênio de $83 \%$, portanto, a abelha melífera digere o pólen e utiliza o nitrogênio de forma eficiente.

Misturas de pólen são mais efetivas do que pólen de uma única espécie. No Arizona, EUA, uma mistura de pólen coletado por abelhas de Populus fremontii, Prosopis velutina e Rubus sp. aumentou grandemente a longevidade das abelhas confinadas (Schmidt et al., 1987).

\subsection{Plantas fontes de pólen}

As plantas superiores que têm flores, as angiospermas, em numerosos casos necessitam de um agente que leve o seu pólen de uma planta a outra, numa mesma planta ou até das anteras ao pistilo da mesma flor. Assim, as abelhas ajudam a fecundar as flores fazendo o processo da polinização (Nogueira-Neto, 1997).

A maioria das angiospermas são polinizadas por insetos, e seu pólen é muito nutritivo para abelhas, no entanto, muitas espécies de plantas possuem deficiências nutricionais (Boelter \& Wilson, 1984), como por exemplo, dente-de-leão (Taraxacum officinale) (Peng et al., 1985) e alfafa (Medicaco sativa) (Motter, 1981). As gimnospermas são polinizadas pelo vento, e seus pólens são menos nutritivos para abelhas, pois contém muito mais fibra bruta (média de $29,2 \%$ ) do que pólens de angiospermas (média de 3,3\%) (Solberg \& Remedios, 1980; citados por Crane, 1990).

Muitas plantas que secretam néctar também produzem simultaneamente pólen. No entanto a produção de pólen pode não acompanhar a secreção de néctar por nectários extraflorais e a produção de "honeydew". As abelhas melíferas também coletam pólen de plantas que não produzem néctar, especialmente culturas agrícolas tais como: arroz, sorgo e milho, as quais produzem muito pólen (Crane, 1990). 


\subsection{Fatores que influenciam na quantidade de pólen coletado por $\boldsymbol{A}$. mellifera}

No geral, as quantidades armazenadas de mel na colônia são muito superiores (cerca de $25 \mathrm{~kg}$ ) aos valores observados para o pólen (cerca de $1 \mathrm{~kg}$ ) (Jeffree \& Allen, 1957).

Free (1980) observou que o número de ovos colocados, quantidade de alimento disponível, quantidade de cria, número de operárias nascidas e número de coletoras disponíveis são fatores determinantes na quantidade de pólen coletado por uma colméia. Já para Neira (1988) as necessidades de alimentos e requerimentos nutritivos de uma colônia de abelhas serão diferentes segundo as estações do ano, o lugar geográfico e a população da colméia em relação a proporção de abelhas jovens, abelhas velhas e crias.

Al-Tikrity et al. (1972) citaram que entre os fatores que alteram a coleta de pólen, além da presença de cria jovem, estão o tamanho da colônia, as diferenças climáticas e topográficas da área e a abundância de plantas forrageiras na vizinhança. Dreller et al. (1999) verificaram que a presença de alvéolos vazios nos quadros, principalmente ao redor das crias, estimulam a coleta de pólen pelas campeiras, pois é nesse local que elas preferencialmente depositam as suas cargas de pólen.

Barker (1971) não encontrou correlação entre a coleta de pólen e o tamanho da população, mas sim, entre a coleta de pólen e a área de cria. Delaplane \& Harbo (1987) avaliaram o efeito da ausência da rainha (colônias órfãs) na sobrevivência das operárias, comportamento defensivo (número de ferrões) e ganho de peso das colméias (entrada de alimentos). Obtiveram para todos os itens decréscimos significativos. Eckert et al. (1994) estudaram o comportamento de coleta de pólen (através das cargas de pólen das campeiras que retornavam) em colônias com grandes áreas de cria $\left(9600 \pm 408 \mathrm{~cm}^{2}\right)$ e com pequenas áreas de cria $\left(1600 \pm 80 \mathrm{~cm}^{2}\right)$. Observaram que as campeiras de colônias com grandes áreas de cria coletavam cargas maiores, no entanto, quanto ao número de abelhas coletoras de pólen não foram verificadas diferenças estatisticamente significativas entre os dois tratamentos. 
Segundo Hellmich II et al. (1985) a abelha melífera pode ter uma alta ou baixa tendência de armazenamento de pólen, sendo que esta característica apresenta alta herdabilidade.

Segundo Louveaux (1958a, b; 1959, citado por Stanley \& Linskens, 1974) a temperatura é o mais importante fator individual da coleta de pólen. Acima de $10^{\circ} \mathrm{C}$, há uma correlação entre temperatura e o pólen coletado e próximo a temperatura crítica $\left(10^{\circ} \mathrm{C}\right)$ a presença ou ausência de cria é importante na limitação da atividade de coleta de pólen. Acima da temperatura crítica, intensidade luminosa pode ser também um fator limitante. A máxima atividade de abelhas ocorre depois que a radiação solar excede 3.600 calorias por centímetro quadrado por hora.

Neumaier \& Lengler (1998a, b) observaram que a temperatura média do ar $\left(23,84^{\circ} \mathrm{C}\right)$ apresentou efeito significativo na produção de pólen do coletor intermediário; a precipitação (471,8 $\mathrm{mm}$ em 28 dias de chuva) apresentou efeito significativo na produção de pólen do coletor de alvado e a umidade relativa do ar média $(75,30 \%)$ apresentou efeito significativo na produção de pólen do coletor intermediário.

Blaschon et al. (1999) verificaram que a quantidade de pólen armazenada aumenta em condições de bom tempo e decrescem quando as condições pioram. No mau tempo o número de larvas "grandes" ( $\geq 140 \mathrm{mg}$ ) decresceram significativamente enquanto que o número das "pequenas" ( $<140 \mathrm{mg}$ ) aumentou consideravelmente; quando as condições do tempo foram boas ocorreu o oposto.

Sobre o comportamento das abelhas com relação à coleta de pólen e néctar, Free (1967) afirmou que elas podem mudar de atividade na coleta de néctar e pólen e viceversa, de acordo com as necessidades da colméia. A proporção de abelhas coletoras de pólen e a quantidade deste, aumenta com a presença de cria.

$O$ raio de vôo das abelhas influencia na diversidade de coleta de alimento, uma vez que as campeiras precisam retornar ao ninho. Embora $A$. mellifera seja capaz de voar a grandes distâncias freqüentemente as abelhas restringem a coleta de alimento às flores situadas num raio de 1 a $2 \mathrm{~km}$ ao redor do ninho o que ajuda no planejamento da produção de mel ou da polinização (Free, 1993). 
A idade na qual as operárias coletam pela primeira vez varia muito (10 a 30 dias de idade); em geral quanto mais precocemente realizam vôos de orientação tanto mais rápido iniciam as coletas pela primeira vez. Quando as operárias se transformam em coletoras, abelhas campeiras ou também chamadas "forrageadoras", suas glândulas hipofaringeanas atrofiam-se, apesar de serem relativamente jovens. Existe pouca variação no tamanho das operárias de Apis (cerca de 80-110 mg em peso), no entanto, as de tamanho maior provavelmente iniciam a coleta em idade mais precoce que as menores (Free, 1980). Já a longevidade das abelhas coletoras, depende dos níveis de proteínas corporais no início da fase coletora (Doull, 1980).

A hora de coleta do pólen varia com as diferentes espécies vegetais e depende primariamente de quando as flores estão abertas. Podem ser enquadradas em 3 categorias de abertura floral que são: manhã, tarde e dia todo (Maurizio, 1953; citada por Stanley \& Linskens, 1974).

As abelhas apresentam ${ }_{2}$ em climas temperados, no começo da primavera, o seu nível populacional mínimo da colônia no ano. No entanto, o aumento dos recursos alimentares disponíveis e a sua entrada de forma crescente na colméia ocasionam um aumento na quantidade de crias. Estas abelhas jovens terão uma longevidade maior como coletoras do que as suas irmãs que iniciaram a estação (Dietz, 1975; House, 1961).

Em regiões onde o clima e a falta de floração não permitem que as abelhas saiam em busca de alimento, causam um esgotamento de suas reservas mais rapidamente. Segundo Dell'Isola (1945), se as abelhas utilizarem todo pólen disponível na colméia para a alimentação das crias não dispõem do alimento para se nutrirem.

A natureza e os aminoácidos são provavelmente dois fatores que impulsionam a abelha melífera a coletar os pólens que satisfaçam as exigências da colméia (Ochoa, 1980). No entanto, Nye \& Mackensen (1970) verificaram que as abelhas meliferas não coletam pólen de alfafa no sudeste de Idaho e sim no nordeste de Utah. Segundo estes autores, as razões para essas diferenças não seriam claras, mas envolveriam, provavelmente, a combinação do efeito do clima nas plantas, o volume de néctar 
secretado, a concentração de açúcar, e a natureza e abundância da competição por fontes de pólen.

Alguns gêneros de abelhas, como Apis, Bombus e Colletes, podem carregar uma carga de pólen de 100 a $200 \mathrm{mg}$, peso esse igual a metade do seu próprio peso corporal. O tamanho e o peso da bolota de pólen carregada por abelhas pode variar de 7,5 $\mathrm{mg}$ até $15 \mathrm{mg}$ dependendo das plantas de origem. Grandes diferenças foram encontradas na carga do pólen colhido de plantas de origens diferentes e também nas quantidades coletadas por colônias vizinhas em alguns apiários (Stanley \& Linskens, 1974). Segundo Funari et al. (1993) as abelhas africanizadas transportam para a colméia uma carga média de $11,4 \mathrm{mg}$, nas duas corbículas, que corresponde à cerca de $17 \%$ do peso da operária coletora.

Alves et al. (1994) relataram que as abelhas recolhem pólen durante o ano todo e que, embora a quantidade de pólen seja bastante variável (desde $18,27 \mathrm{~g}$ até $343,33 \mathrm{~g}$ ) a média geral foi de aproximadamente $60 \mathrm{~g} /$ coleta/dia. Van Ass et al. (2000) obtiveram uma produção média de pólen de $141,43 \pm 135,65 \mathrm{~g}$, sendo que as maiores produções ocorreram em setembro e outubro.

Já Trevisan (1983) relatou que em nosso país há grande abundância de pólen e dificilmente ocorre escassez do produto na colméia, sendo que em alguns casos chega a ser até prejudicial como nos grandes florestamentos de eucaliptos, próximos à cidade de Uberaba (MG), onde a coleta e o armazenamento do pólen é tão grande que chega a ser prejudicial, pois a rainha não encontra favos vazios para a postura. Embora o contrário tenha ocorrido no estado do Piauí onde várias caixas foram abandonadas exclusivamente por carência de pólen.

Alves et al. (1997) avaliaram diferentes tipos de coletores de pólen em colméias de abelhas africanizadas no Brasil durante o período de janeiro de 1992 a dezembro de 1994 (exceto nos dias de chuva), obtendo uma produção média de 45,06 g; 37,20 g e 33,05 g de pólen, respectivamente para os modelos intermediário, de fundo e frontal. Já Echeverry \& Jordan (1989) em coletas realizadas em diferentes meses e regiões brasileiras verificaram uma média de $30 \mathrm{~g}$ utilizando-se coletores frontais. 
Segundo Jaycox (1970) a coleta de pólen não é controlada diretamente pelo feromônio da rainha, como no caso da coleta de néctar. No entanto, Free (1979) verificou o efeito do feromônio de cria afeta a coleta de pólen, pois quando as abelhas entravam na colméia diretamente pela área de cria a quantidade de pólen coletado pelas campeiras era muito maior do que quando entravam pela área onde estão armazenados os alimentos na colméia. Já, Pankiw et al. (1998) observaram que o número de campeiras nos tratamentos com feromônio (extrato de 1.000 larvas) e crias (1.000 larvas) foi semelhante estatisticamente, sendo muito superiores aos valores apresentados nas colônias sem feromônio ou crias. No entanto, quando aplicaram o extrato de 2.000 larvas o número de campeiras foi 2,5 vezes superior ao tratamento com 1.000 larvas (crias). Verificaram também estímulos para a coleta de pólen após 1 hora da aplicação do feromônio.

\subsection{Composição do pólen}

A composição do pólen varia entre espécies de plantas; também sofre a influência da idade, da condição nutricional da planta e das condições ambientais durante o desenvolvimento do pólen (Herbert Jr. \& Shimanuki, 1980).

Segundo Brasil (2000) deve ter os seguintes requisitos físicos-químicos: umidade máximo de $30 \%$; cinzas máximo de $4 \%$; lipídios mínimo de $1,8 \%$; proteínas mínimo de $8 \%$; açúcares totais de $14,5 \%$ a 55,0\%; fibra bruta mínimo de $2 \%$ e pH de 4 a 6.

O pólen demonstra maior diversidade que qualquer outro produto da colméia e segundo Ochoa (1980) e Avila (1980) o pólen espanhol tem, respectivamente: umidade: 12 a $20 \%$; 4\%. Proteínas: 20 a 40\%; 35\%. Carboidratos: 25 a 40\%; 50\%. Lipídios: não determinado; 5\%. Minerais: 1 a 7\%; 6\%. Aminoácidos (ambos os autores): histidina, leucina, isoleucina, triptofano, valina, lisina, metionina, treonina, glutamina, arginina, cistidina, fenilalanina e prolina. Vitaminas (ambos os autores): $A, B_{1}, B_{2}, B_{3}, B_{5}, B_{6}, B_{14}$, $B_{15}, B_{16}, C, D, E, H, K$, e P. 
Vorst et al. (1982) compararam a composição de lipídios do pólen armazenado em laboratório e na colônia de $A$. mellifera na Bélgica. Obtiveram que a concentração de esteróis foi $56 \%$ maior no pólen armazenado na colônia, o mesmo ocorrendo para os ácidos graxos essenciais linoléico e linolênico. Estas variações qualitativas e quantitativas seriam devidas aos seguintes fatores: influências das secreções glandulares das abelhas e do mel adicionado ao pólen; a influência da ação das bactérias no pólen armazenado na colônia e a relativamente mais alta temperatura da colônia $\left(35^{\circ} \mathrm{C}\right) \mathrm{em}$ relação à do laboratório $\left(25^{\circ} \mathrm{C}\right)$.

Day et al. (1990) deterninaram a composição química de diversas plantas (trevo branco, salgueiro, Pinus sp., Rubus sp., kiwi, etc.) utilizadas por $A$. mellifera para a coleta de pólen na Nova Zelândia. A umidade variou de $16,8 \%$ a $25,9 \%$; lipídios de $0,17 \%$ a $13,40 \%$; carboidratos de $12,6 \%$ a $29,6 \%$, sendo o teor de açúcares redutores de $11,1 \%$ a $25,7 \%$ e proteínas de $2,9 \%$ a $23,5 \%$. Concluíram que a maioria das plantas analisadas contém nutrientes suficientes para o crescimento e desenvolvimento da abelha melifera.

Youssef et al. (1978) obtiveram a composição química das principais plantas (trevo egípcio, milho, mostarda selvagem e feijão-fava) utilizadas por $A$. mellifera para a coleta de pólen no Egito. $O$ teor de proteínas foi de $23,3 \%$ a $37,7 \%$; lipídios de $6,2 \%$ a $12,5 \%$; amido de $4,0 \%$ a $18,2 \%$; açúcares redutores de $7,6 \%$ a $13,0 \%$; açúcares não redutores de $0,8 \%$ a $4,5 \%$ e cinzas de $2,7 \%$ a $5,7 \%$; sendo que todos os pólens apresentavam altos teores de $\mathrm{K}, \mathrm{Ca}$ e $\mathrm{Mg}$, moderados teores de $\mathrm{Fe}, \mathrm{Na}$ e $\mathrm{Mn}$, e pequenos valores de $\mathrm{Zn}$ e $\mathrm{Cu}$.

Herbert Jr. \& Shimanuki (1978) verificaram que a composição química do pólen recém coletado por $A$. mellifera e do pão-de-abelha (pólen armazenado na colônia) nos EUA. Para o pólen recém coletado o teor médio foi para umidade $24,3 \%$; matéria seca $75,7 \%$; proteínas $24,1 \%$; lipídios $4,9 \%$; amido $1,8 \%$; açúcares redutores $20,7 \%$; açúcares não redutores $2,1 \%$; cinzas $3,2 \%$; pH 4,8 ; fibra bruta $7,7 \%$ e pectinas $1,6 \%$. Para o pólen armazenado na colônia o teor médio para umidade foi $23,8 \%$; matéria seca $76,2 \%$; proteínas $23,3 \%$; lipídios $5,4 \%$; amido $0,0 \%$; açúcares redutores $27,9 \%$; açúcares não 
redutores $2,5 \%$; cinzas $2,8 \%$; $\mathrm{pH} 4,1$; fibra bruta $10,6 \%$ e pectinas $0,5 \%$. Os autores concluíram que não ocorreram variações significativas no valor nutricional dos dois tipos de pólens avaliados, levando-se em consideração o número de crias operculadas em colônias que foram alimentadas com um ou outro tipo de pólen, apesar de ocorrerem alterações nos teores dos componentes físico-químicos avaliados após o acondicionamento do pólen nos favos da colônia.

Herbert Jr. \& Miller-Ihli (1987) estudaram a variação sazonal da composição química de sete minerais presentes nos pólens das plantas utilizadas por $A$. mellifera nos EUA e obtiveram os seguintes resultados: $\mathrm{K}$ de $4.711 \mu \mathrm{g} / \mathrm{g}$ a $10.448 \mu \mathrm{g} / \mathrm{g}$; Ca de 643 $\mu \mathrm{g} / \mathrm{g}$ a $2.522 \mu \mathrm{g} / \mathrm{g} ; \mathrm{Mg}$ de $604 \mu \mathrm{g} / \mathrm{g}$ a $1.580 \mu \mathrm{g} / \mathrm{g} ;$ Fe de $41 \mu \mathrm{g} / \mathrm{g}$ a $462 \mu \mathrm{g} / \mathrm{g}$; Mn de 17 $\mu \mathrm{g} / \mathrm{g}$ a $300 \mu \mathrm{g} / \mathrm{g}$; Zn de $40 \mu \mathrm{g} / \mathrm{g}$ a $114 \mu \mathrm{g} / \mathrm{g}$ e Cu de $4,7 \mu \mathrm{g} / \mathrm{g}$ a $29 \mu \mathrm{g} / \mathrm{g}$. Atribuíram as grandes variações nos teores dos minerais, provavelmente às fontes florais e às condições do solo, sob as quais os pólens tinham se desenvolvido.

Todd \& Bretherick (1942) determinaram a composição química de 32 espécies de plantas utilizadas por $A$. mellifera para a coleta de pólen nos EUA e observaram as seguintes variações: proteínas de $7,02 \%$ a $29,87 \%$ (com média de $21,60 \%$ ); lipídios de 0,94\% a 14,44\% (com média de 4,96\%); açúcares redutores de $18,82 \%$ a $41,21 \%$ (com média de $25,71 \%$ ); açúcares não redutores média de $2,71 \%$; umidade de $7,01 \%$ a $16,23 \%$ (com média de $11,16 \%$ ) e cinzas de $0,91 \%$ a $6,36 \%$ (com média de $2,70 \%$ ).

Vivino \& Palmer (1944) analisaram a composição química de 4 grupos de espécies de plantas utilizadas por $A$. mellifera para a coleta de pólen nos EUA e encontraram as seguintes médias: umidade $23,89 \%$; matéria seca $76,11 \%$; proteínas $20,15 \%$; lipídios $3,34 \%$ e cinzas $2,66 \%$.

Sampaio (1991) determinou a composição química do pólen coletado por $A$. mellifera no Brasil (Paraná), obtendo as seguintes variações: umidade de $2,61 \%$ a $11,06 \%$; proteínas de $13,84 \%$ a $27,84 \%$; lipídios de $2,17 \%$ a $5,63 \%$; cinzas de $1,58 \%$ a $3,61 \%$; açúcares redutores de $19,40 \%$ a $28,25 \%$; açúcares não redutores de $1,07 \%$ a $5,55 \%$; fibra bruta de $1,58 \%$ a $3,61 \%$ e pH de 4,60 a 5,90 . 
Singh et al. (1999) analisaram o teor de lipídios de espécies de plantas utilizadas por A. mellifera para a coleta de pólen na Índia e obtiveram as seguintes médias: 20,3\% para Brassica campestris var. Toria, 19,4\% para Cosmos bipinnatus, $17,8 \%$ para Raphanus sativum, 11,9\% para Helianthus annus e 11,6\% para Petunia hybrida.

Nielsen et al. (1955) estudaram o teor de proteínas de espécies de plantas utilizadas por $A$. mellifera para a coleta de pólen na Suécia. Obtiveram as seguintes médias: Zea mays: 26,0\%, Alnus glutinosa: 25,6\%, Alnus incana: 26,2\% e Pinus montana: $13,8 \%$.

Funari et al. (1998a), em determinação bromatológica e mineral do pólen coletado por $A$. mellifera $\mathrm{L}$. no Brasil (Botucatu), no período de agosto a novembro de 1996. Encontraram os seguintes valores: $75,9 \%$ de matéria seca, $26,2 \%$ de proteína bruta, $5,1 \%$ de lipidios, $1,1 \%$ de fibra bruta e $2,6 \%$ de minerais com os seguintes valores: $0,4 \%$ de $\mathrm{P} ; 0,67 \%$ de $\mathrm{K} ; 0,26 \%$ de $\mathrm{Ca} ; 0,08 \%$ de $\mathrm{Mg} ; 0,21 \%$ de $\mathrm{S} ; 114 \mathrm{ppm}$ de Fe; 88 ppm de $\mathrm{Zn} ; 15$ ppm de $\mathrm{Cu} ; 32$ ppm de $\mathrm{Mn}$ e 10 ppm de B.

\subsection{Necessidades de pólen por $A$. mellifera}

A importância do pólen para a colméia é inquestionável, pois dele dependem as abelhas para o seu suprimento de proteínas, sais minerais e produtos biológicos especiais, utilizados na sua alimentação. Por essa razão a produção de mel, cera e geléia real de um apiário está diretamente relacionada com a quantidade de pólen necessário para alimentação das colméias.

Haydak (1934) concluiu que as abelhas na ausência de pólen, recorrem a sua própria fonte de reserva, metabolizando tecidos de seus corpos para prolongar sua existência. Relatou também que logo ao receberem material nutritivo, no caso pólen, rapidamente assimilam os principais nutrientes que haviam perdido, reintegrando-se à normalidade.

Segundo Haydak (1970) as abelhas necessitam de 10 aminoácidos essenciais: arginina, histidina, lisina, triptofano, fenilalanina, metionina, treonina, leucina, 
isoleucina e valina, os quais são todos obtidos do pólen. Uma dieta deficiente em qualquer um desses animoácidos pode gerar sintomas específicos de deficiência, uma vez que as abelhas não poderão sintetizar as proteínas que os contenham.

Experimentos de alimentação demonstram uma necessidade média de $145 \mathrm{mg}$ de pólen para o desenvolvimento de uma abelha operária. Assim, uma colônia de 10.000 abelhas pode desenvolver-se normalmente com $1,5 \mathrm{~kg}$ de pólen. $\mathrm{O}$ valor nutritivo do pólen armazenado artificialmente depende das condições de secagem, temperatura e duração do tempo de armazenamento e da planta de origem do pólen. Todos estes fatores indicam que a composição química é a chave que determina a utilidade do pólen na nutrição da abelha (Stanley \& Linskens, 1974).

O uso do pólen é vital para a sobrevivência da colméia, já que as abelhas requerem entre 120 e $145 \mathrm{mg}$ diárias de pólen (Haydak, 1970). Segundo Root (1965) as necessidades de uma colméia normal são de $27 \mathrm{~kg}$ por ano; enquanto para Stanley \& Linskens (1974) o consumo anual médio é de 36 a $38 \mathrm{~kg}$ de pólen, podendo chegar a 55 $\mathrm{kg}$. Dávila et al. (1976) estimaram que de uma colméia bem povoada pode-se obter em torno de $50 \mathrm{~kg}$ de pólen por ano. Crailsheim et al. (1992) estudaram a utilização de pólen por operárias de $A$. mellifera carnica e estimaram que o consumo anual de pólen de um núcleo pode variar de 13,4 a $17,8 \mathrm{~kg}$.

Dietz (1979) observou que uma redução artificial na provisão de pólen de uma colméia de abelhas européias com resultante deficiência de proteína, terá como conseqüência um aumento na atividade de coleta de pólen.

Durante o período de escassez de alimento, a colméia naturalmente sofre uma diminuição populacional temporária, pois logo aumentará o número de abelhas jovens, de forma que haverá mais abelhas disponíveis para a coleta do alimento que começa a surgir no campo. Como resposta às mudanças na quantidade de alimento coletado, as abelhas regulam suas crias, mudando também a quantidade de pólen coletado (Dietz, 1975; Haydak, 1970; House, 1961). 


\subsection{Coletores de pólen}

Segundo Waller et al. (1981), o uso de coletores de pólen influenciam no desenvolvimento da cria e na população da colméia. No entanto, McLellan (1974) afirmou o contrário em relação à produção de cria e à quantidade de mel armazenado pois observou que o desenvolvimento da colméia, está diretamente ligado a escolha do coletor de pólen. Nelson et al. (1987) observaram uma pequena redução nas áreas ocupadas com crias operculadas nas colméias com coletores permanentemente instalados. Para Duff \& Furgala (1986a) a retirada de pólen da colméia via coletores de pólen resulta em um significante decréscimo na área de cria.

Funari et al. (1998b) verificaram que o uso de coletores de pólen não influenciou na composição bromatológica das pupas de corpo branco e olhos ligeiramente pigmentados. A composição média encontrada foi de $18,87 \%$ de matéria seca, 48,07\% de proteína bruta, $18,52 \%$ de lipídios e 3,72\% de minerais. Já Van Ass et al. (2000) concluíram que a presença, ou não, do coletor de pólen não influenciou o conteúdo de minerais presentes nas pupas com idade de "olhos cor de rosa", mas em relação aos teores de minerais nas pupas, verificaram efeito de época para os seguintes minerais: $\mathrm{P}$, $\mathrm{K}, \mathrm{Ca}, \mathrm{Zn}, \mathrm{Mg}, \mathrm{Cu}$ e $\mathrm{Mn}$.

Diversos autores notaram uma significativa redução na produção de mel nas colméias com coletores instalados: Nelson et al. (1987) de 20\%; Funari et al. (1998e) de 28\%; Lavie (1967) de 24,1\%; Duff \& Furgala (1986b) de 30\% no primeiro ano e 67\% no segundo; Aboulfaraj \& Furgala (1989) de $18 \%$ em 1987 e $38 \%$ no ano seguinte; Shawer (1987) de 28,8\%. No entanto, Bobrzecki \& Wilde $(1990,1991)$ e VasquezRomero et al. (1999) não verificaram nenhuma redução na produção de mel em função da instalação dos coletores de pólen. Já Villeneuve et al. (1988) obtiveram pequena redução $(4,6 \%)$ na produção de mel em colméias com coletores instalados mas não encontraram coeficiente de correlação positivo entre as produções de mel e de pólen das colméias com coletores intermitentemente instalados e as sem coletores. 
Shawer (1987) notou uma significativa redução na área de cria $(24,1,8 \%)$ e no pólen armazenado $(38,0 \%)$ em colméias com coletores instalados, enquanto que Waller et al. (1981) verificaram que coletores de pólen causam reduções nas áreas de cria e nas populações de abelhas e Vasquez-Romero et al. (1999) observaram que a área de cria foi reduzida após o segundo mês de instalação dos coletores.

Nelson et al. (1987) avaliaram colméias com coletores permanentemente instalados durante 3 anos (1983-85) no Canadá e obtiveram uma produção média anual de $9,4 \mathrm{~kg}$ de pólen. Funari et al. (1998c, e) verificaram uma produção média de $1,47 \mathrm{~kg}$ de pólen, com coletas diárias de 26,25 g, no período de agosto a dezembro de $1996 \mathrm{e}$ esses valores retirados causaram uma redução de $9,7 \%$ na área total de operária e de 4,0\% na área total de zangão, quando comparadas ao tratamento sem coletor de pólen.

Iannuzzi (1992) relatou que, em 1982, nos Estados Unidos, quando se intensificou a comercialização de pólen, os apicultores tiveram alguns problemas de ordem técnica na escolha do coletor mais adequado, pois além de não existirem trabalhos de pesquisa na área que pudessem orientá-los, havia um grande número de modelos de coletores de pólen no mercado.

Cornejo (1994) recomendou que a escolha de um modelo adequado às condições climáticas do local onde se encontram as colméias é muito importante, mas deve ser considerado também o comportamento e as características da espécie de Apis que se está trabalhando, além de seguir as regras de manejo para uma bem sucedida produção de pólen. $\mathrm{O}$ apicultor deve optar por um coletor de pólen de qualidade, observando o tamanho dos orificios ou da malha, que devem ser adequados ao tamanho das abelhas de cada região, podendo variar de $4,45 \mathrm{~mm}$ até $5,0 \mathrm{~mm}$ de diâmetro.

Objetivando verificar a eficiência dos coletores de pólen, Prost (1981), usou a técnica de contar o número de abelhas que entram na colméia carregando pólen; quando este número chegar a 100, ou seja, 200 bolotas de pólen tenham chegado ao alvado, retiramos a gaveta coletora e contamos o número coletado. Se 20 bolotas tiverem caído na gaveta, a eficiência do coletor é de $20 / 200 \times 100=10 \%$. Esta operação deve ser repetida várias vezes para que se obtenha uma média da efíciência do coletor. 
Segundo Morse (1986), um coletor eficiente conseguirá coletar mais de 50\% do pólen que entra na colméia. Afirmou também que, o uso deste dispositivo representa um esforço maior para a colméia, por isso deve ser usado em colméias populosas, saudáveis e em períodos em que o pólen seja abundante.

No entanto, Levin \& Loper (1984) utilizando o mesmo tipo de coletor de pólen obtiveram $33 \%$ de eficiência em um local e $66 \%$ em outro. Observaram também que nas colméias com coletores de pólen instalados as porcentagens de abelhas coletoras de pólen foram maiores e a quantidade de pólen armazenado foi menor do que nas colméias sem coletores. Funari et al. (1998d) relataram que a eficiência do coletor utilizado em seu experimento foi de $68 \pm 23,7 \%$ enquanto que Vasquez-Romero et al. (1999) obtiveram $78,28 \%$ e $79,90 \%$ de eficiência, respectivamente, para os coletores Apisvega e Induapicol.

Akatsu \& Pegoraro (2000) avaliaram a influência da largura do tórax de operárias de $A$. mellifera africanizadas na eficiência da tela de coletor de pólen e concluíram que esta característica não influenciou a eficiência da tela dos coletores utilizados (4 $\mathrm{mm}$ de espessura e 4,5 $\mathrm{mm}$ de diâmetro de orificio).

O pólen pode também ser analisado através da carga das abelhas operárias ou através das próprias abelhas. $O$ segundo método envolve matar as operárias, ou atordoálas por um curto período de tempo mediante exposição a gás $\left(\mathrm{CO}_{2}\right.$, etc.). Suas cargas podem ser removidas com segurança enquanto a abelha está inconsciente ou dificultando a entrada das abelhas operárias na colméia (Moore et al., 1991).

Ochoa (1980) comprovou que as abelhas européias ao notarem que parte do pólen por elas coletado é retirado, diminuem instintivamente o tamanho das bolotas que transportam conseguindo dessa maneira vencer o anteparo dos coletores de pólen.

Prost (1981) deduziu que as colméias mais aptas para a produção de pólen, são também as melhores produtoras de mel e mais ricas em postura. Recomendou colocar os coletores em colméias fortes, mas não nas colméias muito populosas, em que a superficie de postura se encontre em regressão durante o tempo de permanência do coletor. 


\section{MATERIAL E MÉTODOS}

O presente trabalho foi desenvolvido no Laboratório de Insetos Úteis e no Apiário do Departamento de Entomologia, Fitopatologia e Zoologia Agrícola da Escola Superior de Agricultura "Luiz de Queiroz", Universidade de São Paulo, Piracicaba - São Paulo, no período de março de 1999 a setembro de 2000.

As colméias utilizadas nos experimentos foram selecionadas por possuírem características semelhantes, apresentando população elevada, grandes áreas ocupadas por posturas, crias, pólen e mel.

Os coletores de pólen utilizados foram os de alvado (frontais) constituído por uma bandeja coletora e uma tela perfurada feita em acrílico com $3 \mathrm{~mm}$ de espessura, a qual foi perfurada com broca de alta rotação de $4,00 \mathrm{~mm}$ de diâmetro e as arestas foram retiradas para evitar danos às abelhas.

O resultado de cada amostra representa a média de 3 análises realizadas ( 3 repetições), exceto para as porcentagens de umidade, porcentagem de resíduo seco, porcentagem de açúcares redutores totais e granulometria que são de amostras únicas.

Para a análise estatística foram considerados todos os dados referentes aos diferentes dias de observação, adotando-se o programa SAS (Statistical Analysis System, 1997) e o teste de Tukey em nível de 5\% para a comparação de médias das áreas com crias e alimentos em colméias com coletores de pólen intermitentemente instalados e para os resultados das análises físico-químicas; já para as médias das áreas com crias e alimentos em colméias com coletores permanentemente instalados foi utilizado um modelo de regressão linear, por ser o qual melhor se ajustou aos resultados obtidos. 


\section{1 Áreas com posturas, crias, pólen e mel em colméias}

A determinação foi realizada segundo a técnica de Al-Tikrity \& Hillmann (1971), consistindo na quantificação, a cada 15 dias, das áreas (expressas em $\mathrm{cm}^{2}$ ) dos quadros ocupadas por posturas, crias, pólen e mel em cada colméia.

Foram realizados dois experimentos:

O primeiro durante o período de 17/04/99 a 18/03/00, avaliando-se em 5 colméias (exceto a partir de 11/12/99, quando houve o abandono de 1 colméia pelas abelhas devido a problemas ocasionados pela estiagem prolongada que causou atraso no florescimento das plantas e conseqüentemente redução nas fontes alimentares por elas visitadas). Os valores obtidos foram correlacionados com os parâmetros físico-químicos encontrados nas análises do pólen.

No segundo experimento as determinações foram realizadas de 17/06/00 a 09/09/00, utilizando-se 5 colméias, as quais foram mantidas com os coletores de pólen permanentemente instalados.

\subsection{Eficiência do coletor de pólen de alvado}

As observações foram realizadas durante 30 dias consecutivos, no período de 19/06/2000 a 20/07/2000, em 5 colméias com coletores permanentemente instalados.

\subsection{Atividade de coleta de pólen}

A atividade de coleta de pólen por A. mellifera foi realizada segundo a metodologia proposta por Westcott \& Winston (1999). Foram feitas observações às 8:00h, 11:00h e 16:00h, no período de 19/06/2000 a 20/07/2000, em 5 colméias com coletores permanentemente instalados e em outras 5 colméias sem esse equipamento. 


\subsection{Influência do estado da colméia na atividade de coleta de pólen}

A determinação da influência do estado da colméia (com ou sem rainha) na atividade de coleta de pólen por $A$. mellifera, foi realizada no período, de 19/06/2000 a 19/07/2000 em 5 colméias com rainhas e em 5 colméias sem rainhas, com coletores permanentemente instalados no período de 01/07/2000 a 15/07/2000.

\subsection{Média semanal de pólen coletado por $\boldsymbol{A}$. mellifera}

A coleta de pólen foi realizada no período de 3 meses consecutivos (19/06/2000 a 08/09/2000) em 5 colméias com rainhas e com coletores de pólen permanentemente instalados.

\subsection{Pólen coletado para as análises físico-químicas}

A coleta de pólen para as análises físico-químicas foi realizada através de coletores de alvado em 5 colméias, durante o período de 24/03/99 a 10/12/00. A partir de $11 / 12 / 99$ até $03 / 03 / 00$ foram utilizadas 4 colméias devido ao abandono de um enxame.

O material coletado sofria limpeza (retirada de impurezas) e era seco em estufa, de acordo com a metodologia proposta por Funari et al. (1998d). Após a secagem foi acondicionado em recipientes plásticos de $200 \mathrm{ml}$ hermeticamente fechados (utilizados para a comercialização de suco de laranja), e armazenados sob refrigeração $\left( \pm 7^{\circ} \mathrm{C}\right)$ até a sua utilização nas análises físico-químicas. 


\subsection{Análises físico-químicas do pólen}

Para a realização das análises físico-químicas do pólen, foram adotadas as seguintes metodologias:

Normas Analíticas do Instituto Adolfo Lutz, segundo Pregnolato \& Pregnolato (1985), para as determinações de: porcentagem de nitrogênio protéico, porcentagem de cinzas, porcentagem de umidade, porcentagem de resíduo seco, porcentagem de lipídios, determinação eletrométrica do $\mathrm{pH}$ e acidez titulável.

Para a determinação das porcentagens de açúcares redutores totais, foi adotada a metodologia proposta por Mokrasch (1954).

Para a determinação da granulometria do pólen coletado por A. mellifera, adaptou-se a metodologia proposta por Camargo et al. (1986), como segue: o pólen foi retirado diariamente dos coletores, no período, de 19/06/2000 a 19/07/2000, utilizandose um conjunto composto por 5 malhas, com as seguintes aberturas: $2,00 \mathrm{~mm} / \mu \mathrm{m}$ $(\mathrm{ABNT} / \mathrm{ASTM}=10), 1,00 \mathrm{~mm} / \mu \mathrm{m}(\mathrm{ABNT} / \mathrm{ASTM}=18), 0,50 \mathrm{~mm} / \mu \mathrm{m}(\mathrm{ABNT} / \mathrm{ASTM}$ $=35), 0,300 \mathrm{~mm} / \mu \mathrm{m}(\mathrm{ABNT} / \mathrm{ASTM}=50)$ e $0,106 \mathrm{~mm} / \mu \mathrm{m}(\mathrm{ABNT} / \mathrm{ASTM}=140) . \mathrm{O}$ material coletado após ser seco em estufa, de acordo com a metodologia proposta por Funari et al. (1998d), era separado de acordo com a sua granulometria em 5 categorias através do uso das peneiras. A seguir o material era pesado e os seus valores anotados. 


\section{RESULTADOS E DISCUSSÃo}

As coletas foram feitas de forma a obter-se quantidades de pólen suficientes para a realização das análises físico-químicas, buscando-se uma boa distribuição ao longo de todo $o$ ano e tomando-se o cuidado para que não causasse um esgotamento das reservas alimentares das colméias, tendo-se em vista que também eram utilizadas simultaneamente para o acompanhamento dos parâmetros biológicos (medições das áreas com posturas e crias) e das reservas alimentares (pólen e mel).

\subsection{Dados biológicos}

\subsection{1 Áreas com ovos de $A$. mellifera}

As áreas $\left(\mathrm{cm}^{2}\right)$ com ovos de A. mellifera apresentaram variações estatisticamente significativas com média de $437,36 \mathrm{~cm}^{2}$ (máx. de 714,33 e mín. de 187,25) para os meses de outubro de 1999 e fevereiro de 2000, respectivamente (Tabela 01). 
Tabela 01. Áreas $\left(\mathrm{cm}^{2}\right)$ com ovos em colméias de A. mellifera com coletores de pólen intermitentemente instalados; de 17/04/99 a 18/03/00, em Piracicaba, SP. *

\begin{tabular}{|c|c|c|c|c|c|c|c|c|}
\hline \multirow[b]{2}{*}{ Anos } & \multirow[b]{2}{*}{ Meses } & \multicolumn{5}{|c|}{ Colméias } & \multirow{2}{*}{\multicolumn{2}{|c|}{ Médias }} \\
\hline & & 1 & 2 & 3 & 4 & 5 & & \\
\hline \multirow{9}{*}{1999} & Abril & 468,00 & 404,00 & 752,00 & 440,00 & 612,00 & 535,20 & $a b$ \\
\hline & Maio & 465,33 & 318,67 & 505,33 & 526,67 & 472,33 & 457,67 & $a b c$ \\
\hline & Junho & 662,00 & 482,00 & 436,00 & 546,00 & 540,00 & 533,20 & $a b$ \\
\hline & Julho & 243,50 & 479,50 & 247,00 & 179,50 & 387,50 & 307,40 & bc \\
\hline & Agosto & 250,00 & 176,00 & 614,00 & 442,00 & 610,00 & 418,40 & $a b c$ \\
\hline & Setembro & 521,50 & 238,50 & 406,50 & 1067,00 & 557,00 & 558,10 & $a b$ \\
\hline & Outubro & 565,33 & 338,00 & 771,00 & 1070,67 & 826,67 & 714,33 & $\mathbf{a}$ \\
\hline & Novembro & 371,50 & 551,50 & 376,00 & 757,50 & 874,00 & 586,10 & $a b$ \\
\hline & Dezembro & * & 559,50 & 369,50 & 282,50 & 515,00 & 431,63 & $a b c$ \\
\hline \multirow{3}{*}{2000} & Janeiro & $*$ & 392,50 & 275,50 & 206,00 & 313,00 & 296,75 & bc \\
\hline & Fevereiro & $*$ & 194,00 & 159,00 & 156,50 & 239,50 & 187,25 & c \\
\hline & Março & $*$ & 184,50 & 149,50 & 231,00 & 323,00 & 222,00 & c \\
\hline
\end{tabular}

Médias seguidas por letras distintas diferem estatisticamente entre si, em nível de $5 \%$ de significância, pelo teste de Tukey. *A partir de 11/12/99 foram utilizadas 4 colméias devido ao abandono de um enxame. Coeficiente de variação igual a $18,19 \%$.

Os resultados obtidos demonstram a grande variabilidade nas médias das áreas $\left(\mathrm{cm}^{2}\right)$ com ovos em colméias de A. mellifera com coletores de pólen intermitentemente instalados, durante os meses do ano, sendo que o maior valor ocorreu no mês de outubro de 1999 e os menores em fevereiro e março de 2000.

Segundo Doull (1968) essas grandes variações seriam devidas aos períodos de carência de pólen, pois em colméias que receberam suplementação protéica todos os ovos colocados pela rainha transfomaram-se em larvas, enquanto que nas colônias que não receberam suplementação apenas $20 \%$ dos ovos eclodiram. Essa diferença entre os dois grupos foi mantida até que foram transferidos para uma região rica em pólen e todos os ovos se transformaram em larvas. No entanto, a coleta de pólen pode ser limitada quando há pólen ou suplemento protéico na colônia (Barker, 1971). Cale Jr. (1968) encontrou uma correlação positiva entre a postura da rainha e a coleta de pólen, supondo que a coleta é conseqüência direta da necessidade protéica das abelhas.

Hellmich II \& Rothenbuhler (1986) afirmaram que a presença de ovos estimulam a coleta de pólen. 


\subsection{2 Áreas com crias desoperculadas que darão origem as operárias de $\boldsymbol{A}$. mellifera}

As áreas $\left(\mathrm{cm}^{2}\right)$ com crias desoperculadas que darão origem as operárias de $A$. mellifera apresentaram variações estatisticamente significativas, com média de 820,66 $\mathrm{cm}^{2}$ (máx. de 1645,60 e mín. de 246,25) para os meses de abril de 1999 e fevereiro de 2000 , respectivamente (Tabela 02).

Tabela 02. Áreas $\left(\mathrm{cm}^{2}\right) \mathrm{com}$ crias desoperculadas que darão origem as operárias em colméias de $A$. mellifera com coletores de pólen intermitentemente instalados, de 17/04/99 a 18/03/00, em Piracicaba, SP. *

\begin{tabular}{|c|c|c|c|c|c|c|c|c|}
\hline \multirow[b]{2}{*}{ Anos } & \multirow[b]{2}{*}{ Meses } & \multicolumn{5}{|c|}{ Colméias } & \multirow[b]{2}{*}{ Médias } & \\
\hline & & 1 & 2 & 3 & 4 & 5 & & \\
\hline \multirow{9}{*}{1999} & Abril & 852,00 & 928,00 & 2640,00 & 836,00 & 2972,00 & 1645,60 & $\bar{a}$ \\
\hline & Maio & 1130,67 & 764,33 & 1226,67 & 1257,33 & 1706,67 & 1217,13 & $a b$ \\
\hline & Junho & 868,00 & 616,00 & 830,00 & 282,00 & 1300,00 & 779,20 & abcde \\
\hline & Julho & 641,50 & 1179,00 & 914,50 & 311,50 & 1678,50 & 945,00 & $a b c$ \\
\hline & Agosto & 426,00 & 846,00 & 1082,00 & 870,00 & 1758,00 & 996,40 & $a b c$ \\
\hline & Setembro & 961,50 & 987,00 & 621,50 & 722,00 & 1520,00 & 962,40 & $a b c$ \\
\hline & Outubro & 887,33 & 693,33 & 941,33 & 735,67 & 1021,00 & 855,73 & $a b c d$ \\
\hline & Novembro & 880,50 & 779,50 & 682,50 & 875,00 & 1269,50 & 897,40 & $a b c d$ \\
\hline & Dezembro & $*$ & 582,00 & 689,50 & 584,50 & 714,00 & 642,50 & bcde \\
\hline \multirow{3}{*}{2000} & Janeiro & $*$ & 343,00 & 408,50 & 312,50 & 426,00 & 372,50 & cde \\
\hline & Fevereiro & $*$ & 259,00 & 233,50 & 205,00 & 287,50 & 246,25 & $e$ \\
\hline & Março & $*$ & 342,00 & 240,00 & 192,00 & 377,00 & 287,75 & de \\
\hline
\end{tabular}

Médias seguidas por letras distintas diferem estatisticamente entre si, em nível de $5 \%$ de significância, pelo teste de Tukey. "A partir de 11/12/99 foram utilizadas 4 colméias devido ao abandono de um enxame. Coeficiente de variação igual a $21,99 \%$.

Verificou-se através dos resultados obtidos a grande variabilidade nas médias das áreas $\left(\mathrm{cm}^{2}\right)$ crias desoperculadas que darão origem as operárias em colméias de $A$. mellifera com coletores de pólen intermitentemente instalados, durante os meses do ano, sendo que o maior valor ocorreu no mês de abril de 1999 e o menor em fevereiro de 2000.

Eckert et al. (1994) avaliaram o comportamento de coleta de pólen em colônias com grandes áreas de cria $\left(9600 \pm 408 \mathrm{~cm}^{2}\right)$ e com pequenas áreas de cria $(1600 \pm 80$ $\mathrm{cm}^{2}$ ). Verificaram que as campeiras de colônias com grandes áreas de cria coletavam 
cargas maiores, no entanto, quanto ao número de abelhas coletoras de pólen não foram verificadas diferenças estatisticamente significativas entre os dois tratamentos.

Barker (1971) encontrou correlação positiva entre a coleta de pólen e as colméias nas quais as áreas de crias estão diminuindo.

Free (1967) afirmou que as crias desoperculadas são um fator muito eficiente para estimular a coleta de pólen pela abelha melífera.

\subsection{3 Áreas com crias operculadas que darão origem as operárias de $A$. mellifera}

As áreas $\left(\mathrm{cm}^{2}\right)$ com crias operculadas que darão origem as operárias de $A$. mellifera apresentaram variações estatisticamente significativas, com média de 2015,96 $\mathrm{cm}^{2}$ (máx. de 2694,10 e mín. de 1320,00) para os meses de novembro de 1999 e fevereiro de 2000, respectivamente (Tabela 03).

Tabela 03. Áreas $\left(\mathrm{cm}^{2}\right)$ com crias operculadas que darão origem as operárias em colméias de $A$. mellifera com coletores de pólen intermitentemente instalados, de 17/04/99 a 18/03/00, em Piracicaba, SP. *

\begin{tabular}{|c|c|c|c|c|c|c|c|c|}
\hline \multirow[b]{2}{*}{ Anos } & \multicolumn{6}{|c|}{ Colméias } & \multirow{2}{*}{\multicolumn{2}{|c|}{ Médias }} \\
\hline & Meses & 1 & 2 & 3 & 4 & 5 & & \\
\hline \multirow{9}{*}{1999} & Abril & 1980,00 & 2480,00 & 3240,00 & 3280,00 & 2320,00 & 2660,00 & $a b$ \\
\hline & Maio & 1844,67 & 2341,33 & 2837,33 & 2129,33 & 2138,67 & 2258,27 & $a b c$ \\
\hline & Junho & 2330,00 & 2230,00 & 1556,00 & 1394,00 & 3044,00 & 2110,80 & $a b c$ \\
\hline & Julho & 1997,50 & 2132,50 & 2031,50 & 1191,00 & 3191,50 & 2108,80 & $a b c$ \\
\hline & Agosto & 1156,00 & 1760,00 & 1938,00 & 1902,00 & 3548,00 & 2060,80 & $a b c$ \\
\hline & Setembro & 1944,50 & 1521,50 & 1405,50 & 2892,50 & 2430,00 & 2038,80 & $a b c$ \\
\hline & Outubro & 1923,00 & 1276,33 & 1873,67 & 2603,33 & 1924,00 & 1920,07 & $a b c$ \\
\hline & Novembro & 1645,50 & 2767,50 & 2754,50 & 3025,50 & 3277,50 & 2694,10 & a \\
\hline & Dezembro & * & 2140,00 & 2058,00 & 1805,00 & 2110,50 & 2028,38 & $a b c$ \\
\hline \multirow{3}{*}{2000} & Janeiro & * & 1574,50 & 1565,50 & 1313,50 & 1658,00 & 1527,88 & $b c$ \\
\hline & Fevereiro & * & 1578,00 & 1372,00 & 1006,00 & 1324,00 & 1320,00 & c \\
\hline & Março & * & 1559,00 & 1397,50 & 1124,00 & 1774,00 & 1463,63 & c \\
\hline
\end{tabular}

Médias seguidas por letras distintas diferem estatisticamente entre si, em nível de $5 \%$ de significância, pelo teste de Tukey. *A partir de 11/12/99 foram utilizadas 4 colméias devido ao abandono de um enxame. Coeficiente de variação igual a $12,78 \%$.

Os resultados obtidos confirmam a afirmação de Eckert et al. (1994) de que nas colméias de $A$. mellifera ocorrem grandes variações nas médias das áreas com crias durante o ano, sendo que os maiores valores de áreas com crias operculadas que darão 
origem as operárias ocorreram no mês de novembro e os menores valores em fevereiro e março de 2000.

Todd \& Reed (1970) estabeleceram a relação direta entre a quantidade de pólen coletado por uma colônia e as suas quantidades de crias (desoperculadas e operculadas).

Segundo Hellmich II \& Rothenbuhler (1986) a presença de larvas estimulam a coleta de pólen e o seu uso, neste caso particularmente as maiores.

\subsection{4 Áreas com óvulos de $A$. mellifera}

As áreas $\left(\mathrm{cm}^{2}\right)$ com óvulos de $A$. mellifera apresentaram variações estatisticamente significativas, com média de $4,56 \mathrm{~cm}^{2}$ (máx. de 20,38 e mín. de 0,00 ) para os mês de janeiro de 2000 e em vários meses de 1999, respectivamente (Tabela 04).

Tabela 04. Áreas $\left(\mathrm{cm}^{2}\right)$ com óvulos em colméias de $A$. mellifera com coletores de pólen intermitentemente instalados, de 17/04/99 a 18/03/00, em Piracicaba, SP. *

\begin{tabular}{|c|c|c|c|c|c|c|c|c|}
\hline \multirow[b]{2}{*}{ Anos } & \multirow[b]{2}{*}{ Meses } & \multicolumn{5}{|c|}{ Colméias } & \multirow{2}{*}{\multicolumn{2}{|c|}{ Médias }} \\
\hline & & 1 & 2 & 3 & 4 & 5 & & \\
\hline \multirow{9}{*}{1999} & Abril & 0,00 & 0,00 & 0,00 & 0,00 & 0,00 & 0,00 & $\mathrm{c}$ \\
\hline & Maio & 0,00 & 0,00 & 0,00 & 0,00 & 0,00 & 0,00 & c \\
\hline & Junho & 0,00 & 0,00 & 0,00 & 0,00 & 0,00 & 0,00 & $\mathrm{c}$ \\
\hline & Julho & 0,00 & 0,00 & 0,00 & 0,00 & 0,00 & 0,00 & $\mathrm{c}$ \\
\hline & Agosto & 0,00 & 0,00 & 0,00 & 0,00 & 0,00 & 0,00 & $\mathrm{c}$ \\
\hline & Setembro & 0,00 & 0,00 & 0,00 & 0,00 & 0,00 & 0,00 & c \\
\hline & Outubro & 0,00 & 0,00 & 0,00 & 0,00 & 0,00 & 0,00 & $\mathrm{c}$ \\
\hline & Novembro & 0,00 & 0,00 & 0,00 & 10,00 & 0,00 & 2,00 & c \\
\hline & Dezembro & * & 6,50 & 11,50 & 22,00 & 22,00 & 15,50 & $a b$ \\
\hline \multirow{3}{*}{2000} & Janeiro & * & 14,50 & 21,00 & 19,00 & 27,00 & 20,38 & $a$ \\
\hline & Fevereiro & $*$ & 10,00 & 9,00 & 4,50 & 11,00 & 8,63 & b \\
\hline & Março & * & 12,00 & 4,00 & 3,00 & 14,00 & 8,25 & b \\
\hline
\end{tabular}

Médias seguidas por letras distintas diferem estatisticamente entre si, em nivel de $5 \%$ de significância, pelo teste de Tukey. *A partir de 11/12/99 foram utilizadas 4 colméias devido ao abandono de um enxame: Coeficiente de variação igual a $30,47 \%$.

Os resultados obtidos deixam claro que existe uma grande sazonalidade nas médias das áreas $\left(\mathrm{cm}^{2}\right)$ com óvulos em colméias de $A$. mellifera durante os meses do ano, sendo que o maior valor ocorreu no mês de janeiro. 
Free \& Williams (1975) afirmaram que as colônias produzem zangões durante toda a estação reprodutiva, mas o pico ocorre no período entre a primavera e o início do verão, em regiões de clima temperado.

\subsection{5 Áreas com crias desoperculadas que darão origem a zangões de $A$. mellifera}

As áreas $\left(\mathrm{cm}^{2}\right)$ com crias desoperculadas que darão origem a zangões de $A$. mellifera apresentaram variações estatisticamente significativas, com média de 17,60 $\mathrm{cm}^{2}$ (máx. de 90,40 e mín. de 0,00) para os mês de abril de 1999 e em julho, agosto e novembro de 1999 (Tabela 05).

Tabela 05. Áreas $\left(\mathrm{cm}^{2}\right)$ com crias desoperculadas que darão origem a zangões em colméias de $A$. mellifera com coletores de pólen intermitentemente instalados, de 17/04/99 a 18/03/00, em Piracicaba, SP. *

\begin{tabular}{|c|c|c|c|c|c|c|c|}
\hline \multirow[b]{2}{*}{ Anos } & \multirow[b]{2}{*}{ Meses } & \multicolumn{5}{|c|}{ Colméias } & \multirow[b]{2}{*}{ Médias } \\
\hline & & 1 & 2 & 3 & 4 & 5 & \\
\hline \multirow{9}{*}{1999} & Abril & 0,00 & 0,00 & 240,00 & 0,00 & 212,00 & 90,40 a \\
\hline & Maio & 42,33 & 38,00 & 0,00 & 93,33 & 0,00 & $34,73 \mathrm{ab}$ \\
\hline & Junho & 0,00 & 2,00 & 0,00 & 0,00 & 0,00 & $0,40 \mathrm{ab}$ \\
\hline & Julho & 0,00 & 0,00 & 0,00 & 0,00 & 0,00 & $0,00 \quad t$ \\
\hline & Agosto & 0,00 & 0,00 & 0,00 & 0,00 & 0,00 & 0,00 \\
\hline & Setembro & 0,00 & 0,00 & 4,50 & 0,00 & 9,50 & $2,80 \mathrm{ab}$ \\
\hline & Outubro & 17,33 & 12,33 & 24,00 & 21,33 & 19,33 & $18,87 \mathrm{ab}$ \\
\hline & Novembro & 0,00 & 0,00 & 0,00 & 0,00 & 0,00 & $0,00 \quad \mathrm{t}$ \\
\hline & Dezembro & * & 18,00 & 6,50 & 38,00 & 34,00 & 24,13 ab \\
\hline \multirow{3}{*}{2000} & Janeiro & $*$ & 15,00 & 22,50 & 25,00 & 25,50 & $22,00 \mathrm{ab}$ \\
\hline & Fevereiro & * & 21,00 & 6,50 & 3,50 & 11,50 & $10,63 \mathrm{ab}$ \\
\hline & Março & $*$ & 10,00 & 3,00 & 2,00 & 14,00 & $7,25 \mathrm{ab}$ \\
\hline
\end{tabular}

Médias seguidas por letras distintas diferem estatisticamente entre si, em nível de $5 \%$ de significância, pelo teste de Tukey. *A partir de 11/12/99 foram utilizadas 4 colméias devido ao abandono de um enxame. Coeficiente de variação igual a $89,02 \%$.

Os dados permitem visualizar uma grande sazonalidade nas médias das áreas $\left(\mathrm{cm}^{2}\right)$ ocupadas com crias desoperculadas que darão origem a zangões em colméias de A. mellifera durante os meses do ano, sendo que os maiores valores ocorreram no mês de abril. 


\subsection{6 Áreas com crias operculadas que darão origem a zangões de $A$. mellifera}

As áreas $\left(\mathrm{cm}^{2}\right)$ com crias operculadas que darão origem a zangões de $A$. mellifera apresentaram variações estatisticamente significativas, com média de $22,06 \mathrm{~cm}^{2}$ (máx. de 103,07 e mín. de 1,60) para os meses de maio de 1999 e junho de 1999, respectivamente (Tabela 06 ).

Tabela 06. Áreas $\left(\mathrm{cm}^{2}\right)$ com crias operculadas que darão origem a zangões em colméias de $A$. mellifera com coletores de pólen intermitentemente instalados, de 17/04/99 a 18/03/00, em Piracicaba, SP. *

\begin{tabular}{|c|c|c|c|c|c|c|c|c|}
\hline \multirow[b]{2}{*}{ Anos } & \multirow[b]{2}{*}{ Meses } & \multicolumn{5}{|c|}{ Colméias } & \multirow{2}{*}{\multicolumn{2}{|c|}{ Médias }} \\
\hline & & 1 & 2 & 3 & 4 & 5 & & \\
\hline \multirow{9}{*}{1999} & Abril & 0,00 & 0,00 & 0,00 & 52,00 & 0,00 & 10,40 & b \\
\hline & Maio & 0,00 & 46,00 & 80,00 & 246,67 & 142,67 & 103,07 & $\mathbf{a}$ \\
\hline & Junho & 0,00 & 4,00 & 0,00 & 4,00 & 0,00 & 1,60 & b \\
\hline & Julho & 0,00 & 0,00 & 6,00 & 8,00 & 0,00 & 2,80 & $b$ \\
\hline & Agosto & 0,00 & 16,00 & 0,00 & 0,00 & 0,00 & 3,20 & b \\
\hline & Setembro & 8,50 & 3,50 & 5,50 & 0,00 & 11,50 & 5,80 & b \\
\hline & Outubro & 13,67 & 9,00 & 147,00 & 22,67 & 29,00 & 44,27 & $\mathbf{a b}$ \\
\hline & Novembro & 0,00 & 0,00 & 94,00 & 80,00 & 0,00 & 34,80 & $a b$ \\
\hline & Dezembro & $*$ & 6,50 & 9,00 & 24,50 & 27,00 & 16,75 & $a b$ \\
\hline \multirow{3}{*}{2000} & Janeiro & $*$ & 28,00 & 21,50 & 24,50 & 22,00 & 24,00 & $a b$ \\
\hline & Fevereiro & * & 13,00 & 8,50 & 10,50 & 15,50 & 11,88 & b \\
\hline & Março & $*$ & 8,50 & 5,00 & 3,00 & 8,00 & 6,13 & b \\
\hline
\end{tabular}

Médias seguidas por letras distintas diferem estatisticamente entre si, em nível de $5 \%$ de significância, pelo teste de Tukey. *A partir de 11/12/99 foram utilizadas 4 colméias devido ao abandono de um enxame. Coeficiente de variação igual a $74,50 \%$.

Os resultados obtidos demostram a grande sazonalidade (este pode ser visualizado no alto coeficiente de variação) nas médias das áreas $\left(\mathrm{cm}^{2}\right)$ com crias operculadas que darão origem a zangões em colméias de $A$. mellifera durante os meses do ano, sendo que o maior valor ocorrereu no mês de maio de 1999 .

Nas regiões temperadas o pico da emergência dos zangões ocorre justamente antes do período da enxameação, na época que as rainhas virgens estão disponíveis, sendo que a sua alta produção neste momento reflete um esforço reprodutivo para anteceder o inverno (Lee \& Winston, 1987). 


\subsection{7 Áreas com pólen em colméias de $A$. mellifera}

As áreas $\left(\mathrm{cm}^{2}\right)$ com pólen em colméias de $A$. mellifera apresentaram variações estatisticamente significativas, com média de $579,78 \mathrm{~cm}^{2}$ (máx, de 995,20 e mín. de 162,63) para os meses de agosto de 1999 e fevereiro de 2000, respectivamente (Tabela $07)$.

Tabela 07. Áreas $\left(\mathrm{cm}^{2}\right)$ com pólen em colméias de $A$. mellifera com coletores de pólen intermitentemente instalados, de 17/04/99 a 18/03/00, em Piracicaba, SP. *

\begin{tabular}{|c|c|c|c|c|c|c|c|c|}
\hline \multirow[b]{2}{*}{ Anos } & \multirow[b]{2}{*}{ Meses } & \multicolumn{5}{|c|}{ Colméias } & \multirow{2}{*}{\multicolumn{2}{|c|}{ Médias }} \\
\hline & & 1 & 2 & 3 & 4 & 5 & & \\
\hline \multirow{9}{*}{1999} & Abril & 840,00 & 1004,00 & 1464,00 & 512,00 & 860,00 & 936,00 & $a$ \\
\hline & Maio & 493,33 & 654,33 & 704,00 & 578,67 & 562,33 & 598,53 & $a b c$ \\
\hline & Junho & 370,00 & 1251,00 & 774,00 & 284,00 & 1400,00 & 815,80 & $a b$ \\
\hline & Julho & 305,00 & 1493,00 & 135,00 & 520,50 & 1300,00 & 750,70 & $a b c$ \\
\hline & Ágosto & 864,00 & 1186,00 & 514,00 & 806,00 & 1606,00 & 995,20 & $\mathbf{a}$ \\
\hline & Setembro & 1601,00 & 704,00 & 402,50 & 444,50 & 882,00 & 806,80 & ab \\
\hline & Outubro & 883,33 & 255,67 & 629,67 & 372,00 & 985,33 & 625,20 & $a b c$ \\
\hline & Novembro & 625,00 & 291,00 & 211,50 & 267,00 & 870,50 & 453,00 & $a b c$ \\
\hline & Dezembro & $*$ & 339,50 & 247,00 & 231,00 & 478,00 & 323,88 & $a b c$ \\
\hline \multirow{3}{*}{2000} & Janeiro & $*$ & 272,50 & 260,00 & 172,00 & 297,50 & 250,50 & $b c$ \\
\hline & Fevereiro & $*$ & 169,50 & 175,00 & 100,00 & 206,00 & 162,63 & c \\
\hline & Março & $*$ & 206,00 & 178,00 & 231,50 & 341,00 & 239,13 & $b c$ \\
\hline
\end{tabular}

Médias seguidas por letras distintas diferem estatisticamente entre si, em nivel de $5 \%$ de significância, pelo teste de Tukey. *A partir de 11/12/99 foram utilizadas 4 colméias devido ao abandono de um enxame. Coeficiente de variação igual a $27,45 \%$.

Os resultados obtidos apresentaram grande variabilidade nas médias das áreas $\left(\mathrm{cm}^{2}\right)$ com pólen em colméias de $A$. mellifera durante os meses do ano, sendo que os maiores valores ocorreram nos meses de agosto e abril de 1999.

A coleta máxima de pólen depende da presença de cria jovem na colméia (Barker, 1971; Free, 1967). Dreller et al. (1999) também citaram a influência da quantidade de pólen armazenado e a presença de espaços vazios nos alvéolos como fatores importantes na coleta de pólen.

Jeffree \& Allen (1957) estudaram o ciclo anual de armazenamento do pólen pelas abelhas na Escócia. Observaram os maiores valores nos meses de junho, julho e agosto, 
sendo que a partir de setembro a quantidade armazenada vai decrescendo até abril quando com o reinício das coletas os valores aumentam novamente.

Haydak (1967) comparou o desenvolvimento de colônias de abelhas privadas de pólen, alimentadas só com xarope de açúcar e colônias alimentadas normalmente. $\mathrm{O}$ grupo que não recebeu pólen apresentou mortalidade maior $(59,9 \%)$ do que as do grupo controle $(12,7 \%)$ e no final do período apresentaram pouco vigor, dificuldade para voar e pouca atenção com a rainha.

MacKensen \& Nye (1966) demonstraram, através da seleção de linhagens para alta ou baixa coleta de pólen de alfafa, que o comportamento forrageador da abelha melífera é de natureza herdável.

\subsection{8 Áreas com mel em colméias de $A$. mellifera}

As áreas $\left(\mathrm{cm}^{2}\right)$ com mel de $A$. mellifera apresentaram variações estatisticamente significativas, com média de $1325,31 \mathrm{~cm}^{2}$ (máx. de 2799,20 e mín. de 552,25) para os meses de maio de 1999 e fevereiro de 2000, respectivamente (Tabela 08).

Tabela 08. Áreas $\left(\mathrm{cm}^{2}\right)$ com mel em colméias de A. mellifera com coletores de pólen intermitentemente instalados, de 17/04/99 a 18/03/00, em Piracicaba, SP. *

\begin{tabular}{|c|c|c|c|c|c|c|c|c|}
\hline \multirow[b]{2}{*}{ Anos } & \multirow[b]{2}{*}{ Meses } & \multicolumn{5}{|c|}{ Colméias } & \multirow{2}{*}{\multicolumn{2}{|c|}{ Médias }} \\
\hline & & 1 & 2 & 3 & 4 & 5 & & \\
\hline \multirow{9}{*}{1999} & Abril & 2172,00 & 2460,00 & 992,00 & 1460,00 & 1684,00 & 1753,60 & $a b$ \\
\hline & Maio & 3385,33 & 2294,33 & 2386,67 & 3347,00 & 2582,67 & 2799,20 & $\mathbf{a}$ \\
\hline & Junho & 1178,00 & 816,00 & 214,00 & 1356,00 & 1974,00 & 1107,60 & $a b$ \\
\hline & Julho & 369,50 & 618,50 & 232,50 & 1287,50 & 1765,50 & 854,70 & b \\
\hline & Agosto & 368,00 & 3550,00 & 586,00 & 2194,00 & 1804,00 & 1700,40 & $a b$ \\
\hline & Setembro & 313,50 & 2570,50 & 271,50 & 1650,50 & 1273,00 & 1215,80 & $a b$ \\
\hline & Outubro & 379,67 & 1782,00 & 1610,00 & 1832,33 & 1523,67 & 1425,53 & $a b$ \\
\hline & Novembro & 481,50 & 1386,50 & 2419,00 & 2440,00 & 1837,50 & 1712,90 & $a b$ \\
\hline & Dezembro & * & 614,00 & 1337,50 & 1449,50 & 1488,00 & 1222,25 & $a b$ \\
\hline \multirow{3}{*}{2000} & Janeiro & * & 403,00 & 952,50 & 859,50 & 1069,50 & 821,13 & b \\
\hline & Fevereiro & * & 381,50 & 504,00 & 512,50 & 811,00 & 552,25 & b \\
\hline & Março & * & 572,50 & 677,50 & 689,00 & 1014,50 & 738,38 & b \\
\hline
\end{tabular}

Médias seguidas por letras distintas diferem estatisticamente entre si, em nível de $5 \%$ de significância, pelo teste de Tukey. *A partir de 11/12/99 foram utilizadas 4 colméias devido ao abandono de um enxame. Coeficiente de variação igual a $28,01 \%$. 
Os resultados obtidos evidenciaram as grandes alterações nas médias das áreas $\left(\mathrm{cm}^{2}\right)$ com mel em colméias de A. mellifera durante os meses do ano, sendo que o maior valor ocorrereu no mês de maio de 1999 e os menores nos meses de julho de 1999 e em janeiro, março e fevereiro de 2000.

A quantidade de mel estocado na colméia é igualmente importante para o desenvolvimento das crias e para a coleta de pólen (Barker, 1971). Barker (1971) e Cale Jr. (1968) encontraram correlações positivas entre as quantidades de mel na colméia e a coleta de pólen, sendo que o primeiro autor não verificou correlação entre as quantidades de pólen ou alvéolos vazios na colméia com a coleta de pólen.

Harbo (1986) analisando vários tamanhos de populações de abelhas, obteve que as duas maiores (17.000 e 35.000 abelhas) poduziram mais mel por abelha e no inverno o consumo por abelha foi menor do que nas menores populações $(2.300,4.500$ e 9.000 abelhas), no entanto estas foram mais eficientes para a produção de cria por abelha. Harbo (1993) determinou que as abelhas consomem $121 \mathrm{~g}$ de mel para produzir 1.000 células de crias de estágios variados (ovos, larvas e pupas).

\subsection{Análises físico-químicas}

\subsubsection{Porcentagens (\%) de proteína em amostras do pólen coletado por $A$. mellifera}

As porcentagens (\%) de proteínas em amostras do pólen coletado por $A$. mellifera, apresentaram variações estatisticamente significativas, com média de $21,38 \%$ (máx. de 22,78 e mín. de 20,07) para os meses de julho de 1999 e abril de 1999, respectivamente (Tabela 09 ). 
Tabela 09. Porcentagens (\%) de proteínas em amostras do pólen coletado em colméias de $A$. mellifera com coletores de pólen intermitentemente instalados, em Piracicaba, SP. *

\begin{tabular}{|c|c|c|c|c|c|c|c|}
\hline \multirow[b]{2}{*}{ Anos } & \multirow[b]{2}{*}{ Meses } & \multicolumn{5}{|c|}{ Colméias } & \multirow[b]{2}{*}{ Médias } \\
\hline & & 1 & 2 & 3 & 4 & 5 & \\
\hline & Março & 19,26 & 19,84 & 20,23 & 20,62 & 21,32 & $20,25 \mathrm{~b}$ \\
\hline & Abril & 19,44 & 20,10 & 20,84 & 20,88 & 19,08 & $20,07 \mathrm{~b}$ \\
\hline & Maio & 20,64 & 21,66 & 21,81 & 21,52 & 21,79 & $21,48 \mathrm{ab}$ \\
\hline & Junho & 19,85 & 19,53 & 19,72 & 21,34 & 22,81 & $20,65 a b$ \\
\hline & Julho & 23,72 & 21,13 & 24,43 & 21,79 & 22,84 & 22,78 a \\
\hline \multirow{5}{*}{1999} & Agosto & 20,45 & 21,49 & 22,65 & 22,29 & 23,30 & $22,03 \mathrm{ab}$ \\
\hline & Setembro & 20,15 & 21,20 & 23,63 & 23,31 & 22,09 & $22,07 \mathrm{ab}$ \\
\hline & Outubro & 19,69 & 21,42 & 22,39 & 22,08 & 20,90 & $21,30 a b$ \\
\hline & Novembro & 21,84 & 22,10 & 21,28 & 20,76 & 21,71 & $21,54 \quad a b$ \\
\hline & Dezembro & * & 20,89 & 20,22 & 22,55 & 22,39 & $21,51 \mathrm{ab}$ \\
\hline & Janeiro & * & 19,82 & 22,26 & 24,30 & 22,55 & $22,23 \mathrm{ab}$ \\
\hline \multirow[t]{2}{*}{2000} & Fevereiro & $*$ & 21,05 & 20,97 & 22,58 & 22,77 & $21,84 a b$ \\
\hline & Março & * & 20,59 & 20,24 & 19,84 & 20,27 & $20,23 \quad b$ \\
\hline
\end{tabular}

Médias seguidas por letras distintas diferem estatisticamente entre si, em nível de $5 \%$ de significância, pelo teste de Tukey. *A partir de 11/12/99 foram utilizadas 4 colméias devido ao abandono de um enxame. Coeficiente de variação igual a $4,90 \%$.

Os resultados obtidos confirmam a variabilidade nas médias das porcentagens (\%) de proteínas durante os meses do ano. Autores encontraram pequenas variações nos teores observados: Vivino \& Palmer (1944) 20,15\%; Barreto et al. (2000) 20,33\% e $20,03 \%$, respectivamente para os meses de maio e junho; Costa et al. (2000) 30,45 \pm 1,02\%; Funari et al. (1998a) 26,2\%; Avila (1980) 35\%. No entanto outros verificaram grande variabilidade tais como: Almeida-Muradian \& Presoto (2000) 21,58 $\pm 6,26 \%$; Day et al. (1990) de 2,9\% a 23,5\%; Youssef et al. (1978) de 23,3\% a 37,7\%; Todd \& Bretherick (1942) de 7,02\% a 29,87\% (média de 21,60\%); Sampaio (1991) de 13,84\% a 27,84\%; Ochoa (1980) de 20 a 40\%, Nielsen et al. (1955) de 13,8\% a 26,0\%. Já Herbert Jr. \& Shimanuki (1978) obtiveram os valores de $24,1 \%$ e $23,3 \%$ para a composição química do pólen recém coletado por $A$. mellifera e do pão-de-abelha (pólen armazenado na colônia), respectivamente. 


\subsubsection{Porcentagens (\%) de cinzas em amostras do pólen coletado por $A$. mellifera}

As porcentagens (\%) de cinzas em amostras do pólen coletado por A. mellifera não apresentaram variações estatisticamente significativas, com média de 2,87\% (máx. de 3,09 e mín. de 2,56) para os meses de março de 2000 e agosto de 1999, respectivamente (Tabela 10 ).

Tabela 10. Porcentagens (\%) de cinzas em amostras do pólen coletado em colméias de $A$. mellifera com coletores de pólen intermitentemente instalados, em Piracicaba, SP. *

\begin{tabular}{|c|c|c|c|c|c|c|c|c|}
\hline \multirow[b]{2}{*}{ Anos } & \multirow[b]{2}{*}{ Meses } & \multicolumn{5}{|c|}{ Colméias } & \multirow[b]{2}{*}{ Médias } & \\
\hline & & 1 & 2 & 3 & 4 & 5 & & \\
\hline \multirow{10}{*}{1999} & Março & 2,89 & 3,09 & 2,84 & 2,55 & 2,80 & 2,83 & \\
\hline & Abril & 2,77 & 2,79 & 2,83 & 2,84 & 2,75 & 2,80 & $\mathbf{a}$ \\
\hline & Maio & 2,91 & 2,87 & 2,72 & 2,82 & 2,92 & 2,85 & a \\
\hline & Junho & 3,11 & 2,77 & 2,76 & 2,82 & 2,86 & 2,86 & a \\
\hline & Julho & 2,73 & 2,88 & 2,83 & 2,87 & 2,76 & 2,81 & $\mathbf{a}$ \\
\hline & Agosto & 2,39 & 2,43 & 2,91 & 2,27 & 2,78 & 2,56 & $\mathbf{a}$ \\
\hline & Setembro & 3,02 & 3,72 & 2,96 & 2,88 & 2,82 & 3,08 & $\mathbf{a}$ \\
\hline & Outubro & 3,20 & 3,13 & 2,70 & 2,89 & 2,90 & 2,96 & $\mathbf{a}$ \\
\hline & Novembro & 3,76 & 3,41 & 2,57 & 2,87 & 2,62 & 3,05 & a \\
\hline & Dezembro & * & 3,14 & 2,59 & 2,47 & 2,97 & 2,79 & $\mathbf{a}$ \\
\hline \multirow{3}{*}{2000} & Janeiro & $*$ & 2,94 & 2,64 & 2,65 & 3,08 & 2,83 & $\mathbf{a}$ \\
\hline & Fevereiro & * & 2,90 & 2,71 & 2,57 & 3,21 & 2,85 & $\mathbf{a}$ \\
\hline & Março & * & 2,71 & 2,88 & 3,46 & 3,31 & 3,09 & a \\
\hline
\end{tabular}

Médias seguidas por letras distintas diferem estatisticamente entre si, em nivel de $5 \%$ de significância, pelo teste de Tukey. *A partir de 11/12/99 foram utilizadas 4 colméias devido ao abandono de um enxame. Coeficiente de variação igual a $8,91 \%$.

Os resultados obtidos apresentaram pequenas variabilidades nas médias das porcentagens (\%) de cinzas durante os meses do ano. Vários autores também encontraram pequenas variações nos teores observados: Almeida-Muradian \& Presoto (2000) 2,18 \pm 0,65\%; Costa et al. (2000) 0,94\%; Vivino \& Palmer (1944) 2,66\%; Funari et al. (1998a) 2,6\%; Avila (1980) 6\%. No entanto, outros autores, encontraram grandes variações nos teores observados: Ochoa (1980) de 1 a 7\%; Sampaio (1991) de 1,58\% a 3,61\%; Todd \& Bretherick (1942) de 0,91\% a 6,36\% (média de 2,70\%); Youssef et al. (1978) de 2,7\% a 5,7\%; com altos teores de $\mathrm{K}$, $\mathrm{Ca}$ e $\mathrm{Mg}$, moderados teores de $\mathrm{Fe}, \mathrm{Na}$ e $\mathrm{Mn}$, e traços de $\mathrm{Zn}$ e $\mathrm{Cu}$. 
Herbert Jr. \& Shimanuki (1978) estudaram a composição química do pólen recém coletado por $A$. mellifera e do pão-de-abelha (pólen armazenado na colônia). Obtendo o teor médio de 3,2\% para o recém coletado e 2,8\% para o armazenado.

Herbert Jr. \& Miller-Ihli (1987) atribuíram as grandes variações nos teores dos minerais nos pólens das plantas utilizadas por $A$. mellifera, provavelmente, às fontes florais e às condições do solo nas quais o pólen tinha sido produzido. Já Van Ass et al. (2000) afirmaram que estas alterações devem estar associadas às diferentes disponibilidades de alimento na natureza, tanto na produção como no conteúdo dos minerais.

\subsubsection{Porcentagens (\%) de umidade em amostras do pólen coletado por $A$. mellifera}

As porcentagens (\%) de umidade em amostras do pólen coletado por $A$. mellifera apresentaram variações estatisticamente significativas, com média de $23,65 \%$ (máx. de 33,18 e mín. de 16,84) para os meses de janeiro de 2000 e fevereiro de 2000 , respectivamente (Tabela 11 )

Tabela 11. Porcentagens (\%) de umidade em amostras do pólen coletado em colméias de A. mellifera com coletores de pólen intermitentemente instalados, em Piracicaba, SP. *

\begin{tabular}{|c|c|c|c|c|c|c|c|}
\hline \multirow[b]{2}{*}{ Anos } & \multirow[b]{2}{*}{ Meses } & \multicolumn{5}{|c|}{ Colméias } & \multirow[b]{2}{*}{ Médias } \\
\hline & & 1 & 2 & 3 & 4 & 5 & \\
\hline \multirow{10}{*}{1999} & Marco & 19,99 & 23,82 & 32,42 & 22,24 & 30,34 & $25,76 \mathrm{abc}$ \\
\hline & Abril & 9,71 & 19,35 & 29,35 & 24,01 & 32,58 & $23,00 \quad b c$ \\
\hline & Maio & 15,00 & 22,42 & 24,16 & 28,70 & 24,53 & $22,96 \quad b c$ \\
\hline & Junho & 18,38 & 20,98 & 18,24 & 21,48 & 29,59 & $21,73 \quad b c$ \\
\hline & Julho & 17,52 & 20,97 & 20,14 & 22,58 & 26,71 & 21,58 bc \\
\hline & Agosto & 23,11 & 20,61 & 21,50 & 19,57 & 25,88 & $22,14 \quad b c$ \\
\hline & Setembro & 21,24 & 24,89 & 24,62 & 26,12 & 25,57 & $24,49 \quad b c$ \\
\hline & Outubro & 16,91 & 18,01 & 18,24 & 20,26 & 21,79 & 19,04 \\
\hline & Novembro & 25,81 & 25,76 & 27,93 & 30,57 & 29,98 & $28,01 \quad a b$ \\
\hline & Dezembro & 22,14 & 27,87 & 25,09 & 27,10 & 25,12 & $25,47 \mathrm{abc}$ \\
\hline \multirow{3}{*}{2000} & Janeiro & $*$ & 35,21 & 27,92 & 35,27 & 34,31 & 33,18 a \\
\hline & Fevereiro & $*$ & 15,07 & 18,76 & 15,72 & 17,82 & 16,84 \\
\hline & Março & * & 22,16 & 24,08 & 24,38 & 21,71 & $23,08 \quad b c$ \\
\hline
\end{tabular}

Médias seguidas por letras distintas diferem estatisticamente entre si, em nível de $5 \%$ de significância, pelo teste de Tukey. *A partir de 11/12/99 foram utilizadas 4 colméias devido ao abandono de um enxame. Coeficiente de variação igual a $16,79 \%$. 
Os resultados obtidos apresentaram grandes variabilidades nas médias das porcentagens (\%) de umidade durante os meses do ano. Este fato é explicado pelo pólen ser um material altamente higroscópico, ou seja, absorve a umidade atmosférica com grande facilidade, sendo portanto grandemente afetada pelas condições do tempo. Vários autores também encontraram grandes variações nos teores observados: Day et al. (1990) de 16,8\% a 25,9\%; Todd \& Bretherick (1942) de 7,01\% a 16,23\% (média de 11,16\%); Sampaio (1991) de 2,61\% a 11,06\%; Costa et al. (2000) 27,53\%; Funari et al. (1998a) 24,1\%; Vivino \& Palmer (1944) 23,89\%; Ochoa (1980) de 12 a 20\%. AlmeidaMuradian \& Presoto (2000) 9,21 $\pm 1,45 \%$ para o pólen desidratado encontrado no comércio e o valor reportado por Avila (1980) de 4\% deve tratar-se de material para o mesmo fim.

Já Herbert Jr. \& Shimanuki (1978) estudaram a composição química do pólen recém coletado por $A$. mellifera e do pão-de-abelha (pólen armazenado na colônia) e obtiveram $24,3 \%$ e $23,8 \%$ para os dois itens avaliados, respectivamente.

\subsubsection{Porcentagens (\%) de resíduo seco em amostras do pólen coletado por $A$. mellifera}

As porcentagens (\%) de resíduo seco em amostras do pólen coletado por $A$. mellifera, apresentaram variações estatisticamente significativas, com média de $76,35 \%$ (máx. de 83,16 e mín. de 66,82) para os meses de fevereiro de 2000 e janeiro de 2000 , respectivamente (Tabela 12). 
Tabela 12. Porcentagens (\%) de resíduo seco em amostras do pólen coletado em colméias de $A$. mellifera com coletores de pólen intermitentemente instalados, em Piracicaba, SP. *

\begin{tabular}{|c|c|c|c|c|c|c|c|}
\hline \multirow[b]{2}{*}{ Anos } & \multirow[b]{2}{*}{ Meses } & \multicolumn{5}{|c|}{ Colméias } & \multirow[b]{2}{*}{ Médias } \\
\hline & & 1 & 2 & 3 & 4 & 5 & \\
\hline \multirow{10}{*}{1999} & Março & 80,01 & 76,18 & 67,58 & 77,76 & 69,66 & $74,24 \quad b c$ \\
\hline & Abril & 90,29 & 80,65 & 70,65 & 75,99 & 67,42 & $77,00 \mathrm{abc}$ \\
\hline & Maio & 85,00 & 77,58 & 75,84 & 71,31 & 75,47 & $77,04 \mathrm{abc}$ \\
\hline & Junho & 81,62 & 79,02 & 82,76 & 78,52 & 69,91 & $78,37 \mathrm{abc}$ \\
\hline & Julho & 82,49 & 79,03 & 79,86 & 77,42 & 73,54 & $78,47 \mathrm{abc}$ \\
\hline & Agosto & 76,89 & 79,39 & 78,50 & 80,43 & 74,12 & $77,86 \mathrm{abc}$ \\
\hline & Setembro & 78,76 & 75,11 & 75,38 & 73,88 & 74,43 & $75,51 \quad b c$ \\
\hline & Outubro & 83,09 & 81,99 & 81,76 & 79,74 & 78,21 & $80,96 \mathrm{ab}$ \\
\hline & Novembro & 74,19 & 74,37 & 72,07 & 69,43 & 70,02 & 72,02 \\
\hline & Dezembro & 77,86 & 72,13 & 74,91 & 72,90 & 74,88 & $74,53 \quad b c$ \\
\hline \multirow{3}{*}{2000} & Janeiro & * & 64,79 & 72,09 & 64,73 & 65,69 & 66,82 \\
\hline & Fevereiro & $*$ & 84,93 & 81,25 & 84,29 & 82,18 & 83,16 a \\
\hline & Março & * & 77,85 & 75,93 & 75,62 & 78,30 & $76,92 \mathrm{abc}$ \\
\hline
\end{tabular}

Médias seguidas por letras distintas diferem estatisticamente entre si, em nivel de $5 \%$ de significância, pelo teste de Tukey. *A partir de 11/12/99 foram utilizadas 4 colméias devido ao abandono de um enxame. Coeficiente de variação igual a $4,71 \%$.

Os resultados obtidos apresentaram grandes variabilidades nas médias das porcentagens (\%) de resíduo seco durante os meses do ano. Este fato também é explicado pelo pólen ser um material altamente higroscópico, ou seja, absorve a umidade atmosférica com grande facilidade. Sendo, portanto, seus valores grandemente afetados pelas condições meteorológicas. Por exemplo, Costa et al. (2000) $72,47 \pm$ 3,93\%; Vivino \& Palmer (1944) 76,11\%; Funari et al. (1998a) 75,9\%.

Já Herbert Jr. \& Shimanuki (1978) estudaram a composição química do pólen recém coletado por $A$. mellifera e do pão-de-abelha (pólen armazenado na colônia), obtendo $75,7 \%$ e $76,2 \%$, respectivamente.

\subsubsection{Porcentagens (\%) de lipídios em amostras do pólen coletado por $A$. mellifera}

As porcentagens (\%) de lipídios em amostras do pólen coletado por A. mellifera apresentaram variações estatisticamente significativas, com média de 3,57\% (máx. de 5,14 e mín. de 2,25) para os meses de novembro de 1999 e abril de 1999, respectivamente (Tabela 13). 
Tabela 13. Porcentagens (\%) de lipídios em amostras do pólen coletado em colméias de A. mellifera com coletores de pólen intermitentemente instalados, em Piracicaba, SP. *

\begin{tabular}{|c|c|c|c|c|c|c|c|c|}
\hline \multirow[b]{2}{*}{ Anos } & \multirow[b]{2}{*}{ Meses } & \multicolumn{5}{|c|}{ Colméias } & \multirow[b]{2}{*}{ Médias } & \\
\hline & & 1 & 2 & 3 & 4 & 5 & & \\
\hline \multirow{10}{*}{1999} & Marco & 1,98 & 3,14 & 2,76 & 2,20 & 2,12 & 2,44 & $\mathrm{fg}$ \\
\hline & Abril & 2,22 & 2,07 & 2,09 & 2,50 & 2,39 & 2,25 & $\mathrm{~g}$ \\
\hline & Maio & 3,46 & 2,70 & 3,12 & 3,25 & 3,27 & 3,16 & defg \\
\hline & Junho & 3,29 & 3,28 & 2,82 & 2,52 & 2,86 & 2,95 & defg \\
\hline & Julho & 3,94 & 3,78 & 4,24 & 3,68 & 3,79 & 3,89 & bcde \\
\hline & Agosto & 3,73 & 4,69 & 5,07 & 4,45 & 6,30 & 4.85 & $a b$ \\
\hline & Setembro & 4,34 & 3,25 & 4,08 & 4,91 & 4,81 & 4.28 & $a b c$ \\
\hline & Outubro & 3,15 & 3,35 & 3,15 & 4,13 & 3,18 & 3,39 & cdef \\
\hline & Novembro & 4,95 & 5,15 & 4,32 & 5,41 & 5,86 & 5,14 & a \\
\hline & Dezembro & $*$ & 2,87 & 2,25 & 3,13 & 3,20 & 2.86 & efg \\
\hline \multirow{3}{*}{2000} & Janeiro & $*$ & 4,01 & 4,32 & 4,00 & 3,67 & 4.00 & bed \\
\hline & Fevereiro & $*$ & 3,45 & 3,23 & 4,01 & 3,53 & 3.55 & cde \\
\hline & Março & $*$ & 4,36 & 4,07 & 2,93 & 3,17 & 3.63 & cde \\
\hline
\end{tabular}

Médias seguidas por letras distintas diferem estatisticamente entre si, em nível de $5 \%$ de significância, pelo teste de Tukey. *A partir de 11/12/99 foram utilizadas 4 colméias devido ao abandono de um enxame. Coeficiente de variação igual a $13,44 \%$.

Os resultados obtidos apresentaram grandes variabilidades nas médias das porcentagens (\%) de lipídios durante os meses do ano. Este fato pode ser explicado além das variações que ocorrem nas composições das plantas de origem dos pólens coletados como resultado também das necessidades diferenciadas das abelhas em determinados componentes que estão presentes nos materiais coletados. Os resultados obtidos por diversos autores também são muito varáveis: Vivino \& Palmer (1944) 3,34\%; Sampaio (1991) de 2,17\% a 5,63\%; Funari et al. (1998a) 5,1\%; Avila (1980) 5\%; Todd \& Bretherick (1942) de 0,94\% a 14,44\% (média de 4,96\%); Day et al. (1990) de 0,17\% a 13,40\%; Almeida-Muradian \& Presoto (2000) 7,46 $\pm 2,81 \%$; Singh et al. (1999) de $11,6 \%$ a $20,3 \%$.

Já Herbert Jr. \& Shimanuki (1978) estudaram a composição química do pólen recém coletado por $A$. mellifera e do pão-de-abelha (pólen armazenado na colônia) e encontraram $4,9 \%$ de lipídios no recém coletado e $5,4 \%$ para o armazenado na colônia. 


\subsubsection{Determinação eletrométrica do $\mathrm{pH}$ em amostras do pólen coletado por $\boldsymbol{A}$. mellifera}

As determinações eletrométricas do $\mathrm{pH}$ em amostras do pólen coletado por $A$. mellifera apresentaram variações estatisticamente significativas, com média de 5,08 (máx. de 5,32 e mín. de 4,78) para os meses de junho de 1999 e dezembro de 1999 , respectivamente (Tabela 14).

Tabela 14. Resultados da determinação eletrométrica do $\mathrm{pH}$ em amostras do pólen coletado em colméias de $A$. mellifera com coletores de pólen intermitentemente instalados, em Piracicaba, SP. *

\begin{tabular}{|c|c|c|c|c|c|c|c|}
\hline \multirow[b]{2}{*}{ Anos } & \multirow[b]{2}{*}{ Meses } & \multicolumn{5}{|c|}{ Colméias } & \multirow[b]{2}{*}{ Médias } \\
\hline & & 1 & 2 & 3 & 4 & 5 & \\
\hline & Março & 5,08 & 4,86 & 4,71 & 4,97 & 5,07 & $4,94 \mathrm{ab}$ \\
\hline \multirow{9}{*}{1999} & Abril & 5,09 & 5,23 & 4,92 & 5,34 & 5,42 & $5,20 \mathrm{ab}$ \\
\hline & Maio & 4,97 & 5,20 & 5,25 & 5,32 & 5,36 & $5,22 \quad a b$ \\
\hline & Junho & 5,05 & 5,09 & 5,44 & 5,45 & 5,57 & 5,32 a \\
\hline & Julho & 5,37 & 5,33 & 5,21 & 5,24 & 5,33 & 5,29 a \\
\hline & Agosto & 5,41 & 4,86 & 5,02 & 4,78 & 4,76 & $4,97 \mathrm{ab}$ \\
\hline & Setembro & 5,51 & 5,17 & 4,90 & 4,88 & 5,14 & $5,12 a b$ \\
\hline & Outubro & 5,03 & 4,89 & 5,19 & 4,95 & 4,90 & $4,99 a b$ \\
\hline & Novembro & 5,19 & 5,29 & 4,89 & 4,73 & 4,79 & $4,98 \mathrm{ab}$ \\
\hline & Dezembro & * & 4,81 & 4,74 & 4,89 & 4,67 & $4,78 \quad b$ \\
\hline \multirow{3}{*}{2000} & Janeiro & * & 4,98 & 5,52 & 5,35 & 5,03 & $5,22 a b$ \\
\hline & Fevereiro & * & 5,04 & 4,95 & 5,01 & 4,92 & $4,98 \mathrm{ab}$ \\
\hline & Março & * & 5,53 & 5,24 & 4,33 & 4,80 & $4,97 \mathrm{ab}$ \\
\hline
\end{tabular}

Médias seguidas por letras distintas diferem estatisticamente entre si, em nível de $5 \%$ de significância, pelo teste de Tukey. *A partir de 11/12/99 foram utilizadas 4 colméias devido ao abandono de um enxame. Coeficiente de variação igual a $4,33 \%$.

Os resultados obtidos apresentaram grandes variabilidades nas médias do $\mathrm{pH}$ durante os meses do ano. No entanto em todas as análises realizadas obtiveram-se valores inferiores a 7 indicando que o material é ácido. Poucos autores divulgaram resultados obtidos para os valores de pH do pólen: Sampaio (1991) de 4,60 a 5,90; Herbert Jr. \& Shimanuki (1978) estudaram a composição química do pólen recém coletado por $A$. mellifera e do pão-de-abelha (pólen armazenado na colônia), encontrando os seguintes valores de $\mathrm{pH}: 4,8$ e 4,1, respectivamente. Essa redução é explicada tendo-se em vista que a fermentação a qual o pólen sofre durante o armazenamento resulta em ácidos que ocasionam uma redução no valor do $\mathrm{pH}$. 


\subsubsection{Acidez titulável em amostras do pólen coletado por $\boldsymbol{A}$. mellifera}

A acidez titulável (mEq/kg de pólen) em amostras do pólen coletado por $A$. mellifera apresentaram variações estatisticamente signifícativas, com média de 20,66 $\mathrm{mEq} / \mathrm{kg}$ de pólen (mín. de 19,51 e máx. de 22,55) para os meses de março de 1999 e abril de 1999, respectivamente (Tabela 15).

Tabela 15. Acidez titulável ( $\mathrm{mEq} / \mathrm{kg}$ de pólen) de amostras coletadas em colméias de $A$. mellifera com coletores de pólen intermitentemente instalados, em Piracicaba, SP. *

\begin{tabular}{|c|c|c|c|c|c|c|c|}
\hline \multirow[b]{2}{*}{ Anos } & \multirow[b]{2}{*}{ Meses } & \multicolumn{5}{|c|}{ Colméias } & \multirow[b]{2}{*}{ Médias } \\
\hline & & 1 & 2 & 3 & 4 & 5 & \\
\hline \multirow{10}{*}{1999} & Março & 19,48 & 19,32 & 19,12 & 20,46 & 19,15 & 19,51 \\
\hline & Abril & 22,44 & 22,76 & 23,08 & 21,90 & 22,56 & 22,55 a \\
\hline & Maio & 20,97 & 23,05 & 22,53 & 21,39 & 21,48 & $21,88 \mathrm{abc}$ \\
\hline & Junho & 19,92 & 22,40 & 21,44 & 21,30 & 21,30 & $21,27 \mathrm{abc}$ \\
\hline & Julho & 22,16 & 22,44 & 23,68 & 20,18 & 22,86 & $22,26 \mathrm{ab}$ \\
\hline & Agosto & 20,96 & 20,11 & 22,84 & 22,11 & 22,91 & 21,79 abc \\
\hline & Setembro & 20,44 & 17,94 & 19,53 & 21,94 & 21,04 & $20,18 \mathrm{abc}$ \\
\hline & Outubro & 17,52 & 20,45 & 22,92 & 19,92 & 22,50 & $20,66 \mathrm{abc}$ \\
\hline & Novembro & 21,57 & 18,81 & 20,59 & 18,88 & 19,78 & $19,93 \mathrm{bc}$ \\
\hline & Dezembro & 21,36 & 21,69 & 20,10 & 22,09 & 21,21 & $21,29 \mathrm{abc}$ \\
\hline \multirow{3}{*}{2000} & Janeiro & $*$ & 21,87 & 21,41 & 21,52 & 18,13 & $20,73 \mathrm{abc}$ \\
\hline & Fevereiro & $*$ & 20,01 & 22,23 & 19,56 & 20,59 & $20,60 \mathrm{abc}$ \\
\hline & Março & * & $20 ; 91$ & 20,08 & 19,30 & 18,96 & $19,81 \quad b c$ \\
\hline
\end{tabular}

Médias seguidas por letras distintas diferem estatisticamente entre si, em nivel de $5 \%$ de significância, pelo teste de Tukey. *A partir de 11/12/99 foram utilizadas 4 colméias devido ao abandono de um enxame. Caeficiente de variação igual a $5,63 \%$.

Os resultados obtidos apresentaram grandes variabilidades nas médias da acidez titulável durante os meses do ano. Este fato pode ser explicado pelas variações que ocorrem nas composições das plantas de origem dos pólens coletados. 


\subsubsection{Porcentagens (\%) de açúcares totais em amostras do pólen coletado por $A$. mellifera}

As porcentagens (\%) de açúcares totais em amostras do pólen coletado por $A$. mellifera de março de 1999 a março de 2000 apresentou grandes variações estatisticamente significativas, com média de $28,44 \%$ (mín. de 21,71 e máx. de 33,93) para os meses de março de 2000 e julho de 1999 , respectivamente (Tabela 16).

Tabela 16. Porcentagens (\%) de açúcares totais em amostras do pólen coletado em colméias de $A$. mellifera com coletores de pólen intermitentemente instalados, em Piracicaba, SP. *

\begin{tabular}{|c|c|c|c|c|c|c|c|}
\hline \multirow[b]{2}{*}{ Anos } & \multirow[b]{2}{*}{ Meses } & \multicolumn{5}{|c|}{ Colméias } & \multirow[b]{2}{*}{ Médias } \\
\hline & & 1 & 2 & 3 & 4 & 5 & \\
\hline \multirow{10}{*}{1999} & Março & 30,30 & 29,77 & 31,48 & 26,13 & 30,24 & 31,11 abc \\
\hline & Abril & 28,24 & 25,68 & 29,03 & 27,33 & 27,36 & $27,53 \mathrm{abcd}$ \\
\hline & Maio & 32,10 & 29,97 & 28,92 & 28,18 & 35,96 & $31,02 \mathrm{abcd}$ \\
\hline & Junho & 27,54 & 27,10 & 22,55 & 27,12 & 25,89 & $26.04 \mathrm{abcd}$ \\
\hline & Julho & 18,85 & 20,01 & 16,10 & 28,52 & 25,06 & 21.71 \\
\hline & Agosto & 25,92 & 30,29 & 30,58 & 24,55 & 14,51 & 25.17 \\
\hline & Setembro & 23,00 & 27,73 & 29,99 & 30,72 & 26,39 & $27,56 \mathrm{abcd}$ \\
\hline & Outubro & 28,41 & 19,00 & 24,75 & 28,10 & 27,17 & 25,48 bcd \\
\hline & Novembro & 17,90 & 31,03 & 29,24 & 24,39 & 29,98 & $26,51 \mathrm{abcd}$ \\
\hline & Dezembro & 25,75 & 20,51 & 33,00 & 29,68 & 32,45 & 28,28 abcd \\
\hline \multirow{3}{*}{2000} & Janeiro & * & 34,11 & 29,54 & 31,90 & 38,29 & $33,46 a b$ \\
\hline & Fevereiro & * & 33,13 & 34,11 & 31,04 & 35,43 & $33,43 a b$ \\
\hline & Março & $*$ & 34,65 & 33,19 & 35,47 & 32,43 & $33.93 \mathbf{a}$ \\
\hline
\end{tabular}

Médias seguidas por letras distintas diferem estatisticamente entre si, em nível de $5 \%$ de significancia, pelo teste de Tukey. "A partir de 11/12/99 foram utilizadas 4 colméias devido ao abandono de um enxame. Coeficiente de variação igual a $13,19 \%$.

Os resultados obtidos apresentaram grandes variabilidades nas médias das porcentagens (\%) de açúcares totais durante os meses do ano. Este fato pode ser explicado pelas variações que ocorrem nas composições das plantas de origem dos pólens coletados. Apesar dos valores elevados de açúcares encontrados as abelhas têm necessidade de consumir o mel como fonte principal de carboidratos, tendo-se em vista que este é mais fácil e rapidamente assimilado por seu metabolismo.

Os resultados obtidos por diversos autores também são muito variáveis e podem ser expressos em carboidratos totais: Ochoa (1980) de 25 a 40\%; Avila (1980) 50\%; Almeida-Muradian \& Presoto (2000) 56,50 $\pm 10,11 \%$; Day et al. (1990) de 12,6\% a 
$29,6 \%$ (de $11,1 \%$ a $25,7 \%$ de açúcares redutores). Expressos em açúcares redutores e não redutores: Todd \& Bretherick (1942) açúcares redutores: de $18,82 \%$ a $41,21 \%$ (média de 25,71\%), açúcares não redutores média de 2,71\%; Sampaio (1991) açúcares redutores: de $19,40 \%$ a $28,25 \%$, açúcares não redutores: de $1,07 \%$ a 5,55\%. Já Herbert Jr. \& Shimanuki (1978) estudaram a composição química do pólen recém coletado por A. mellifera e do pão-de-abelha (pólen armazenado na colônia). Para o pólen recém coletado o teor médio para açúcares redutores foi de $20,7 \%$ e para açúcares não redutores foi de $2,1 \%$. Para o pólen armazenado na colônia o teor médio para açúcares redutores foi de $27,9 \%$ e para açúcares não redutores foi de $2,5 \%$.

\subsection{Correlações entre os dados biológicos e as análises físico-químicas}

Os resultados obtidos para as correlações entre os dados biológicos e as análises físico-químicas do pólen coletado em colméias de $A$. mellifera com coletores intermitantemente instalados encontram-se na Tabela 17.

Tabela 17. Correlações entre os dados biológicos e as análises fisico-químicas do pólen coletado em colméias de $A$. mellifera com coletores intermitantemente instalados.

\begin{tabular}{|c|c|c|c|c|}
\hline \multicolumn{5}{|c|}{ Areas $\left(\mathrm{cm}^{2}\right)$ ocupadas com } \\
\hline & Mel & Pólen & Ovos & $\mathrm{CDO}^{* *}$ \\
\hline Mel & 1 & $0,0074\left(r^{2}=0,52\right)$ & $0,0005\left(r^{2}=0,65\right)$ & * \\
\hline Ovos & * & $0,0055\left(r^{2}=0,54\right)$ & 1 & $*$ \\
\hline $\mathrm{CDO}^{* *}$ & $0,0001\left(r^{2}=0,69\right)$ & $0,0001\left(\mathrm{r}^{2}=0,84\right)$ & $0,0033\left(r^{2}=0,57\right)$ & 1 \\
\hline $\mathrm{COO}^{* * *}$ & $0,0002\left(r^{2}=0,67\right)$ & $0,0027\left(r^{2}=0,57\right)$ & $0,0045\left(r^{2}=0,55\right)$ & $0,0001\left(r^{2}=0,75\right)$ \\
\hline Óvulos & $*$ & $0,0001\left(r^{2}=-0,77\right)$ & $0,0055\left(r^{2}=-0,54\right)$ & $0,0001\left(r^{2}=-0,70\right)$ \\
\hline
\end{tabular}

* Correlações não significativas

** Crias desoperculadas que darão origem as operárias

*** Crias operculadas que darão origem as operárias 
Ocorreram correlações positivas entre as áreas $\left(\mathrm{cm}^{2}\right)$ com pólen e as áreas com mel, ovos, crias desoperculadas e operculadas que darão origem as operárias. Foram verificadas correlações negativas entre as áreas $\left(\mathrm{cm}^{2}\right)$ com pólen e as áreas com óvulos.

Observou-se correlações positivas entre as áreas $\left(\mathrm{cm}^{2}\right)$ com mel e as áreas com ovos, crias desoperculadas e operculadas que darão origem as operárias. Foram verificadas correlações negativas entre as áreas $\left(\mathrm{cm}^{2}\right)$ com mel e as áreas com óvulos.

As áreas $\left(\mathrm{cm}^{2}\right)$ com crias operculadas que darão origem a zangões apresentaram correlações positivas com as áreas $\left(\mathrm{cm}^{2}\right)$ de crias desoperculadas que darão origem a zangões.

Para as áreas $\left(\mathrm{cm}^{2}\right)$ com óvulos foram verificadas correlações negativas com as áreas $\left(\mathrm{cm}^{2}\right)$ de ovos, crias desoperculadas e operculadas que darão origem as operárias.

Verificou-se para as áreas $\left(\mathrm{cm}^{2}\right)$ crias operculadas que darão origem as operárias correlações positivas com as áreas $\left(\mathrm{cm}^{2}\right)$ de ovos e crias operculadas que darão origem as operárias.

As áreas $\left(\mathrm{cm}^{2}\right)$ de crias desoperculadas que darão origem as operárias apresentaram correlações positivas com as áreas $\left(\mathrm{cm}^{2}\right)$ de ovos.

\subsection{Eficiência (\%) do coletor de pólen (chapa com perfurações de 4,00 mm)}

A eficiência (\%) dos coletores de pólen (chapa com perfurações de 4,00 mm) permanentemente instalados em colméias de Apis mellifera, de 19/06/00 a 20/07/00, foi decrescente, reduzindo-se a $2 / 3$ da eficiência inicial após 30 dias da sua instalação (média de 68,23\%, variando de $82,5 \%$ a 59,0\%) (Tabela 18 ). 
Tabela 18. Eficiência (\%) do coletor de pólen (chapa com perfurações de 4,00 mm) usado em colméias de $A$. mellifera de 19/06/00 a 20/07/00, em Piracicaba, SP.

\begin{tabular}{|c|c|c|c|c|c|c|c|}
\hline$\overline{\text { Avaliação }}$ & Eficiência (\%) & Avaliação & Eficiência (\%) & Avaliação & Eficiência (\%) & Avaliação & Eficiência (\%) \\
\hline 1 & 82,5 & 9 & 76,5 & 17 & 62,5 & 25 & 61,5 \\
\hline 2 & 81,5 & 10 & 74,0 & 18 & 63,0 & 26 & 58,5 \\
\hline 3 & 81,0 & 11 & 74,0 & 19 & 62,5 & 27 & 58,0 \\
\hline 4 & 78,5 & 12 & 72,5 & 20 & 63,0 & 28 & 61,0 \\
\hline 5 & 77,5 & 13 & 68,5 & 21 & 64,5 & 29 & 57,5 \\
\hline 6 & 79,0 & 14 & 71,5 & 22 & 60,0 & 30 & 68,0 \\
\hline 7 & 75,5 & 15 & 68,5 & 23 & 64,0 & 31 & 62,5 \\
\hline 8 & 75,5 & 16 & 64,0 & 24 & 57,5 & 32 & 59,0 \\
\hline \multicolumn{7}{|c|}{ Média da eficiência das 32 avaliações } & 68,23 \\
\hline
\end{tabular}

A redução na eficiência do coletor coincide com os valores observados por Ochoa (1980) em abelhas européias. No entanto, Levin \& Loper (1984) utilizando o mesmo tipo de coletor de pólen obtiveram $33 \%$ de eficiência em um local e $66 \%$ em outro.

4.5 Granulometria (malhas de 0,$106 ; 0,300 ; 0,500 ; 1,00$ e $2,00 \mathrm{~mm} / \mu \mathrm{m}$ ) do pólen coletado por $A$. mellifera

Os resultados obtidos para a determinação da granulometria (malhas de 0,106 ; $0,300 ; 0,500 ; 1,00$ e $2,00 \mathrm{~mm} / \mu \mathrm{m})$ do pólen coletado por $A$. mellifera com coletores permanentemente instalados, de 19/06/2000 a 19/07/2000 encontram-se na Tabela 19. 
Tabela 19. Determinação média (\%) da granulometria (malhas de 0,$106 ; 0,300 ; 0,500$; $1,00$ e $2,00 \mathrm{~mm} / \mu \mathrm{m})$ do pólen coletado por $A$. mellifera, de $19 / 06 / 2000$ a 19/07/2000, em Piracicaba - SP. *

\begin{tabular}{crrrrr}
\hline & \multicolumn{5}{c}{ Malhas $(\mathrm{mm} / \mu \mathrm{m})$} \\
\cline { 2 - 6 } Meses & $\mathbf{0 , 1 0 6}$ & $\mathbf{0 , 3 0 0}$ & \multicolumn{1}{c}{0,500} & \multicolumn{1}{c}{$\boldsymbol{1 , 0 0}$} & 2,00 \\
\cline { 2 - 6 } & 0,46 & 3,89 & 7,89 & 77,38 & 10,39 \\
& 0,59 & 1,74 & 5,60 & 81,75 & 10,32 \\
& 1,29 & 6,02 & 13,38 & 77,96 & 1,36 \\
& 0,91 & 3,55 & 10,33 & 75,16 & 10,05 \\
Junho/2000 & 0,43 & 2,06 & 8,46 & 82,05 & 6,99 \\
& 0,50 & 1,98 & 6,80 & 78,41 & 12,31 \\
& 0,18 & 7,33 & 11,62 & 70,15 & 10,72 \\
& 0,77 & 3,15 & 8,67 & 79,18 & 8,23 \\
& 0,66 & 2,90 & 8,45 & 79,74 & 8,25 \\
& 0,69 & 2,79 & 8,55 & 78,74 & 9,22 \\
& 0,32 & 1,61 & 5,48 & 83,17 & 9,42 \\
& 0,76 & 2,77 & 7,53 & 81,20 & 7,74 \\
& 0,56 & 2,38 & 9,30 & 82,10 & 5,66 \\
& 0,97 & 3,19 & 13,67 & 75,31 & 6,86 \\
& 0,68 & 2,60 & 10,43 & 81,92 & 4,37 \\
& 1,70 & 3,37 & 10,63 & 81,07 & 3,23 \\
& 0,82 & 3,16 & 9,14 & 83,69 & 3,19 \\
& 0,63 & 2,53 & 9,46 & 82,13 & 5,26 \\
& 1,47 & 1,80 & 7,17 & 83,41 & 6,16 \\
& 0,92 & 1,74 & 6,38 & 79,19 & 11,77 \\
& 0,32 & 1,29 & 4,76 & 78,47 & 15,16 \\
& 0,26 & 1,01 & 3,93 & 80,52 & 14,28 \\
& 0,60 & 2,45 & 7,18 & 81,17 & 8,60 \\
& 0,23 & 0,96 & 4,21 & 79,02 & 15,58 \\
& 0,35 & 1,61 & 5,88 & 79,99 & 12,17 \\
& 0,38 & 1,44 & 6,06 & 84,36 & 7,77 \\
& 0,51 & 2,12 & 7,54 & 82,60 & 7,23 \\
& 2,00 & 5,36 & 12,71 & 73,82 & 6,11 \\
& 0,43 & 3,13 & 10,04 & 71,82 & 14,58 \\
& 0,60 & 2,77 & 8,20 & 72,49 & 15,94 \\
& 1,09 & 5,47 & 18,85 & 66,90 & 7,68 \\
\hline \multirow{5yyyy}{*}{ Médias } & 0,61 & 2,33 & 7,63 & 79,62 & 9,81 \\
\hline
\end{tabular}

Observaram-se grandes variações entre as datas (de um dia para o seguinte) avaliadas, nas próprias colméias e entre colméias. Não foi verificado que a granulometria apresente uma tendência de diminuição no tamanho das cargas transportadas com o passar do tempo, como ocorreu com a eficiência do coletor. A grande maioria (aproximadamente 
$80 \%$ do total) do pólen coletado apresentou granulometria maior do $1,00 \mathrm{~mm} / \mu \mathrm{m}$ e menor do que $2,00 \mathrm{~mm} / \mu \mathrm{m}$.

Ochoa (1980) afirmou que as abelhas européias ao notarem que quando parte do pólen por elas coletado é retirado, as abelhas diminuem instintivamente o tamanho das bolotas que transportam conseguindo dessa maneira vencer o anteparo dos coletores de pólen.

4.6 A. mellifera transportando carga de pólen às $8: 00 \mathrm{~h}, 11: 00 \mathrm{~h}$ e 16:00h, com ou sem coletores permanentemente instalados

Os resultados obtidos para o número médio de $A$. mellifera transportando carga de pólen às $8: 00 \mathrm{~h}, 11: 00 \mathrm{~h}$ e 16:00h, em colméias com coletores permanentemente instalados, de 19/06/00 a 20/07/00 e sem, de 22/06/00 a 20/07/00 encontram-se na Tabela 20.

Tabela 20. Número médio de $A$. mellifera transportando carga de pólen às $8: 00 \mathrm{~h}, 11: 00 \mathrm{~h}$ e 16:00h, em colméias com coletores permanentemente instalados, de 19/06/00 a 20/07/00 e em colméias sem coletores, de 22/06/00 a 20/07/00, em Piracicaba, SP.

\begin{tabular}{crrrrrr}
\hline \multirow{2}{*}{ Meses } & \multicolumn{3}{c}{ Com coletores } & \multicolumn{3}{c}{ Sem coletores } \\
\cline { 2 - 7 } & $\mathbf{8 : 0 0 h}$ & $11: 00 \mathrm{~h}$ & $\mathbf{1 6 : 0 0 \mathrm { h }}$ & $\mathbf{8 : 0 0 h}$ & $11: 00 \mathrm{~h}$ & $\mathbf{1 6 : 0 0 \mathrm { h }}$ \\
\hline & 18,60 & 8,80 & 2,80 & - & - & - \\
& 11,40 & 8,20 & 1,40 & - & - & - \\
& 10,40 & 5,80 & 2,20 & - & - & - \\
Junho/2000 & 3,40 & 12,00 & 3,00 & 2,60 & 11,40 & 0,80 \\
& 0,60 & 10,00 & 2,40 & 0,40 & 1,60 & 1,20 \\
& 7,60 & 5,00 & 1,40 & 0,60 & 1,00 & 2,00 \\
& 3,80 & 1,80 & 1,20 & 0,40 & 1,00 & 1,20 \\
& 5,20 & 3,20 & 2,00 & 1,00 & 8,00 & 1,40 \\
& 5,40 & 3,00 & 0,80 & 2,80 & 3,60 & 1,00 \\
& 6,40 & 5,80 & 2,00 & 2,80 & 6,20 & 1,00 \\
& 4,00 & 3,60 & 2,00 & 1,20 & 10,00 & 3,00 \\
Julho/2000 & 0,60 & 1,20 & 3,00 & 1,20 & 0,20 & 2,00 \\
& 6,80 & 3,60 & 1,80 & 1,40 & 2,20 & 1,40 \\
& 8,00 & 4,40 & 2,80 & 7,60 & 1,80 & 2,20 \\
& 5,20 & 4,80 & 1,60 & 5,00 & 4,20 & 0,80
\end{tabular}


Tabela 20. Número médio de $A$. mellifera transportando carga de pólen às $8: 00 \mathrm{~h}, 11: 00 \mathrm{~h}$ e 16:00h, em colméias com coletores permanentemente instalados, de 19/06/00 a 20/07/00 e em colméias sem coletores, de 22/06/00 a 20/07/00, em Piracicaba, SP.

\begin{tabular}{crrrrrr}
\hline & \multicolumn{3}{c}{ Com coletores } & \multicolumn{3}{c}{ Sem coletores } \\
\cline { 2 - 7 } Meses & $\mathbf{8 : 0 0 h}$ & $11: 00 \mathrm{~h}$ & $\mathbf{1 6 : 0 0 h}$ & $\mathbf{8 : 0 0 h}$ & $11: 00 \mathrm{~h}$ & $\mathbf{1 6 : 0 0 \mathrm { h }}$ \\
\hline & $\mathbf{6 , 4 0}$ & 3,60 & 1,00 & 6,40 & 5,00 & 0,60 \\
& 0,20 & 5,20 & 1,80 & 0,20 & 5,60 & 1,20 \\
& 3,00 & 3,20 & 0,60 & 2,60 & 3,00 & 0,40 \\
Junho/2000 & 4,00 & 1,40 & 0,80 & 4,00 & 1,20 & 1,60 \\
& 5,20 & 2,60 & 0,80 & 5,40 & 1,80 & 0,20 \\
& 2,40 & 5,40 & 0,80 & 2,00 & 3,20 & 0,40 \\
& 5,80 & 3,20 & 0,60 & 5,80 & 1,20 & 0,00 \\
& 4,00 & 3,20 & 2,20 & 5,60 & 3,60 & 1,60 \\
& 2,80 & 3,80 & 1,40 & 2,00 & 7,00 & 1,60 \\
& 0,60 & 5,40 & 1,00 & 0,20 & 2,40 & 1,00 \\
& 1,40 & 4,40 & 1,00 & 1,60 & 4,20 & 1,00 \\
Julho/2000 & 5,60 & 3,80 & 0,60 & 5,20 & 3,00 & 0,00 \\
& 1,00 & 2,40 & 0,40 & 1,60 & 1,60 & 0,20 \\
& 0,00 & 3,00 & 0,80 & 0,00 & 1,40 & 1,00 \\
& 0,00 & 5,00 & 0,40 & 0,00 & 2,40 & 0,80 \\
& 1,00 & 2,40 & 0,40 & 1,00 & 1,20 & 0,20 \\
& 0,00 & 2,00 & 1,00 & 0,00 & 1,80 & 0,20 \\
\hline Médias & $3,64 \mathrm{a}$ & $4,16 \mathrm{a}$ & $\mathbf{1 , 3 6} \mathrm{b}$ & $2,03 \mathrm{~b}$ & $3,08 \mathrm{a}$ & $\mathbf{0 , 9 5 b}$ \\
\hline
\end{tabular}

Médias seguidas por letras distintas diferem estatisticamente entre si, em nivel de $5 \%$ de significância, pelo teste de Tukey.

Os resultados obtidos estão de acordo com a afirmação de Levin \& Loper (1984) de que nas colméias com coletores de pólen instalados as porcentagens de abelhas coletoras de pólen são maiores. Também verificaram que a quantidade de pólen armazenado foi menor nas colméias com coletores e segundo Fewell \& Winston (1992) essa redução na quantidade de pólen armazenado induz a um aumento na proporção de abelhas coletoras de pólen. 


\subsection{Pólen coletado (g) por $A$. mellifera em colméias com ou sem rainhas e com coletores permanentemente instalados}

Resultados obtidos para as quantidades (g) de pólen coletado, em colméias de $A$. mellifera com rainhas de 19/06/00 a 19/07/00 (Tabela 21) ou sem rainhas de 01/07/00 a 15/07/00 (Tabela 22), com coletores de pólen permanentemente instalados.

Tabela 21. Pólen coletado (g) por A. mellifera em colméias com rainhas e com coletores permanentemente instalados, de 19/06/00 a 19/07/00, em Piracicaba, SP.

\begin{tabular}{|c|c|c|c|c|c|c|}
\hline \multirow[b]{2}{*}{ Meses } & \multicolumn{5}{|c|}{ Colméias } & \multirow[b]{2}{*}{ Médias } \\
\hline & 1 & 2 & 3 & 4 & 5 & \\
\hline \multirow{12}{*}{ Junho/2000 } & 0,7583 & 3,6207 & 0,0472 & 1,3627 & 6,3096 & 2,4197 \\
\hline & 0,6515 & 2,6151 & 0,2282 & 1,7221 & 5,0104 & 2,0455 \\
\hline & 0,1678 & 2,9637 & 0,1124 & 1,2384 & 4,6573 & 1,8279 \\
\hline & 0,3590 & 16,0095 & 0,1973 & 1,0764 & 6,4481 & 4,8181 \\
\hline & 0,2436 & 19,8425 & 0,2627 & 0,7923 & 6,1315 & 5,4545 \\
\hline & 0,1742 & 19,9624 & 0,2567 & 0,9137 & 5,2355 & 5,3085 \\
\hline & 0,1945 & 15,3216 & 0,8589 & 1,7796 & 6,1755 & 4,8660 \\
\hline & 0,2381 & 18,9129 & 0,9557 & 2,2786 & 5,8012 & 5,6373 \\
\hline & 0,4610 & 28,4719 & 0,6132 & 3,0870 & 10,4316 & 8,6129 \\
\hline & 0,6553 & 25,0036 & 1,0534 & 2,6455 & 15,5865 & 8,9889 \\
\hline & 0,7797 & 32,3613 & 0,9096 & 4,0170 & 21,2601 & 11,8655 \\
\hline & 0,8376 & 26,4840 & 1,0081 & 3,5780 & 18,2065 & 10,0228 \\
\hline \multirow[t]{19}{*}{ Julho/2000 } & 1,9360 & 29,7722 & 2,1131 & 4,3195 & 22,4908 & 12,1263 \\
\hline & 1,7170 & 37,8470 & 1,5180 & 5,4712 & 19,1670 & 13,1440 \\
\hline & 1,4314 & 34,9024 & 1,3176 & 4,5949 & 15,2009 & 11,4894 \\
\hline & 1,4606 & 17,6757 & 0,4854 & 2,4425 & 10,3546 & 6,4838 \\
\hline & 1,4555 & 20,4870 & 0,4725 & 2,4256 & 12,6953 & 7,5072 \\
\hline & 1,3467 & 20,2433 & 0,3022 & 2,0847 & 9,2761 & 6,6506 \\
\hline & 3,6035 & 19,6176 & 0,7246 & 1,8778 & 10,2008 & 7,2049 \\
\hline & 9,2319 & 23,3360 & 0,6550 & 3,9534 & 14,4089 & 10,3170 \\
\hline & 15,0440 & 33,9171 & 0,7875 & 4,8454 & 12,0968 & 13,3382 \\
\hline & 14,7600 & 47,7100 & 1,3176 & 7,3000 & 14,7388 & 17,1653 \\
\hline & 13,5156 & 78,9949 & 1,2153 & 10,0173 & 19,4583 & 24,6403 \\
\hline & 4,6440 & 19,2103 & 0,5212 & 3,7850 & 9,5285 & 7,5378 \\
\hline & 4,9708 & 29,7714 & 0,4788 & 6,0384 & 11,9613 & 10,6441 \\
\hline & 4,1765 & 26,7684 & 0,5803 & 3,7967 & 8,3913 & 8,7426 \\
\hline & 3,9470 & 19,5260 & 0,6628 & 2,8850 & 7,8500 & 6,9742 \\
\hline & 1,7962 & 9,4850 & 0,3460 & 1,8614 & 4,0538 & 3,5085 \\
\hline & 0,7368 & 4,6035 & 0,1157 & 0,5303 & 0,8465 & 1,3666 \\
\hline & 1,4280 & 6,9090 & 0,1164 & 0,8354 & 1,0138 & 2,0605 \\
\hline & 0,3073 & 1,6460 & 0,0250 & 0,1508 & 0,3445 & 0,4947 \\
\hline Médias & & & & & & 7,03 \\
\hline
\end{tabular}


Tabela 22. Pólen coletado (g) por $A$. mellifera em colméias sem rainhas e com coletores permanentemente instalados, de 01/07/00 a 15/07/00, em Piracicaba, SP.

\begin{tabular}{|c|c|c|c|c|c|c|}
\hline \multirow[b]{2}{*}{ Mês } & \multicolumn{5}{|c|}{ Colméias } & \multirow[b]{2}{*}{ Médias } \\
\hline & 1 & 2 & 3 & 4 & 5 & \\
\hline \multirow{15}{*}{ Julho/2000 } & 2,8889 & 0,9144 & 6,1732 & 11,4217 & 0,6880 & 4,42 \\
\hline & 6,5711 & 1,7820 & 3,2194 & 9,0686 & 0,7618 & 4,28 \\
\hline & 6,3582 & 1,4643 & 2,4908 & 6,7010 & 2,1510 & 3,83 \\
\hline & 4,1854 & 0,7321 & 1,3338 & 3,9380 & 1,7727 & 2,39 \\
\hline & 4,7199 & 1,5714 & 3,2860 & 7,0093 & 1,0614 & 3,53 \\
\hline & 3,5663 & 2,5382 & 3,7390 & 7,0358 & 1,3648 & 3,65 \\
\hline & 3,3206 & 3,0415 & 4,2600 & 7,2837 & 1,1750 & 3,82 \\
\hline & 4,4740 & 5,2038 & 5,6245 & 9,1744 & 1,5812 & 5,21 \\
\hline & 4,8824 & 7,5387 & 6,7848 & 8,8293 & 1,3493 & 5,88 \\
\hline & 6,0236 & 12,2636 & 10,5252 & 14,2554 & 2,1076 & 9,04 \\
\hline & 11,8251 & 14,2096 & 11,0540 & 16,2667 & 5,4392 & 11,76 \\
\hline & 4,9027 & 4,0370 & 4,4538 & 7,4470 & 2,7836 & 4,72 \\
\hline & 4,8430 & 9,1000 & 8,5207 & 12,3685 & 7,1171 & 8,39 \\
\hline & 5,0088 & 11,9120 & 9,5822 & 12,9727 & 5,4700 & 8,99 \\
\hline & 6,8767 & 10,8328 & 8,8499 & 15,8350 & 4,7481 & 9,43 \\
\hline Médias & & & & & & 5,26 \\
\hline
\end{tabular}

Observa-se pelos resultados obtidos que as colméias de $A$. mellifera com rainhas ou sem rainhas e com coletores de pólen permanentemente instalados, apresentaram diferenças estatisticamente significativas, com os valores de 7,03 g e 5,26 g em coletas médias diárias de pólen, respectivamente.

Colméias sem rainhas e crias jovens também coletam pólen, porém em menor quantidade do que colméias com rainhas (Al-Tikrity et al., 1972). No entanto, Jeffree \& Allen (1957) verificaram que colmeias sem rainhas, no final do verão nas regiões temperadas, freqüentemente coletam grandes quantidades de pólen.

Delaplane \& Harbo (1987) verificaram que em colméias órfãs a sobrevivência das operárias, o comportamento defensivo e o ganho de peso das colméias sofrem decréscimos significativos. 
4.8 Quantidades (g) de pólen coletado, em colméias de $\boldsymbol{A}$. mellifera com coletores de pólen permanentemente instalados durante 3 meses

Os resultados obtidos para as quantidades (g) de pólen coletado, em colméias de A. mellifera com coletores de pólen permanentemente instalados durante 3 meses encontram-se na Tabela 23.

Tabela 23. Pólen coletado (g) em colméias de A. mellifera com coletores permanentemente instalados, de 19/06/00 a 08/09/00, em Piracicaba, SP.

\begin{tabular}{|c|c|c|c|c|c|c|}
\hline \multirow[b]{2}{*}{ Semanas } & \multicolumn{5}{|c|}{ Colméias } & \multirow[b]{2}{*}{ Médias } \\
\hline & 1 & 2 & 3 & 4 & 5 & \\
\hline 1 & 0,3641 & 11,4765 & 0,2805 & 1,2693 & 5,7097 & 3,8200 \\
\hline 2 & 0,9464 & 28,4076 & 1,1673 & 3,6281 & 16,1348 & 10,0568 \\
\hline 3 & 4,7962 & 24,3113 & 0,6778 & 3,1749 & 12,0333 & 8,9987 \\
\hline 4 & 6,8300 & 33,0666 & 0,7317 & 5,0977 & 10,8546 & 11,3161 \\
\hline 5 & 1,7181 & 6,2912 & 0,4573 & 0,6897 & 0,9754 & 2,0263 \\
\hline 6 & 3,8849 & 10,6366 & 0,2579 & 0,3535 & 0,4648 & 3,1195 \\
\hline 7 & 9,2676 & 36,6983 & 4,0527 & 6,2532 & 4,6829 & 12,1909 \\
\hline 8 & 10,5417 & 46,6487 & 6,5355 & 9,1337 & 8,3241 & 16,2367 \\
\hline 9 & 11,0336 & 28,7463 & 2,9852 & 5,2991 & 5,6209 & 10,7370 \\
\hline 10 & 9,3325 & 28,0615 & 3,0685 & 6,2800 & 1,5998 & 9,6685 \\
\hline 11 & 2,9198 & 25,8630 & 2,2696 & 2,5848 & 0,7815 & 6,8837 \\
\hline 12 & 0,5039 & 22,1979 & 1,8738 & 1,1911 & 0,8258 & 5,3185 \\
\hline
\end{tabular}

Equação da regressão:

$y=-1,1458 x+15,812\left(r^{2}=0,9593\right)$

Em colméias de $A$. mellifera com coletores de pólen permanentemente instalados, de 19/06/00 a 08/09/00, obteve-se média geral de 8,3644 g de pólen (variando de 2,0263 g a $16,2367 \mathrm{~g}$, respectivamente para a quinta e oitava semanas após a instalação dos coletores).

Os resultados obtidos confirmam a afirmação de Eckert et al. (1994) de que nas colméias de $A$. mellifera ocorrem grandes variações nas médias das áreas com pólen durante $o$ ano.

Todd \& Reed (1970) estabeleceram a relação direta entre a quantidade de pólen coletado por uma colônia e as suas quantidades de crias (desoperculadas e operculadas). 
Segundo Hellmich II \& Rothenbuhler (1986) a presença de larvas, neste caso particularmente as maiores, estimulam a coleta de pólen e o seu uso.

\subsection{1 Áreas $\left(\mathrm{cm}^{2}\right)$ com ovos em colméias de $A$. mellifera com coletores de pólen permanentemente instalados durante 3 meses}

Os. resultados obtidos para as áreas $\left(\mathrm{cm}^{2}\right)$ com ovos em colméias de $A$. mellifera com coletores de pólen permanentemente instalados durante 3 meses encontram-se na Tabela 24.

Tabela 24. Áreas $\left(\mathrm{cm}^{2}\right)$ com ovos em colméias de $A$. mellifera com coletores de pólen permanentemente instalados, de 17/06/00 a 09/09/00, em Piracicaba, SP.

\begin{tabular}{|c|c|c|c|c|c|c|}
\hline \multirow[b]{2}{*}{ Datas } & \multicolumn{5}{|c|}{ Colméias } & \multirow[b]{2}{*}{ Médias } \\
\hline & 1 & 2 & 3 & 4 & 5 & \\
\hline $17 / 06 / 00$ & 344 & 520 & 104 & 536 & 696 & 440,00 \\
\hline $01 / 07 / 00$ & 352 & 464 & 96 & 456 & 400 & 353,60 \\
\hline $15 / 07 / 00$ & 296 & 420 & 84 & 380 & 272 & 290,40 \\
\hline $29 / 07 / 00$ & 244 & 388 & 68 & 276 & 160 & 227,20 \\
\hline $12 / 08 / 00$ & 168 & 344 & 56 & 112 & 96 & 155,20 \\
\hline $26 / 08 / 00$ & 104 & 296 & 64 & 72 & 68 & 120,80 \\
\hline $09 / 09 / 00$ & 56 & 320 & 76 & 44 & 48 & 108,80 \\
\hline
\end{tabular}

Equação da regressão:

$y=-4,0673 x+149660\left(r^{2}=0,9639\right)$

As áreas $\left(\mathrm{cm}^{2}\right)$ com ovos sofreram grandes variações ao longo dos 3 meses com coletores de pólen permanentemente instalados.

Essas variações coincidem com os resultados obtidos por Doull (1968) em abelhas européias. Observou que em colméias que receberam suplementação protéica todos os ovos colocados pela rainha transfomaram-se em larvas, enquanto que nas colônias que não receberam suplementação apenas $20 \%$ dos ovos eclodiram.

Cale Jr. (1968) encontrou uma correlação positiva entre a postura da rainha e a coleta de pólen, supondo que a coleta é consequência direta da necessidade protéica das abelhas.

Hellmich II \& Rothenbuhler (1986) afirmaram que a presença de ovos estimulam a 
coleta de pólen.

\subsection{2. Áreas $\left(\mathrm{cm}^{2}\right)$ com crias desoperculadas que darão origem as operárias em colméias de $\boldsymbol{A}$. mellifera com coletores de pólen permanentemente instalados durante 3 meses}

Os resultados obtidos para as áreas $\left(\mathrm{cm}^{2}\right)$ com crias desoperculadas que darão origem as operárias em colméias de $A$. mellifera com coletores de pólen permanentemente instalados durante 3 meses encontram-se na Tabela 25.

Tabela 25. Áreas $\left(\mathrm{cm}^{2}\right)$ com crias desoperculadas que darão origem as operárias em colméias de $A$. mellifera com coletores de pólen permanentemente instalados, de 17/06/00 a 09/09/00, em Piracicaba, SP.

\begin{tabular}{lcccccc}
\hline & \multicolumn{5}{c}{ Colméias } & \\
\cline { 2 - 5 } Datas & 1 & 2 & \multicolumn{1}{c}{3} & 4 & 5 & Médias \\
\hline $17 / 06 / 00$ & 248 & 768 & 12 & 356 & 792 & 435,20 \\
$01 / 07 / 00$ & 224 & 648 & 60 & 312 & 608 & 370,40 \\
$15 / 07 / 00$ & 188 & 672 & 48 & 284 & 544 & 347,20 \\
$29 / 07 / 00$ & 156 & 724 & 80 & 200 & 420 & 316,00 \\
$12 / 08 / 00$ & 132 & 692 & 124 & 144 & 276 & 273,60 \\
$26 / 08 / 00$ & 92 & 612 & 172 & 68 & 132 & 215,20 \\
$09 / 09 / 00$ & 32 & 644 & 236 & 12 & 56 & 196,00 \\
\hline
\end{tabular}

Equação da regressão: $y=-2,8102 x+103543\left(r^{2}=0,9847\right)$

Observa-se pelos resultados que as áreas $\left(\mathrm{cm}^{2}\right)$ de crias desoperculadas que darão origem as operárias apresentaram reduções significativas nos seus valores ao longo das coletas.

Os resultados obtidos confirmam a afirmação de Eckert et al. (1994) de que nas colméias de $A$. mellifera ocorrem grandes variações nas médias das áreas com crias durante $o$ ano. 


\subsection{3 Áreas $\left(\mathrm{cm}^{2}\right)$ com crias operculadas que darão origem as operárias em colméias de A. mellifera com coletores de pólen permanentemente instalados durante 3 meses}

Os resultados obtidos para as áreas $\left(\mathrm{cm}^{2}\right)$ com crias operculadas que darão origem as operárias em colméias de $A$. mellifera com coletores de pólen permanentemente instalados durante 3 meses encontram-se na Tabela 26.

Tabela 26. Áreas $\left(\mathrm{cm}^{2}\right)$ com crias operculadas que darão origem as operárias em colméias de $A$. mellifera com coletores de pólen permanentemente instalados, de 17/06/00 a 09/09/00, em Piracicaba, SP.

\begin{tabular}{lrrrrrr}
\hline & \multicolumn{7}{c}{ Colméias } & \\
\cline { 2 - 6 } Datas & 1 & 2 & \multicolumn{1}{c}{3} & \multicolumn{1}{c}{4} & \multicolumn{1}{c}{5} & Médias \\
\hline $17 / 06 / 00$ & 1076 & 3184 & 336 & 1112 & 1368 & 1415,20 \\
$01 / 07 / 00$ & 896 & 2948 & 300 & 916 & 1056 & 1223,20 \\
$15 / 07 / 00$ & 808 & 2760 & 352 & 756 & 980 & 1131,20 \\
$29 / 07 / 00$ & 756 & 2820 & 476 & 632 & 924 & 1121,60 \\
$12 / 08 / 00$ & 632 & 2632 & 684 & 488 & 844 & 1056,00 \\
$26 / 08 / 00$ & 468 & 2456 & 952 & 392 & 792 & 1012,00 \\
$09 / 09 / 00$ & 280 & 2220 & 1376 & 272 & 772 & 984,00 \\
\hline
\end{tabular}

Equação da regressão:

$y=-4,5694 x+168996\left(x^{2}=0,877\right)$

Observou-se pelos resultados grandes reduções em seus valores ao longo dos 3 meses de coletas de pólen.

Todd \& Reed (1970) estabeleceram a relação direta entre a quantidade de pólen coletado por uma colônia e as suas quantidades de crias (desoperculadas e operculadas).

Segundo Hellmich II \& Rothenbuhler (1986) a presença de larvas estimulam a coleta de pólen e o seu uso, neste caso particularmente as maiores. 


\subsection{4 Áreas $\left(\mathrm{cm}^{2}\right)$ com pólen em colméias de $A$. mellifera com coletores de pólen permanentemente instalados durante 3 meses}

Os resultados obtidos para as áreas $\left(\mathrm{cm}^{2}\right)$ com pólen em colméias de $A$. mellifera com coletores de pólen permanentemente instalados durante 3 meses encontram-se na Tabela 27.

Tabela 27. Áreas $\left(\mathrm{cm}^{2}\right)$ com pólen em colméias de $A$. mellifera com coletores de pólen permanentemente instalados, de 17/06/00 a 09/09/00, em Piracicaba, SP.

\begin{tabular}{lcccccc}
\hline & \multicolumn{7}{c}{ Colméias } & \\
\cline { 2 - 6 } Datas & 1 & 2 & 3 & 4 & 5 & Médias \\
\hline $17 / 06 / 00$ & 628 & 672 & 108 & 268 & 308 & 396,80 \\
$01 / 07 / 00$ & 592 & 588 & 104 & 244 & 280 & 361,60 \\
$15 / 07 / 00$ & 476 & 504 & 96 & 208 & 256 & 308,00 \\
$29 / 07 / 00$ & 364 & 456 & 88 & 192 & 212 & 262,40 \\
$12 / 08 / 00$ & 212 & 372 & 76 & 176 & 168 & 200,80 \\
$26 / 08 / 00$ & 124 & 292 & 68 & 140 & 144 & 153,60 \\
$09 / 09 / 00$ & 28 & 108 & 56 & 100 & 122 & 82,80 \\
\hline
\end{tabular}

Equação da regressão:

$y=-3,7378 x+137562\left(r^{2}=0,9937\right)$

As áreas $\left(\mathrm{cm}^{2}\right)$ com pólen de maneira semelhante aos outros parâmetros avaliados também apresentaram grandes variações nos seus valores ao longo dos 3 meses de coletas de pólen.

Cale Jr. (1968) encontrou uma correlação positiva entre a postura da rainha e a coleta de pólen, supondo que a coleta é consequência direta da necessidade protéica das abelhas.

Hellmich II \& Rothenbuhler (1986) afirmaram que a presença de ovos estimulam a coleta de pólen.

Villeneuve et al. (1988) obtiveram pequena redução $(4,6 \%)$ na produção de mel em colméias com coletores instalados mas não encontraram coeficiente de correlação positivo entre as produções de mel e de pólen das colméias com coletores intermitentemente instalados e as sem coletores. 


\subsection{5 Áreas $\left(\mathrm{cm}^{2}\right)$ com mel em colméias de $A$. mellifera com coletores de pólen permanentemente instalados durante 3 meses}

Os resultados obtidos para as áreas $\left(\mathrm{cm}^{2}\right)$ com mel em colméias de A. mellifera com coletores de pólen permanentemente instalados durante 3 meses encontram na Tabela 28.

Tabela 28. Áreas $\left(\mathrm{cm}^{2}\right)$ com mel em colméias de $A$. mellifera com coletores de pólen permanentemente instalados, de 17/06/00 a 09/09/00, em Piracicaba, SP.

\begin{tabular}{lrrrrrr}
\hline & \multicolumn{7}{c}{ Colméias } & \\
\cline { 2 - 6 } Datas & 1 & 2 & 3 & 4 & 5 & Médias \\
\hline $17 / 06 / 00$ & 1864 & 2028 & 2848 & 736 & 664 & 1628,00 \\
$01 / 07 / 00$ & 1688 & 2168 & 2256 & 612 & 612 & 1467,20 \\
$15 / 07 / 00$ & 1436 & 2388 & 1976 & 564 & 556 & 1384,00 \\
$29 / 07 / 00$ & 1176 & 2240 & 1344 & 492 & 512 & 1152,80 \\
$12 / 08 / 00$ & 864 & 2184 & 612 & 404 & 428 & 898,40 \\
$26 / 08 / 00$ & 620 & 2136 & 196 & 332 & 352 & 727,20 \\
$09 / 09 / 00$ & 344 & 2100 & 36 & 192 & 156 & 565,60 \\
\hline
\end{tabular}

Equação da regressão:

$y=-13,145 x+484009\left(r^{2}=0,9877\right)$

As áreas $\left(\mathrm{cm}^{2}\right)$ com mel de forma semelhante aos outros parâmetros avaliados também apresentaram grandes variações nos seus valores ao longo dos 3 meses de coletas de pólen.

Esses resultados estão de acordo com os verificados por outros autores que notaram uma significativa redução na produção de mel nas colméias com coletores instalados. Tais resultados podem ser observados em: Nelson et al. (1987) de 20\%; Funari et al. (1998e) de 28\%; Lavie (1967) de 24,1\%; Duff \& Furgala (1986b) de 30\% no primeiro ano e $67 \%$ no segundo. No entanto, Bobrzecki \& Wilde $(1990,1991)$ e Vasquez-Romero et al. (1999) não verificaram nenhuma redução na produção de mel em função da instalação dos coletores de pólen. 


\section{CONCLUSÕES}

Foi observada grande variação nas áreas de crias e alimentos entre colméias com coletores de pólen.

Para as análises físico-químicas foram verificadas menores variabilidades nas suas médias e no caso das porcentagens de cinzas não ocorreram variações estatisticamente significativas em nenhum momento do ano.

Ocorreram correlações positivas entre as áreas $\left(\mathrm{cm}^{2}\right)$ com pólen e as áreas com mel, ovos, crias desoperculadas e operculadas que darão origem as operárias. Foram verificadas correlações negativas entre as áreas $\left(\mathrm{cm}^{2}\right)$ com pólen e as áreas com óvulos.

Observou-se correlações positivas entre as áreas $\left(\mathrm{cm}^{2}\right)$ com mel e as áreas com ovos, crias desoperculadas e operculadas que darão origem as operárias. Foram verificadas correlações negativas entre as áreas $\left(\mathrm{cm}^{2}\right)$ com mel e as áreas com óvulos.

As áreas $\left(\mathrm{cm}^{2}\right)$ com crias operculadas que darão origem a zangões apresentaram correlações positivas com as áreas $\left(\mathrm{cm}^{2}\right)$ de crias desoperculadas que darão origem a zangões.

Para as áreas $\left(\mathrm{cm}^{2}\right)$ com óvulos foram verificadas correlações negativas com as áreas $\left(\mathrm{cm}^{2}\right)$ de ovos, crias desoperculadas e operculadas que darão origem as operárias.

Verificou-se para as áreas $\left(\mathrm{cm}^{2}\right)$ crias operculadas que darão origem as operárias correlações positivas com as áreas $\left(\mathrm{cm}^{2}\right)$ de ovos e crias operculadas que darão origem as operárias.

As áreas $\left(\mathrm{cm}^{2}\right)$ de crias desoperculadas que darão origem as operárias apresentaram correlações positivas com as áreas $\left(\mathrm{cm}^{2}\right)$ de ovos.

A eficiência (\%) do coletor de pólen foi decrescente, reduzindo-se a $2 / 3$ da eficiência inicial após 30 dias da sua instalação. 
A maioria do pólen coletado apresentou granulometria maior do $1,00 \mathrm{~mm} / \mu \mathrm{m}$ e menor do que $2,00 \mathrm{~mm} / \mu \mathrm{m}$.

O número médio de abelhas transportando carga de pólen foi maior às 11:00h. em colméias com e sem coletores de pólen permanentemente instalados.

As colméias com rainhas coletaram quantidades de pólen $(\mathrm{g})$ estatisticamente superiores as sem rainhas. 


\section{REFERÊNCIAS BIBLIOGRÁFICAS}

ABOULFARAJ, S.; FURGALA, B. Some effects of the shaparew honey drying ventilator on pollen trapped honey bee (Apis mellifera $\mathrm{L}$.) colonies in East Central Minnesota. American Bee Journal, v.129, n.5, p.333-337, 1989.

AKATSU, I.P.; PEGORARO, A. Influência da largura do tórax de operárias de Apis mellifera scutellata Lepeletier, 1836 (Hym.: Apidae) sobre a eficiência da tela de coletor de pólen instalado em colméias no município de Mandirituba - PR. (compact disc). In: CONGRESSO BRASILEIRO DE APICULTURA, 13., Florianópolis, 2000. Anais. Florianópolis: CBA, 2000.

ALMEIDA-MURADIAN, L.B; PRESOTO, A.E.F. Análise da composição centesimal de pólen apícola desidratado brasileiro. (compact disc). In: CONGRESSO BRASILEIRO DE APICULTURA, 13., Florianópolis, 2000. Anais. Florianópolis: CBA, 2000.

AL-TIKRITY, W.S.; HILLMANN, R.C. A new instrument for brood measurement in a honey bee colony. American Bee Journal, v.26, n.1, p.20-21, 1971.

AL-TIKRITY, W.S.; BENTON, A.W.; HILLMAN, R.C.; CLARKE Jr., W.W. The relationship between the amount of unsealed brood in honeybee colonies and their pollen collection. Journal of Apicultural Research, v.11, n.1, p. 9-12, 1972.

ALVES, M.L.T.M.F.; MORETI, A.C.C.C.; SILVA, E.C.A.; SANTOS, E.A.; SILVA, R.M.B. Observações sobre o pólen coletado por colônias de abelhas africanizadas (Apis mellifera) (Hymenoptera, Apidae). In: CONGRESSO 
BRASILEIRO DE APICULTURA, 10., Pousada do Rio Quente, 1994. Anais. Pousada do Rio Quente: CBA, 1994. p350-351.

ALVES, M.L.T.M.F; MORETI, A.C.C.C; SILVA, E.C.A da.; SILVA, R.M.B da.; TEIXEIRA, E.W.; OTSUK, I.P. Quantidade diária de pólen coletado por abelhas africanizadas (Apis mellifera L.) usando diferentes modelos de coletores. Boletim da Indústria Animal, v. 54, n.1, p.93-98, 1997.

AVILA, O. La miel, el polen y la jalea real. 2.ed. Barcelona: Ed. CEDEL, 1980. 168 p.

BARKER, R.J. The influence of food inside the hive on pollen collection by a honeybee colony. Journal of Apicultural Research, v.10, n.1, p.23-26, 1971.

BARRETO, L.M.R.C.; RABELO, P.C.; BELÉZIA, C.O. Perfil protěico do pólen coletado por Apis mellifera L. (hibrida africanizada) no período outono - inverno no apiário do centro de estudos apícolas da Universidade de Taubaté. (compact disc). In: CONGRESSO BRASILEIRO DE APICULTURA, 13., Florianópolis, 2000. Anais. Florianópolis: CBA, 2000.

BARTH, O.M. O pólen no mel brasileiro. Rio de Janeiro: Gráfica Luxor, 1989. $150 \mathrm{p}$.

BLASCHON; B.; GUTTENBERGER, H.; HRASSNIGG, N.; CRAILSHEIM, $\mathrm{K}$. Impact of bad weather on the development of the broodnest and pollen stores in a honeybee colony (Hymenoptera: Apidae). Entomologia Generalis, v.24, n.1, p.49-60, 1999.

BOBRZECKI, J.; WILDE, J. The influence of pollen trapping upon the development and productivity of weak and strong honeybee colonies. In: INTERNATIONAL CONGRESS OF APICULTURE, 31., Varsóvia, 1987. Proceedings. Bucharest: Apimondia, p.421-424. Resumo 994/90 em Apicultural Abstracts, v.41, n.3, p.270, 1990.

BOBRZECKI, J.; WILDE, J. Effect of pollen trapping on the development of honeybee colonies. Acta Academiae Agriculturae ac Technicae 
Olstenensis, Zootechnica, n.32, p.253-262, 1989. Resumo 1070/91 em Apicultural Abstracts, v.42, n.3, p.274, 1991.

BOELTER, A.M; WILSON, W.T. Attempts to condition the pollen preference of honey bees. American Bee Journal, v.124, n.8, p.609-610, 1984.

BRASIL. Portaria n. 25, de 31 de julho de 2000. Diário Oficial, 04 de ago. 2000. Seção 1, p.9-10. Regulamento técnico de identidade e qualidade de pólen apícola.

CALE Jr., G.H. Pollen gathering relationship to honey collection and egg laying in honey bees. American Bee Journal, v. 108, n. 1, p.08-09, 1968.

CAMARGO, O.A. de; MONIZ, A.C.; JORGE, J.A.; VALADARES, J.M.A.S. Métodos de análise química, mineralógica e física de solos do Instituto Agronômico de Campinas. Campinas: IAC, 1986. 94p. (IAC. Boletim Técnico, 106).

CORNEJO, L. Polen: tecnologia de su producción, procesado y ingerircializacion. Buenos Aires: Editorial Iptea, 1994.

COSTA, F.M.; TORAL, F.L.B.; ALVES, A.F.; ALBUQUERQUE, K.P.; FRITZEN, A.E.T.; RUVOLO-TAKASUSUKI, M.C.C.; TOLEDO, V.A.A. Características produtivas e reprodutivas de colônias de Apis mellifera submetidas à alimentação natural na região de Maringá - PR. (compact disc). In: CONGRESSO BRASILEIRO DE APICULTURA, 13., Florianópolis, 2000. Anais. Florianópolis: CBA, 2000.

CRAILSHEIM, K. The protein balance of the honey bee worker. Apidologie, v.21, p.417-429, 1990.

CRAILSHEIM, K.; SCHNEIDER, L.H.W.; HRASSNIGG, N.; BÜHLMANN, G.; BROSCH, U.; GMEINBAUER, R.; SCHÖFFMANN, B. Pollen consumption and utilization in worker honeybees (Apis mellifera carnica): dependence on individual age and function. Journal of Insect Physiology, v.38, n.6, p.409-419, 1992. 
CRANE, E. Bees and beekeeping: science, practice and world resources. Oxford: Heinemann Newnes, 1990. 614p.

CRUZ-LANDIM, C. de. Avaliação fotográfica de digestão do pólen presente no intestino de operárias de Apis mellifera L. (Hymenoptera, Apidae). Naturalia, v.10, p.27-36, 1985.

DÁVILA, M.; USCA, J.; AGUIAR, P.F. Estudio comparativo de ocho modelos de trampas para polen. Revista Peruana de Entomologia, v.19, n.1, p.6066, 1976.

DAY, S.; BEYER, R.; MERCER, A.; OGDEN, S. The nutrient composition of honeybee-collected pollen in Otago, New Zealand. Journal of Apicultural Research, v.29, n.3, p.138-146, 1990.

DELAPLANE, K.S.; HARBO, J.R. Effect of queenlessness on worker survival, honey gain and defence behaviour in honeybees. Journal of Apicultural Research, v.26, n.1, p.37-42, 1987.

DELL'ISOLA, M.M. Apicultura racional. Buenos Aires: Selo Argentino, 1945. 237p.

DIETZ, A. The hive and the honey bee. Hamilton: Dadant and Sons, 1975. cap. 5: p. 125-156: Nutrition of the adult honey bee.

DIETZ, A. Polen and honey bee nutrition. Gleanings in Bee Culture, v.107, n.7, p.366-368, 1979.

DIETZ, A.; LAMBREMONT, E.N. Caste determination in honey bees II. Annals of the Entomological Society of America, v.63, n.5, p.1342-1345, 1970.

DOULL, K.M. Nuevas investigaciones acerca de los substitutos del polen. Apiacta, v.2, n.1, p.14-17, 1968.

DOULL, K.M. Relationships between consumption of pollen supplement, honey production and broodrearing on colonies of honeybees Apis mellifera L. I. Apidologie, v.11, p.361-365, 1980. 
DRELLER, C.; PAGE Jr., R.E.; FONDRK, M.K. Regulation of pollen foraging in honeybee colonies: effects of young brood, stored pollen, and empty espace. Behavioral Ecology and Sociobiology, v.45, n.3-4, p.227-233, 1999.

DUFF, S.R.; FURGALA, B. Pollen trapping honey bee colonies in Minnesota. Part I: Effect on amount of trapped, brood, reared, winter survival, queen longevity, and adult bee population. American Bee Journal, v.126, n.10, p.686-689, 1986a.

DUFF, S.R.; FURGALA, B. Pollen trapping honey bee colonies in Minnesota. Part II: Effect on foraging activity, honey production, honey moisture content, and nitrogen content of adult workers. American Bee Journal, v.126, n.11, p.755-758, 1986 b.

ECHEVERRY, J.D.; JORDAN, B. Pollen collection techniques with Africanized bees in tropical and subtropical regions using the TTA (Tropical Africanized Type). In: INTERNATIONAL CONGRESS OF APICULTURE, 33., Rio de Janeiro, 1989. Proceedings. Bucharest: Apimondia, s.d. p.454-457.

ECKERT, C.D.; WINSTON, M.L.; YDENBERG, R.C. The relationship between population size, amount of brood, and individual foraging behaviour in the honey bee, Apis mellifera L. Oecologia, v.97, p.248-255, 1994.

FEWELL, J.H.; WINSTON, M.L. Colony state and regulation of pollen foraging in the honey bee, Apis mellifera L. Behavioral Ecology and Sociobiology, v.30, p.387-393, 1992.

FREE, J.B. Factors determining the collection of pollen by honey bee foragers. Animal Behaviour, v.15, n.1, p. 134-144, 1967.

FREE, J.B. Managing honeybee colonies to enhance the pollen-gathering stimulus from brood pheromones. Applied Animal Ethology, v.5, p.173178, 1979. 
FREE, J.B. A organização social das abelhas (Apis). São Paulo: EDUSP, 1980. 78p. (Temas de Biologia, 13).

FREE, J.B. Insect Pollination of Crops. 2 ed. London: Academic Press, 1993. $684 p$.

FREE, J.B.; WILLIAMS, I.H. Factors determining the rejection of drones by the honey bee colony. Animal Behaviour, v.23, n.3, p.650-675, 1975.

FUNARI, S.R.C.; BAUAB-VIANNA, M.J.; CURI, P.R.; FUNARI, A.R.M. Avaliação da contribuição individual da abelha africanizada Apis mellifera na produtividade da colmeia. Veterinária e Zootecnia; v.5, p.9-16, 1993.

FUNARI, S.R.C.; ROCHA, H.C.; SFORCIN, J.M. Composição bromatológica e mineral do pólen coletado por abelhas africanizadas Apis mellifera L. na região de Botucatu (SP). In: REUNIÃO DA SOCIEDADE BRASILEIRA DE ZOOTECNIA, 35., Botucatu, 1998. Anais. Botucatu: SBZ, 1998a. p.522-524.

FUNARI, S.R.C.; ROCHA, H.C.; SFORCIN, J.M. Composição bromatológica de pupas e coleta de pólen em colônias de abelhas africanizadas Apis mellifera L. In: REUNIÃO DA SOCIEDADE BRASILEIRA DE ZOOTECNIA, 35., Botucatu, 1998. Anais. Botucatu: SBZ, 1998b. p.555557.

FUNARI, S.R.C.; ROCHA, H.C.; SFORCIN, J.M. Coleta de pólen e desenvolvimento de colônias de abelhas africanizadas (Apis mellifera $\mathrm{L}$.). In: REUNIÃO DA SOCIEDADE BRASILEIRA DE ZOOTECNIA, 35., Botucatu, 1998. Anais. Botucatu: SBZ, 1998c. p.552-554.

FUNARI, S.R.C.; ROCHA, H.C.; FERNANDES Jr, A.; SFORCIN, J.M. Número de bactérias em função do método de secagem do pólen. In: REUNIÃO DA SOCIEDADE BRASILEIRA DE ZOOTECNIA, 35., Botucatu, 1998. Anais. Botucatu: SBZ, 1998d. p.525-527.

FUNARI, S.R.C.; ROCHA, H.C.; SFORCIN, J.M.; CURI, P.R.; PEROSA, J.M.Y. Coleta de pólen e produção de mel e própolis em colônias de abelhas 
africanizadas (Apis mellifera L.). Boletim da Indústria Animal, v.55, n.2, p.189-193, 1998e.

GRANT, V. The flower constancy of bees. Botanical Review, v.16, n.17, p.379-398, 1950.

HARBO, J.R. Effect of population size on brood production, worker survival and honey gain in colonies of honeybees. Journal of Apicultural Research, v.25, n.1, p.22-29, 1986.

HARBO, J.R. Effect of brood rearing on honey consumption and the survival of worker honey bees. Journal of Apicultural Research, v.32, n.1, p.11-17, 1993.

HAYDAK, M.K. Nitrogen content of imago the worker honey bee. Journal of Agricultural Research, v.49, n. 1, p.21-27, 1934.

HAYDAK, M.K. Alimentacion de las abejas y los substitutos del polen. Apiacta, v.1, n.1, p.1-3, 1967.

HAYDAK, M.H. Honey bee nutrition. Annual Review of Entomology, v.15, p.143-156, 1970.

HELLMICH II, R.L.; KULINCEVIC, J.M.; ROTHENBUHLER, W.C. Selection for high and low pollen-hoarding honey bees. The Journal of Heredity, v.76, n.3, p.155-158, 1985.

HELLMICH II, R.L.; ROTHENBUHLER, W.C. Pollen hoarding and use by high and low pollen-hoarding honeybees during the course of brood rearing. Journal of Apicultural Research, v.25, n.1, p.30-34, 1986.

HERBERT Jr., E.W.; SHIMANUKI, H. Chemical composition and nutritive value of bee-collected and bee-stored pollen. Apidologie, v.9, n. 1, p.33-40, 1978.

HERBERT Jr., E.W.; SHIMANUKI, H. An evaluation of seven potential pollen substitutes for honey bees. American Bee Journal, v.120, n.5, p.349-350, 1980. 
HERBERT Jr., E.W., MILLER-IHLI, N.J. Seasonal variation of seven minerals in honey bee collected pollen. American Bee Journal, v.127, n.5, p.367$369,1987$.

HERBERT Jr., E.W.; SHIMANUKI, H.; CARON, D. Optimum protein levels required by honey bees (Hymenoptera: Apidae) to initiate and maintain brood rearing. Apidologie, v.8, n.2, p.141-146, 1977.

HOUSE, H.L. Insect nutrition. Annual Review of Entomology, v.6, p.13-26, 1961.

IANNUZZI, J. Pollen trapping for "beeginners": trap purchase. American Bee Journal, v. 132, n.8, p.522-524, 1992.

IMPERATRIZ-FONSECA, V.L.; RAMALHO, M.; KLEINERTGIOVANNINI, A. Abelhas sociais e flores - Análise polínica como método de estudo. In: PIRANI, J.R.; CORTOPASSI-LAURINO, M. (Coord.) Flores e abelhas em São Paulo. São Paulo: EDUSP, 1993. cap.1, p. 17-30.

JAYCOX, R.E. Honey bee queen pheromones and worker foraging behavior. Annals of the Entomological Society of America, v.63, n.1, p.222-228, 1970.

JEFFREE, E.P.; ALLEN, M.D. The annual cycle of pollen storage by honey bees. Journal of Economic Entomology, v.50, n.2, p.211-212, 1957.

KEVAN, P.G; BAKER, H.G. Insects as flower visitors and pollinators. Annual Rewiew of Entomology, v.28, p.407-453, 1983.

KOENIGER, N.; VEITH, H.J. Spezifität eines brutpheromons und bruterkennung bei der honigbiene (Apis mellifera). Apidologie, v.15, n.2, p.205-210, 1984.

LAVIE, P. Influence de l'utilisation du piège a pollen sur le rendement en miel des colonies d'abeilles. Annales de l'Abeille, v.10, n.2, p.83-95, 1967.

LEE, P.C.; WINSTON, M.L. Effects of reproductive timing and colony size on the survival, offspring colony size and drone production in the honey bee (Apis mellifera). Ecological Entomology, v.12, p.187-195, 1987. 
LEVIN, M.D.; LOPER, G.M. Factors affecting pollen trap efficiency. American Bee Journal, v. 124, n. 10, p.721-723, 1984.

LOKEN, A. Flower visiting insects and their importance as pollinators. Bee World, v.64, n.4, p.130-140, 1981.

LOPER, G.M; COHEN, C.A. Aminoacid content of dandelion pollen, a honey bee (Hymenoptera: Apidae) nutritional evaluation. Journal of Economic Entomology, v.80, n.1, p.14-17, 1987.

MACKENSEN, O; NYE, W.P. Selecting and breeding honeybees for collection alfalfa pollen. Journal of Apicultural Research, v.5, n.2, p.7986, 1966.

MATSUKA, M.; WATABE, N.; TAKEUCHI, K. Analysis of the food of larval drone honeybees. Journal of Apicultural Research, v.12, n.1, p.0307, 1973.

McLELLAN, A.R. Some effects of pollen traps on colonies of honeybees. Journal of Apicultural Research, v.13, n.2, p.143-148, 1974.

MICHENER, C.D.; WINSTON, M.L.; JANDER, R. Pollen manipulation and related activities in bees of de family Apidae. University of Kansas Sciense Bulletin, v. 51, p.575-601, 1978.

MOKRASCH, L.C. Analysis of hexose phosphates and sugar mixtures with the anthrone reagent. Journal of Biological Chemistry, v.208, n.1, p.55-59, 1954.

MOORE, P.D; WEBB, J.A.; COLLINSON, M.E. Pollen analysis. London: Blackwell Science, 1991. 216p.

MORSE, R; HOOPER, T. Enciclopédia de apicultura ilustrada. Lisboa: Publicações Europa América, 1986. v.1. (Coleção Euroagro, 17).

MOTTER, M. Alfalfa seed production in the San Joaquin Valley, California. Bee World, v.62, n.3, p.111-114, 1981.

NEIRA, M. Coleta y uso del pólen por las abejas (Apis mellifera L. Hymenoptera: Apidae). In: SEEEMANN, P.; NEIRA, M. (Ed.) Tecnologia 
de la producción apícola. Valdivia: Universidad Austral de Chile, Instituto de Producción Y Sanidad Vegetal, 1988. p.76-94.

NELSON, D.L.; McKENNA, D.; ZUMWALT, E. The effect of continuous pollen trapping on sealed brood, honey production and gross income in Northern Alberta. American Bee Journal, v. 127, n.9, p.648-650, 1987.

NEUMAIER, R.; LENGLER, S. Efeito da precipitação e temperatura do ar na produção de pólen em apiário coberto em colmeias de abelhas africanizadas. In: CONGRESSO BRASILEIRO DE APICULTURA, 12., Salvador, 1998. Anais. Salvador: CBA, 1998a. p.228.

NEUMAIER, R.; LENGLER, S. Efeito da umidade relativa do ar na produção de pólen em apiário coberto em colmeias de abelhas africanizadas. In: CONGRESSO BRASILEIRO DE APICULTURA, 12., Salvador, 1998. Anais. Salvador: CBA, 1998b. p.228.

NIELSEN, N.; GRÖMMER, J; LUNDÉN, R. Investigation on the chemical composition of pollen from some plants. Acta Chemica Scandinavica, v.9, n.7, p.1100-1106, 1955.

NOGUEIRA-NETO, P. Vida e criação das abelhas indígenas sem ferrão. 2.ed. São Paulo: Nogueirapis, 1997. 445p.

NYE, W.P.; MACKENSEN, O. Selective breeding of honeybees for alfalfa pollen collection: with tests in high and low alfalfa pollen collection regions. Journal of Apicultural Research, v.9, n.2, p.61-64, 1970.

OCHOA, C.A. El polen: recogida, manejo y aplicaciones. Hojas Divulgadoras, v. 8, n. $80,16 \mathrm{p} ., 1980$.

PANKIW, T.; PAGE Jr., R.E.; FONDRK, M.K. Brood pheromone stimulates pollen foraging in honey bees (Apis mellifera). Behavioral Ecology and Sociobiology, v.44, p.193-198, 1998.

PENG, Y.S.; MEDHAT, J.; MARSTON, M; FANG, Y. The digestion of dandelion pollen by adult worker honeybees. Physiological Entomology, v.10, n.1, p.75-82, 1985. 
PREGNOLATO, W.; PREGNOLATO, N.P. (Coord.). Normas analíticas do Instituto Adolfo Lutz. (v.1: Métodos químicos e físicos para análise de alimentos). 3.ed. São Paulo: Instituto Adolfo Lutz, 1985. 533p.

PROST, J.P. Apicultura. Madrid: Mundi - Prensa, 1981, 520p.

ROOT, A.I. ABC y XYZ de la apicultura. 7.ed. Buenos Aires: Lib. Hachete, 1965. 700p.

SAMPAIO, E.A.B. Caracterização do pólen apícola, processado ingerircial e armazenado na colmeia - pão de abelhas, de algumas localidades do Paraná. Curitiba, 1991. 118p. (Mestrado) - Universidade Federal do Paraná.

SAS INSTITUTE. SAS/STAT software: changes and enhancements through release 6.12. Cary, 1997.

SCHMIDT, J.O. Phagostimulants in pollen. Journal of Apicultural Research, v. 24, n. 2, p. $107-114,1985$.

SCHMIDT, J.O.; BUCHMANN, S.L. Pollen digestion and nitrogen utilization by Apis mellifera L. (Hymenoptera: Apidae). Comparative Biochemistry and Physiology, v.82A, n.3, p.499-503, 1985.

SCHMIDT, J.O; THOENES, S.C.; LEVIN, M.D. Survival of honey bees, Apis mellifera (Hymenoptera: Apidae), fed various pollen sources. Annals of the Entomological Society of America, v.80, n.2, p.176-183, 1987.

SHAWER, M.B. Major pollen sources in Kafr El-Sheikh, Egypt, and the effect of pollen supply on brood area and honey yield. Journal of Apicultural Research, v.26, n.1, p.43-46, 1987.

SHUEL, R.W.; DIXON, S.E. Studies on the mode of action of royal jelly in honeybee development. II. Respiration of newly emerged larvae on various substrates. Canadian Journal of Zoology, v.37, n.5, p. 803-813, 1959.

SINGH, S.; SAINI, K.; JAIN, K.L. Quantitative comparison of lipids in some pollens and their phagostimulatory effects in honey bees. Journal of Apicultural Research, v.38, n.1-2, p.87-92, 1999. 
STANLEY, R.; LINSKENS, $H$. Pollen: biology, biochemistry and management. Heidilberg: Springer - Verlag, 1974. 307p.

SZOLDERITS, M.J.; CRAILSHEIM, K. A comparison of pollen consumption and digestion in honeybee (Apis mellifera carnica) drones and workers. Journal of Insect Physiology, v.39, n.10, p.877-881, 1993.

THORP, R.W. Structural behavioral and physiological adaptation of bee (Apoidea) for collecting pollen. Annals of the Missouri Botanical Garden, v.66, p.788-812, 1979.

TODD, F.E.; BRETHERICK, $O$. The composition of pollens. Journal of Economic Entomology, v.35, n.3, p.312-317, 1942.

TODD, F.E.; REED, C.B. Brood measurement as a valid index to the value of honey bees as pollinatiors. Journal of Economic Entomology, v.63, n.1, p. 148-149, 1970.

TREVISAN, M. O pólen. Informe Agropecuário, v.9, n. 106, p.52-55, 1983.

VAN ASS, C.; ROCHA, H.C.; LARA, A.A.; SUZANA, J. Composição mineral de pupas de abelhas africanizadas em colônias submetidas à produção de pólen. (compact disc). In: CONGRESSO BRASILEIRO DE APICULTURA, 13., Florianópolis, 2000. Anais. Florianópolis: CBA, 2000.

VASQUEZ-ROMERO, R.E.; HERMANDEZ-VALERO, E.J.; TELLODURAN, J.E. Efficiency of trapping of two commercial pollen traps and some determining factors that impact on the pollen compilation by bees. In: INTERNATIONAL CONGRESS OF APICULTURE, 36., Vancouver, 1999. Proceedings. Bucharest: Apimondia, s.d., p. 242.

VILLENEUVE, J.L.; HOULE, E.; LABONTÉ, J. Pollen trapping versus honey production field report. American Bee Journal, v.128, n.9, p.612-613,641, 1988.

VIVINO, A.E.; PALMER, L.S. The chemical composition and nutritional value of pollens collected by bees. Archives of Biochemistry, v.4, p.129-136, 1944. 
VORST, E. van der; MATTYS, J.; RYCKE, P.H. de; JACOBS, F.J. Comparative lipid composition of colony - and laboratory - stored pollen. Journal of Apicultural Research, v.21, n.3, p. 174-177, 1982.

WALLER, D.G.; CARON, M.D.; LOPER, M.G. Pollen patties maintain brood rearing when pollen is trapped from honey bee colonies. American Bee Journal, v.121, n.2, p.101-106, 1981.

WESTCOTT, L.C.; WINSTON, M.L. Chemical acaricides in Apis mellifera (Hymenoptera: Apidae) colonies; do they cause nonlethal effects? The Canadian Entomologist, v.131, n.3, p.363-371, 1999.

WINSTON, M.L. The biology of the honey bee. Cambridge: Harvard University Press, 1987. 281p.

YOUSSEF, A.M; FARAG, R.S.; EWIES, M.A; El-SHAKAA, S.M.A. Chemical studies on pollen collected by honeybees in Giza region, Egypt. Journal of Apicultural Research, v. 17, n.3, p.110-113, 1978. 